\title{
L-Tryptophan Induces a Marine-Derived Fungus Fusarium sp. L1 to Produce Indole Alkaloids with Activity against the Zika Virus
}

Yong-Wei Guo,,$\stackrel{\S}{\S}$ Xiao-Jing Liu, ${ }^{\dagger}$ Jie Yuan," Hou-Jin Li, ${ }^{\ddagger}$ Taifo Mahmud, ${ }^{\perp}$ Ming-Jun Hong, ${ }^{\dagger} \quad$ Jian-Chen Yu, $"$ and Wen-Jian Lan ${ }^{\dagger, *}$

†School of Pharmaceutical Sciences, Sun Yat-sen University, Guangzhou 510006, China

${ }^{\sharp}$ School of Chemistry, Sun Yat-sen University, Guangzhou 510275, China

${ }^{\S}$ School of Marine Sciences, Sun Yat-sen University, Guangzhou 510275, China

"Zhongshan School of Medicine, Sun Yat-sen University, Guangzhou 510080, China

${ }^{\perp}$ Department of Pharmaceutical Sciences, Oregon State University, Corvallis, Oregon 97331, USA 


\section{Table of Contents}

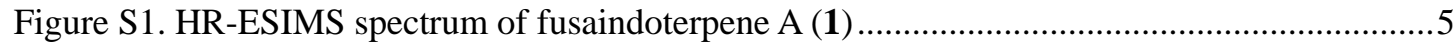

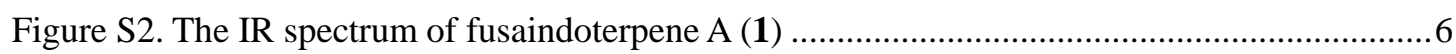

Figure S3. ${ }^{1} \mathrm{H}$ NMR spectrum of fusaindoterpene $\mathrm{A}(\mathbf{1})$ in $\mathrm{CDCl}_{3}(400 \mathrm{MHz}) \ldots \ldots \ldots \ldots \ldots \ldots \ldots \ldots \ldots \ldots \ldots . . .7$

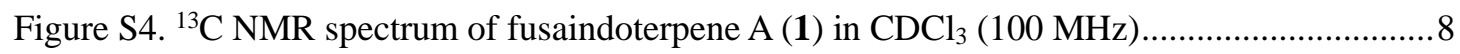

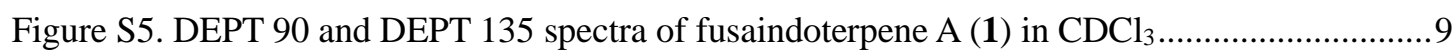

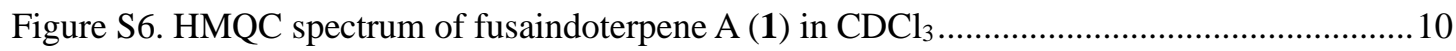

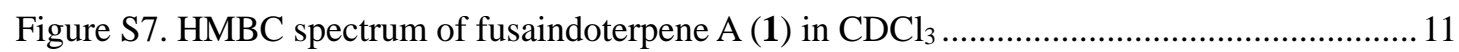

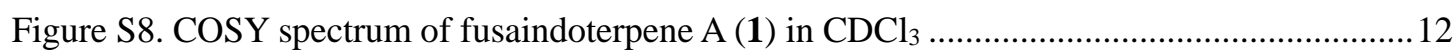

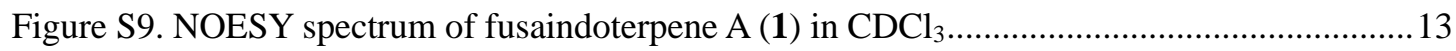

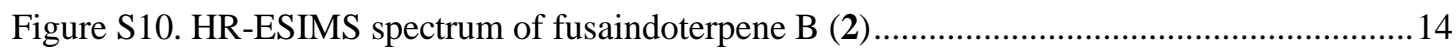

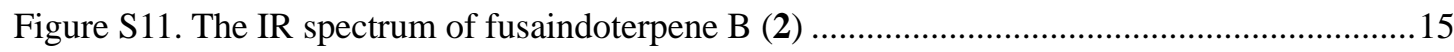

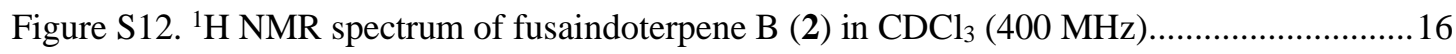

Figure S13. ${ }^{13} \mathrm{C}$ NMR spectrum of fusaindoterpene $\mathrm{B}(2)$ in $\mathrm{CDCl}_{3}(100 \mathrm{MHz}) \ldots \ldots \ldots \ldots \ldots \ldots \ldots \ldots . . . . . .17$

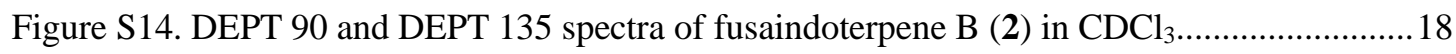

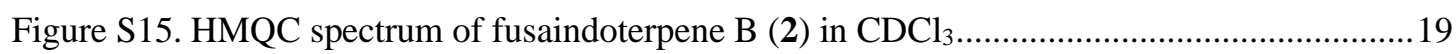

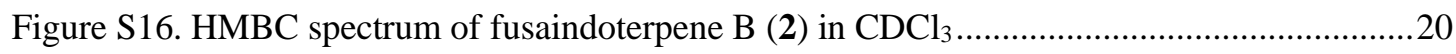

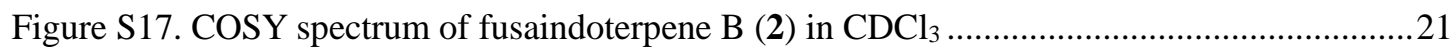

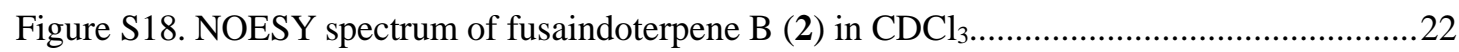

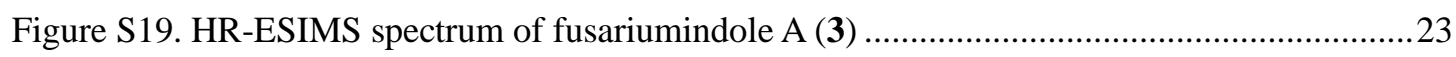

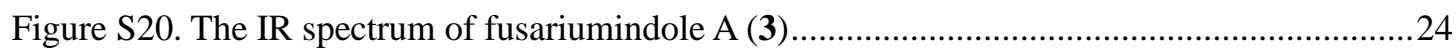

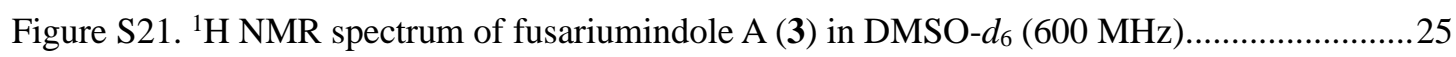

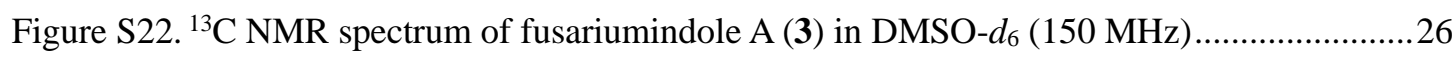

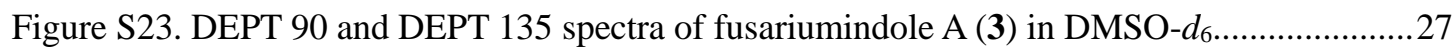

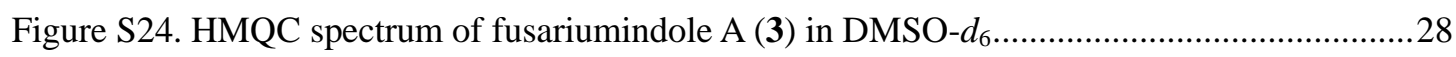

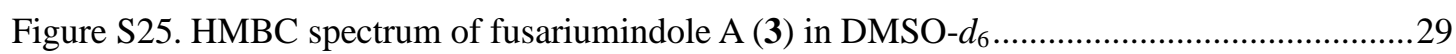

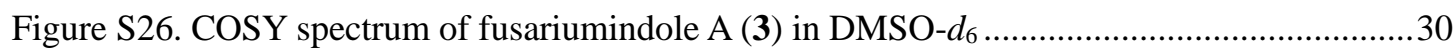

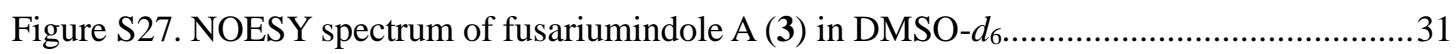

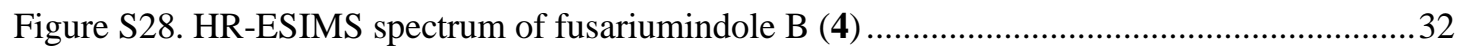

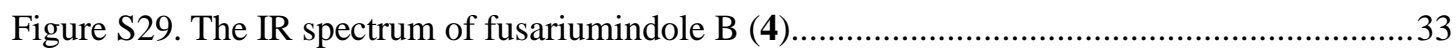

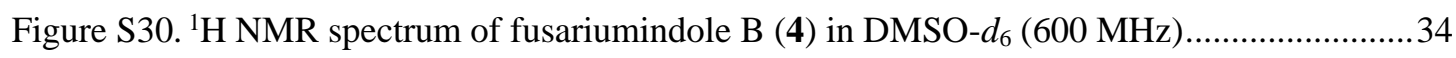

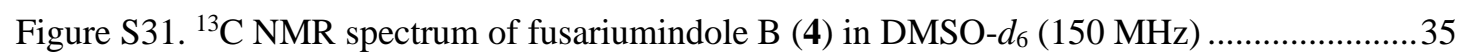

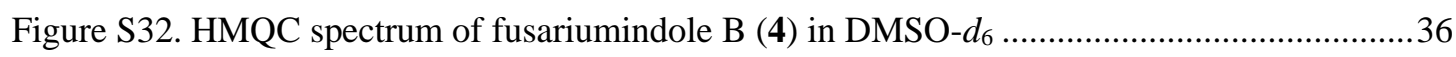

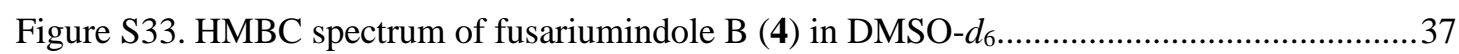

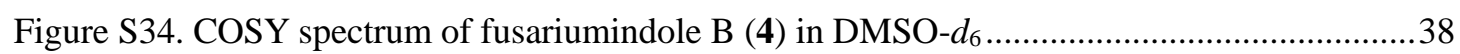

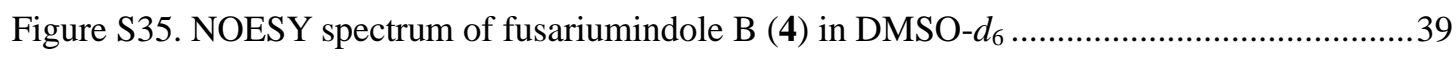

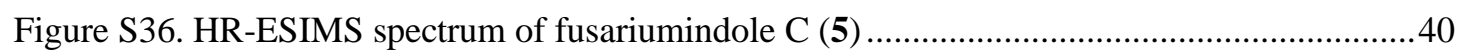

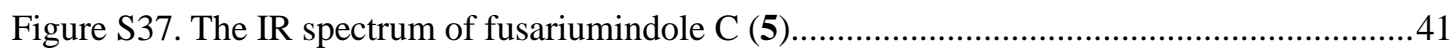

Figure S38. ${ }^{1} \mathrm{H}$ NMR spectrum of fusariumindole C (5) in DMSO- $d_{6}(400 \mathrm{MHz})$..........................4.

Figure S39. ${ }^{13} \mathrm{C}$ NMR spectrum of fusariumindole C (5) in DMSO- $d_{6}(100 \mathrm{MHz}) \ldots \ldots \ldots \ldots \ldots \ldots \ldots . . .43$

Figure S40. DEPT 90 and DEPT 135 spectra of fusariumindole C (5) in DMSO- $d_{6} \ldots \ldots \ldots \ldots \ldots \ldots \ldots . . . .44$

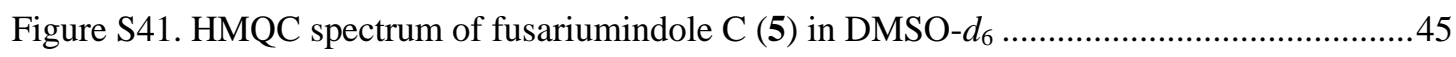

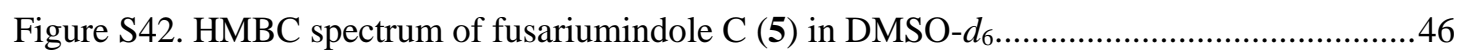


Figure S43. COSY spectrum of fusariumindole C (5) in DMSO- $d_{6}$ 47

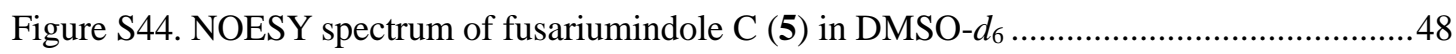

Figure S45. HR-ESIMS spectrum of $( \pm)$-isoalternatine A $(6)$.............................................49

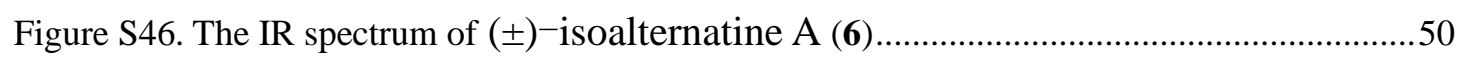

Figure S47. ${ }^{1} \mathrm{H}$ NMR spectrum of $( \pm)$-isoalternatine $\mathrm{A}(\mathbf{6})$ in $\mathrm{CDCl}_{3}(400 \mathrm{MHz})$...................51

Figure S48. ${ }^{13} \mathrm{C}$ NMR spectrum of $( \pm)$-isoalternatine $\mathrm{A}$ 6) in $\mathrm{CDCl}_{3}(100 \mathrm{MHz})$..................52

Figure S49. DEPT 90 and DEPT 135 spectra of $( \pm)$-isoalternatine $\mathrm{A}(\mathbf{6})$ in $\mathrm{CDCl}_{3} \ldots \ldots \ldots \ldots . . . . . .53$

Figure S50. HMQC spectrum of $( \pm)$-isoalternatine $\mathrm{A}(\mathbf{6})$ in $\mathrm{CDCl}_{3}$...................................54

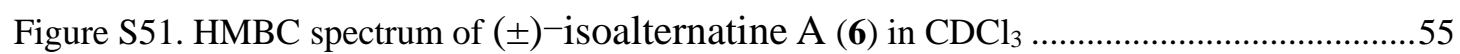

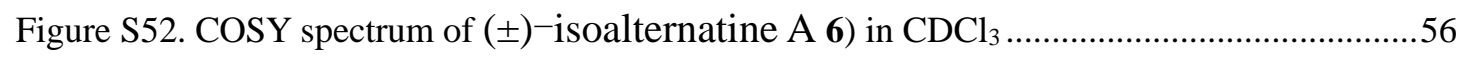

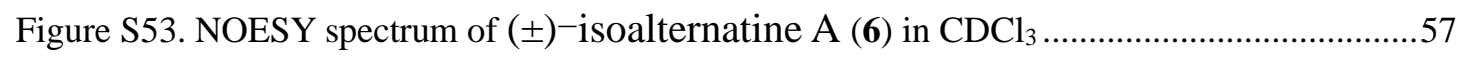

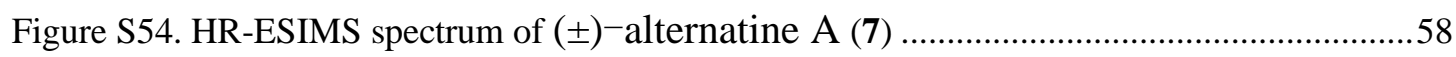

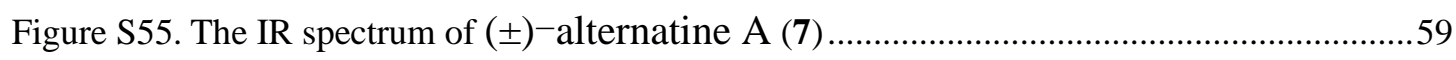

Figure S56. ${ }^{1} \mathrm{H}$ NMR spectrum of $( \pm)$-alternatine A $(7)$ in $\mathrm{CDCl}_{3}(400 \mathrm{MHz})$......................60

Figure S57. ${ }^{13} \mathrm{C}$ NMR spectrum of $( \pm)$-alternatine $\mathrm{A}(7)$ in $\mathrm{CDCl}_{3}(100 \mathrm{MHz})$......................61

Figure S58. DEPT 90 and DEPT 135 spectra of $( \pm)$-alternatine $\mathrm{A}(7)$ in $\mathrm{CDCl}_{3} \ldots \ldots \ldots \ldots \ldots \ldots . . . . . . . .62$

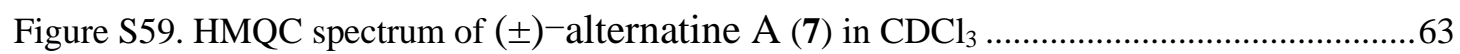

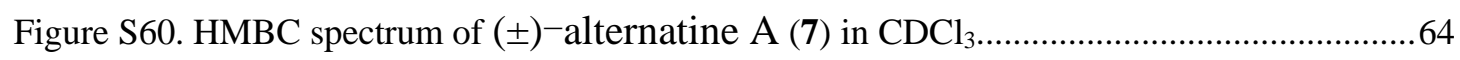

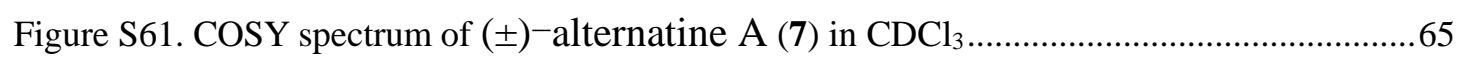

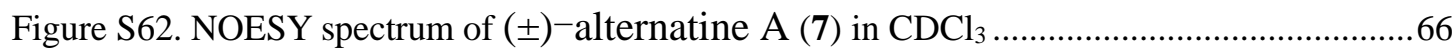

Figure S65. ${ }^{1} \mathrm{H}$ NMR spectrum of 8 in $\mathrm{CDCl}_{3}(400 \mathrm{MHz})$....................................................67

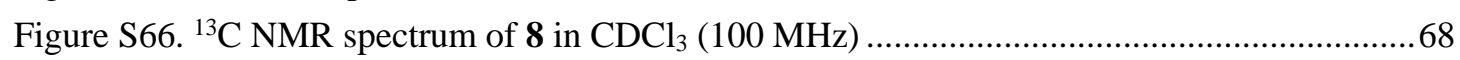

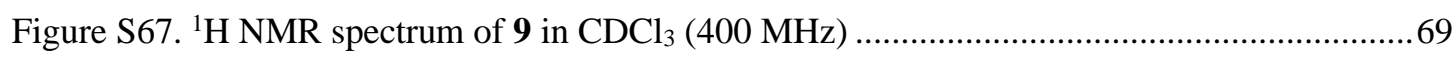

Figure S68. ${ }^{13} \mathrm{C}$ NMR spectrum of 9 in $\mathrm{CDCl}_{3}(100 \mathrm{MHz})$.......................................................70

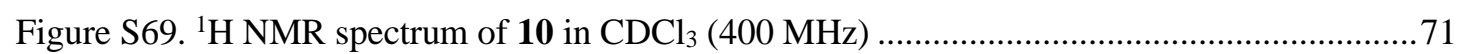

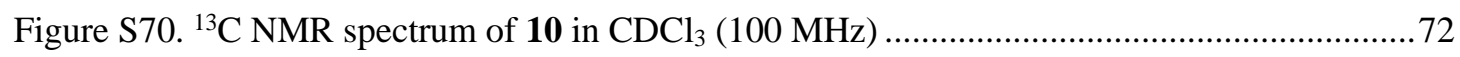

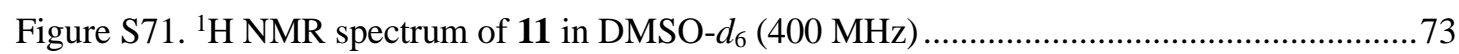

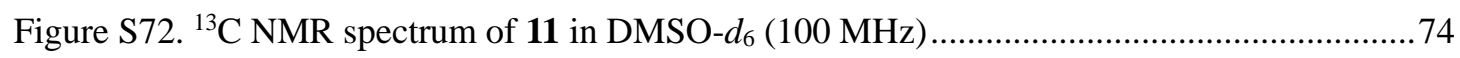

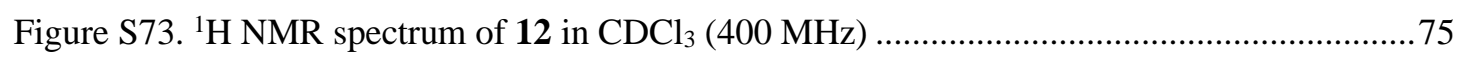

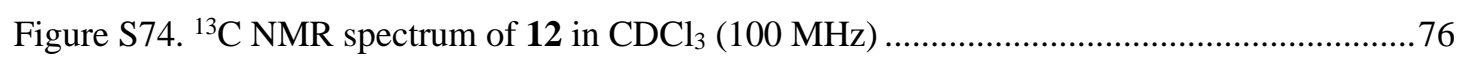

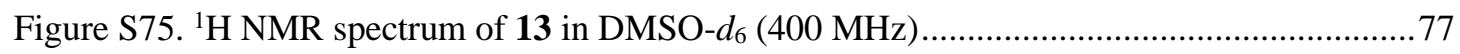

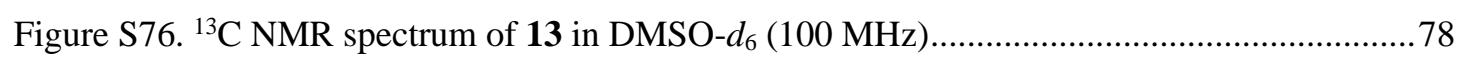

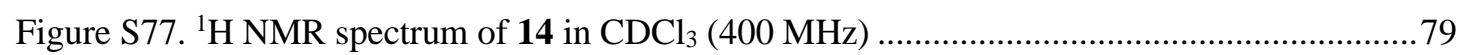

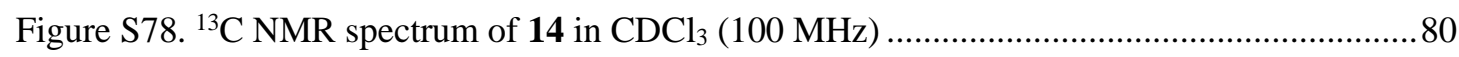

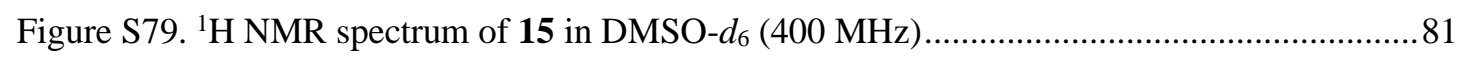

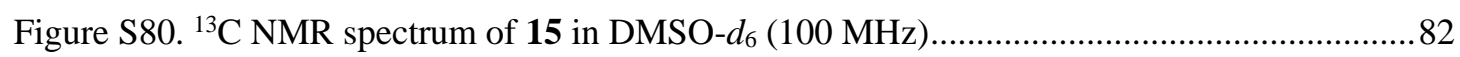

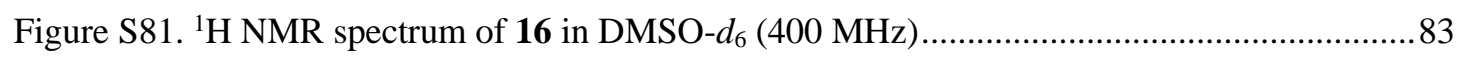

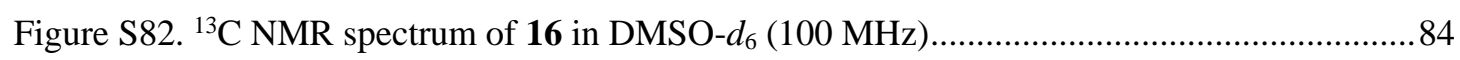

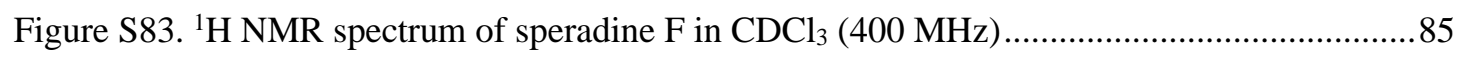

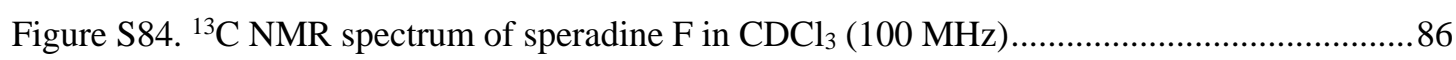

Figure S85. ${ }^{1} \mathrm{H}$ NMR spectrum of 2-(1H-indole-3-ylmethyl)-1H-3-indole-acetic acid methyl ester in $\mathrm{DMSO}^{-} d_{6}(400 \mathrm{MHz})$

Figure S86. ${ }^{13} \mathrm{C}$ NMR spectrum of 2-(1H-indole-3-ylmethyl)-1H-3-indole-acetic acid methyl ester in $\mathrm{DMSO}-d_{6}(100 \mathrm{MHz})$ 
Figure S87. ${ }^{1} \mathrm{H}$ NMR spectrum of cyclo-(L-tryptophyl-L-phenylalanyl) in DMSO- $d_{6}$ (400 MHz89

Figure S88. ${ }^{13} \mathrm{C}$ NMR spectrum of cyclo-(L-tryptophyl-L-phenylalanyl) in DMSO- $d_{6}(100 \mathrm{MHz})$

.90

Figure S89. ${ }^{1} \mathrm{H}$ NMR spectrum of 5-(1H-indol-3-ylmethyl)imidazolidine-2,4-dione in DMSO-d $d_{6}$ (400 MHz) .91

Figure S90. ${ }^{13} \mathrm{C}$ NMR spectrum of 5-(1H-indol-3-ylmethyl)imidazolidine-2,4-dione in DMSO- $d_{6}$ (100 MHz) .92

Figure S91. ${ }^{1} \mathrm{H}$ NMR spectrum of 1 -acetyl- $\beta$-carboline in $\mathrm{CDCl}_{3}(400 \mathrm{MHz}) \ldots \ldots \ldots \ldots \ldots \ldots \ldots \ldots \ldots . . . .93$

Figure S92. ${ }^{13} \mathrm{C}$ NMR spectrum of 1-acetyl- $\beta$-carboline in $\mathrm{CDCl}_{3}(100 \mathrm{MHz})$..............................94

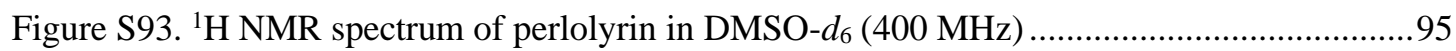

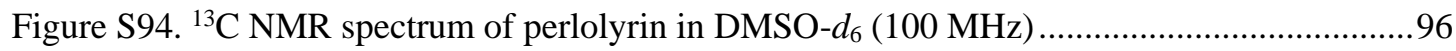

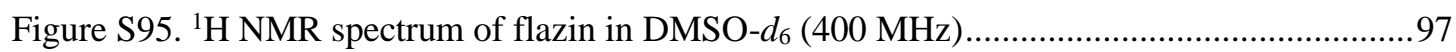

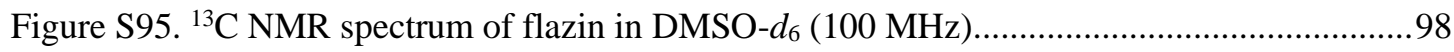

Figure S97. The optimized conformers and equilibrium populations of $2 \ldots \ldots \ldots \ldots \ldots \ldots \ldots \ldots . . . .19$

Figure S98. The optimized conformers and equilibrium populations of 5 .....................100 


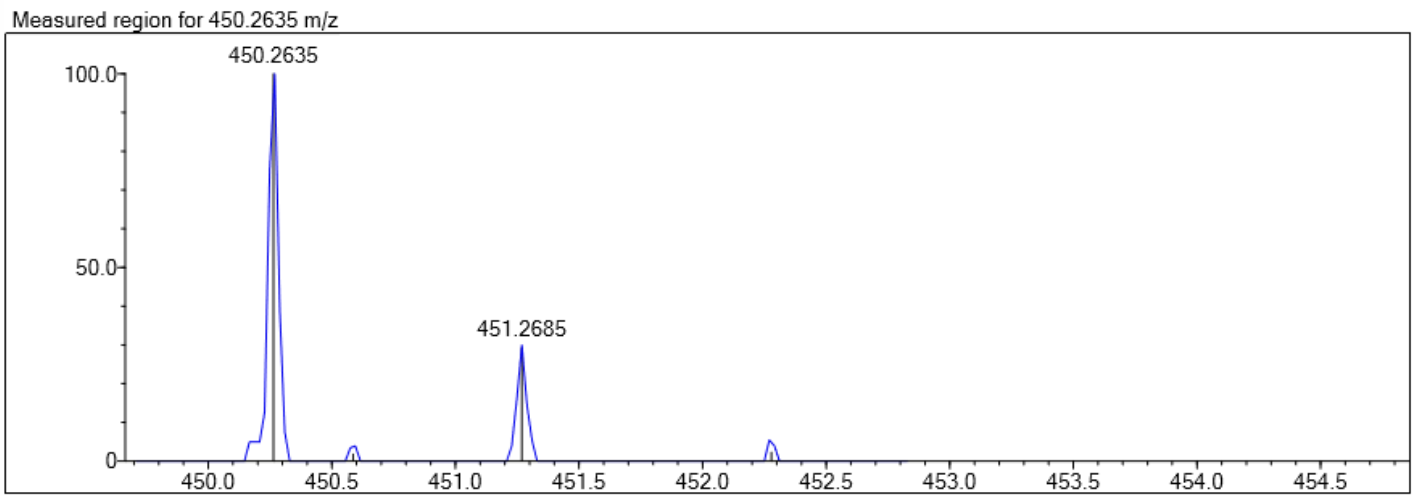

$\mathrm{C} 28 \mathrm{H} 37 \mathrm{~N} \mathrm{O} 4$ [M-H]- : Predicted region for $450.2650 \mathrm{~m} / \mathrm{z}$

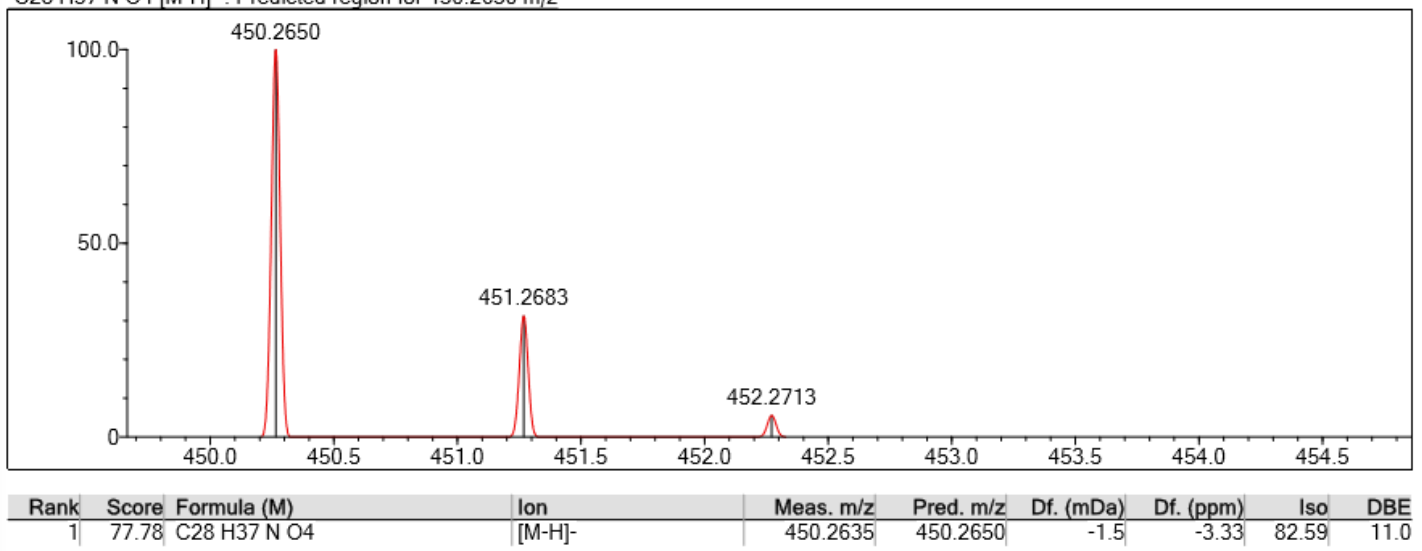

Figure S1. HR-ESIMS spectrum of fusaindoterpene A (1) 
<smiles>CC(C)=C[C@H]1C[C@]2(C)[C@@H](CC[C@]3(C)[C@@H]4OC(=O)NC5C=CC=CC5C(=O)C[C@@H]4CC[C@H]23)O1</smiles>

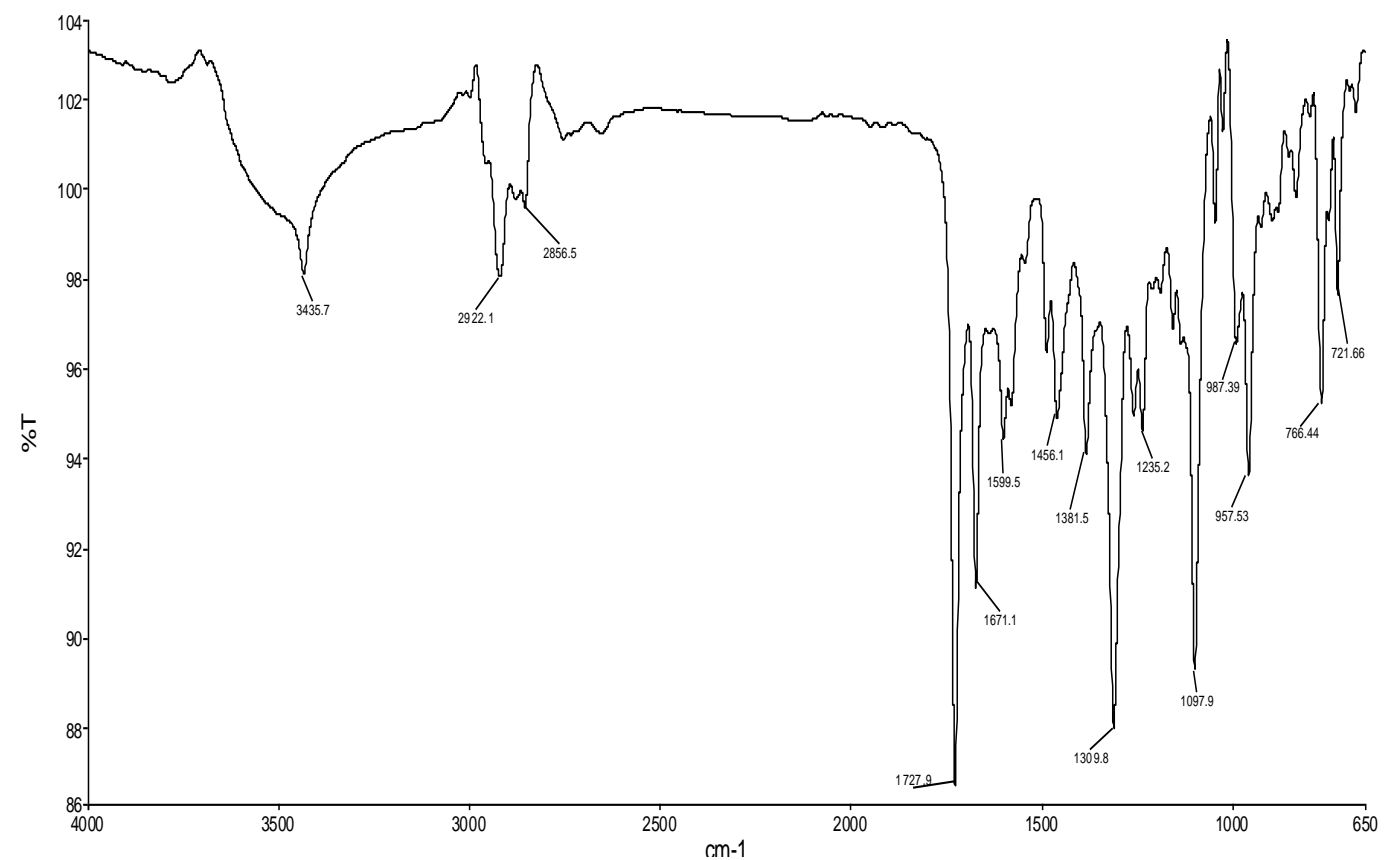

Figure S2. The IR spectrum of fusaindoterpene A (1) 
<smiles>CC(C)=C[C@H]1C[C@@]2(C)[C@H]3CC[C@H]4CC(=O)C5C=CC=CC5NC(=O)O[C@@H]4[C@@H]3CC[C@H]2O1</smiles>

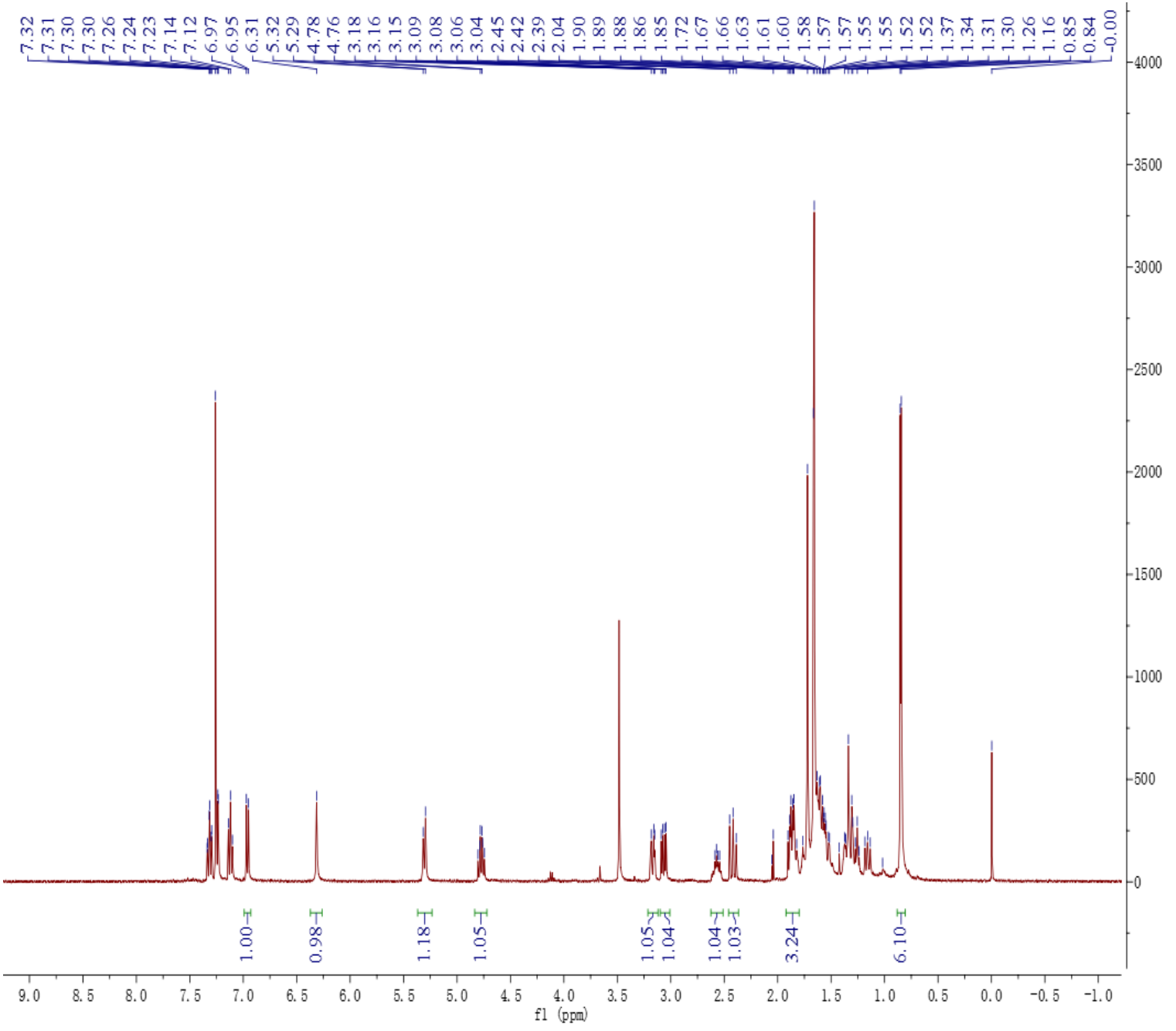

Figure S3. ${ }^{1} \mathrm{H}$ NMR spectrum of fusaindoterpene $\mathrm{A}(\mathbf{1})$ in $\mathrm{CDCl}_{3}(400 \mathrm{MHz})$ 


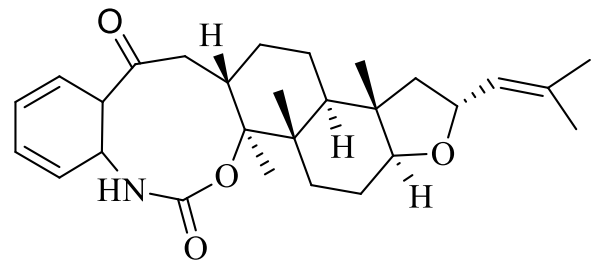

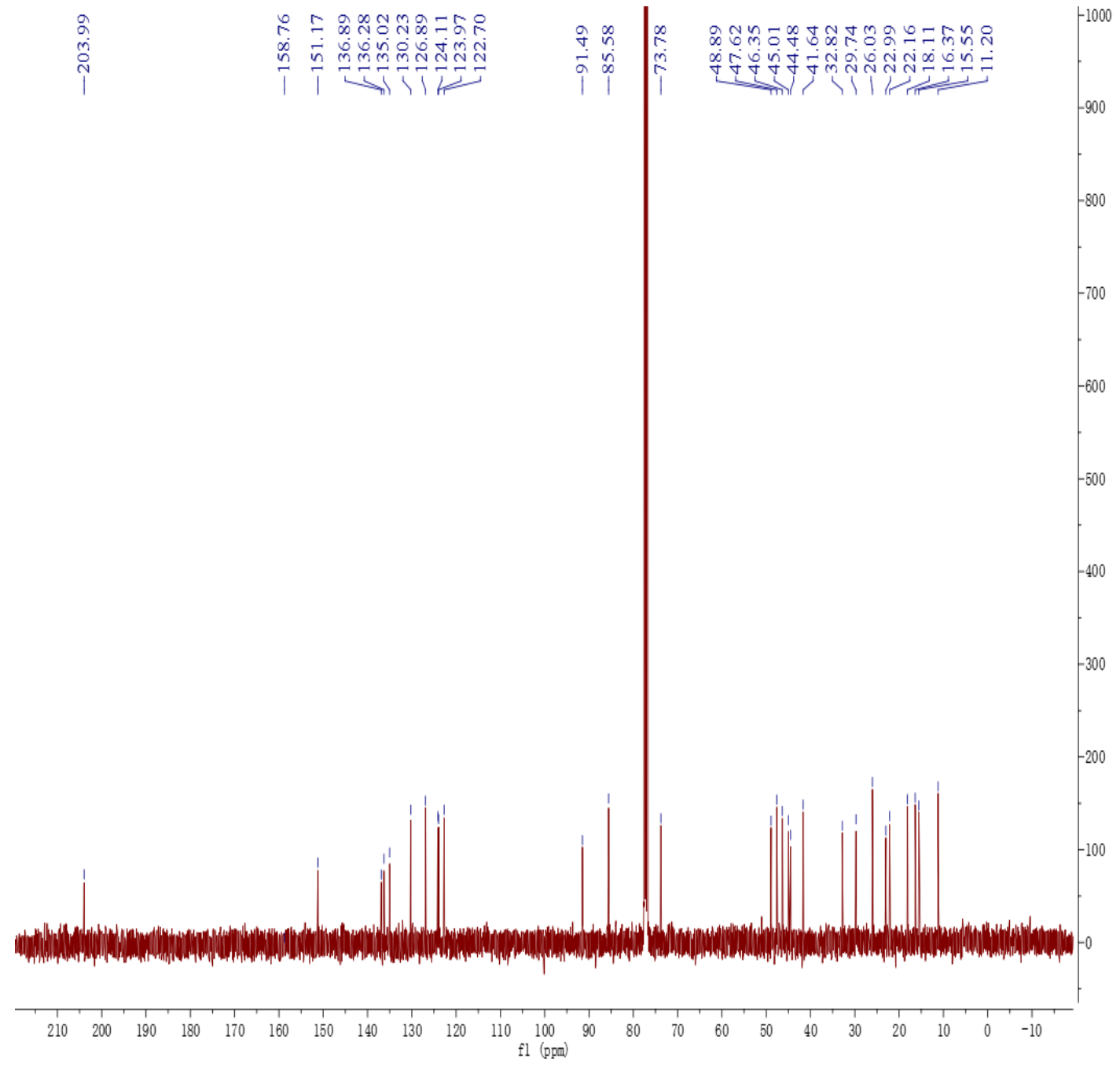

Figure S4. ${ }^{13} \mathrm{C}$ NMR spectrum of fusaindoterpene $\mathrm{A}(\mathbf{1})$ in $\mathrm{CDCl}_{3}(100 \mathrm{MHz})$ 
<smiles>CC(C)=C[C@H]1C[C@]2(C)[C@@H](CC[C@]3(C)[C@H]4OC(=O)NC5C=CC=CC5C(=O)C[C@@H]4CC[C@@H]32)O1</smiles>

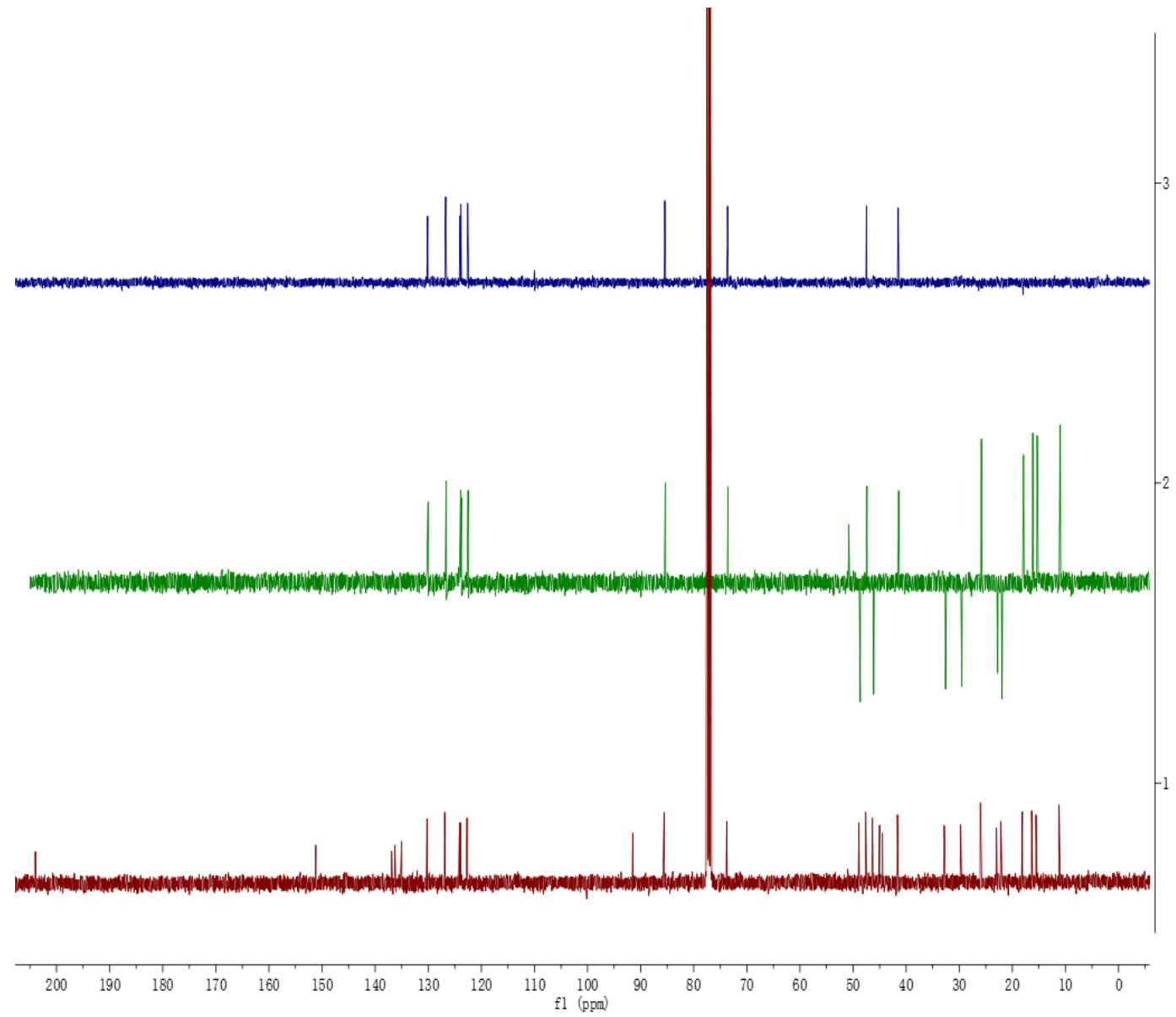

Figure S5. DEPT 90 and DEPT 135 spectra of fusaindoterpene A (1) in $\mathrm{CDCl}_{3}$ 


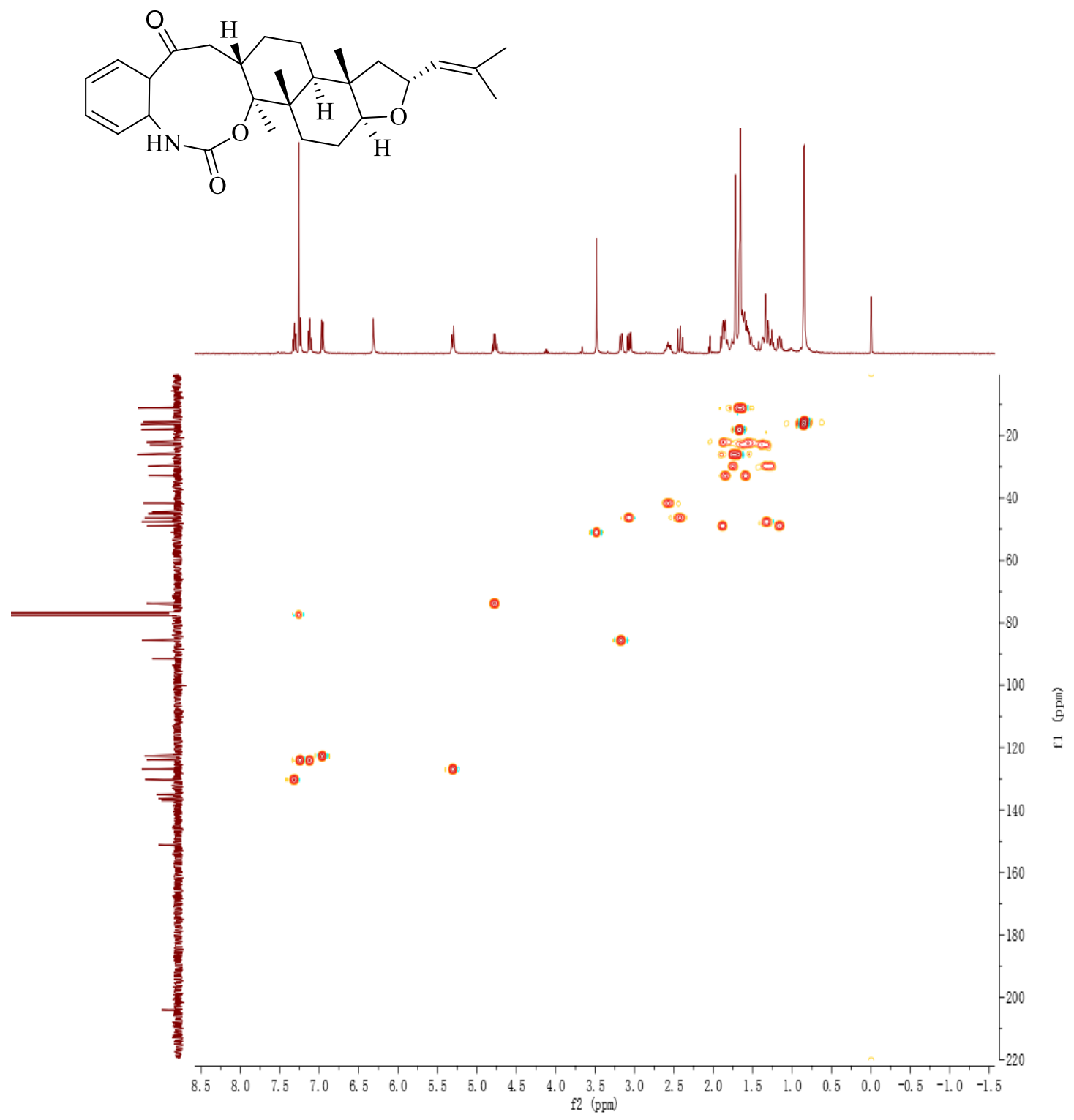

Figure S6. HMQC spectrum of fusaindoterpene $\mathrm{A}(\mathbf{1})$ in $\mathrm{CDCl}_{3}$ 

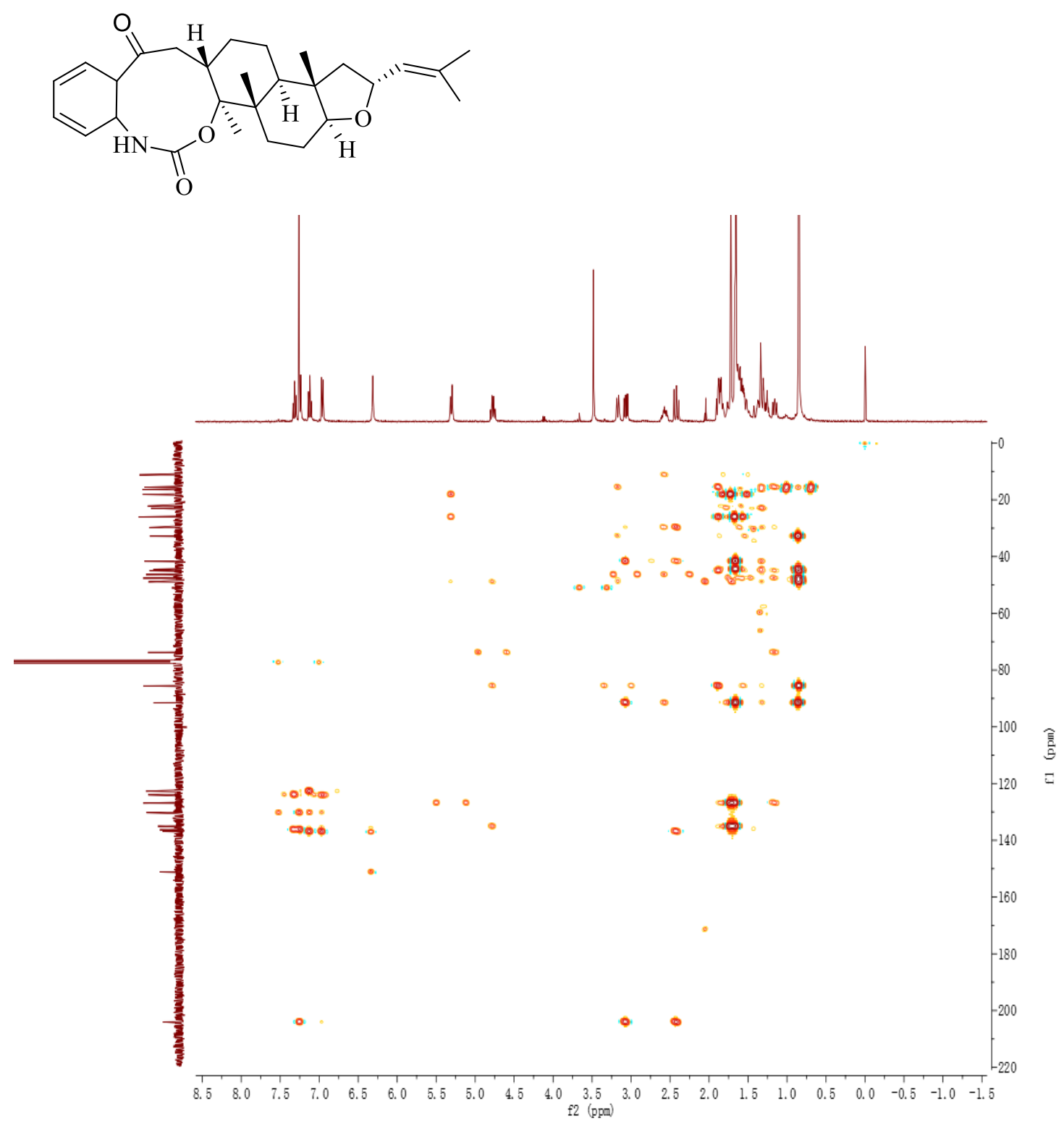

Figure S7. HMBC spectrum of fusaindoterpene $\mathrm{A}(\mathbf{1})$ in $\mathrm{CDCl}_{3}$ 

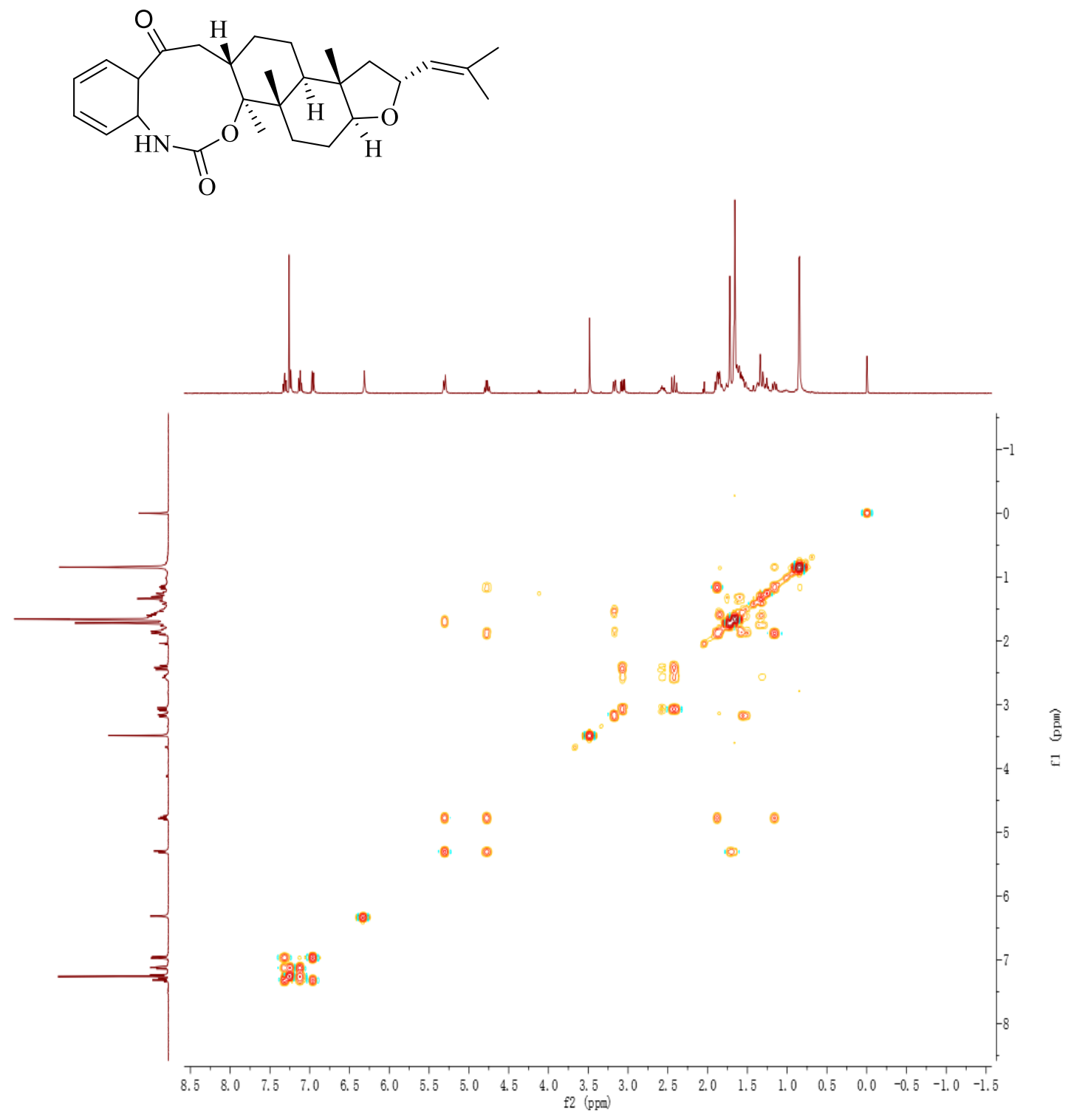

Figure S8. COSY spectrum of fusaindoterpene $\mathrm{A}(\mathbf{1})$ in $\mathrm{CDCl}_{3}$ 


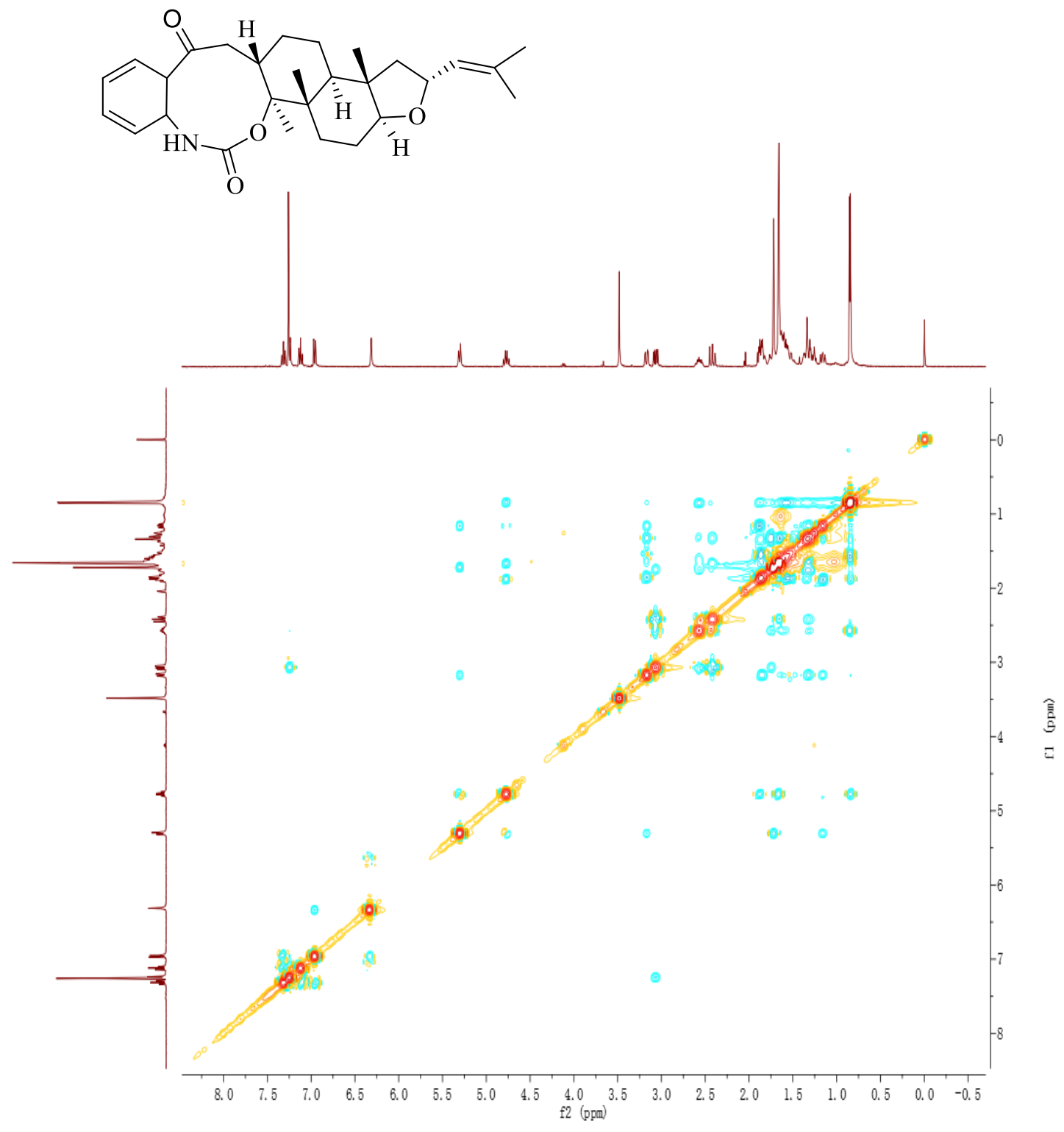

Figure S9. NOESY spectrum of fusaindoterpene $\mathrm{A}(\mathbf{1})$ in $\mathrm{CDCl}_{3}$ 


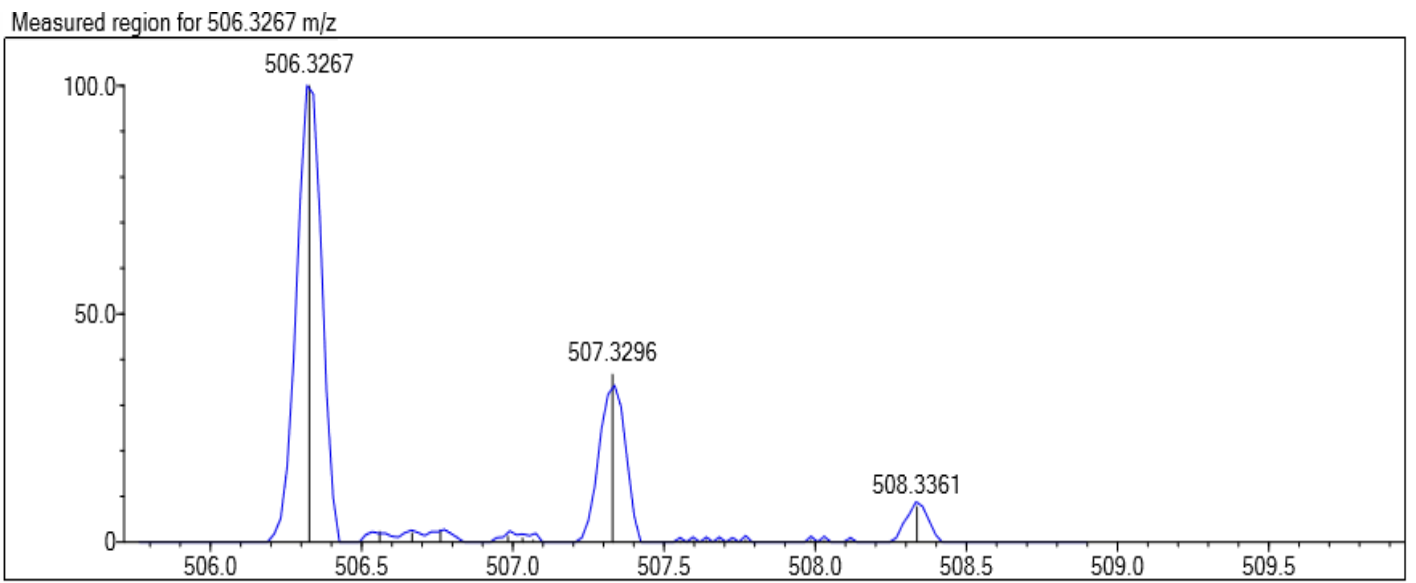

C32 $\mathrm{H} 43 \mathrm{~N} 04[\mathrm{M}+\mathrm{H}]+$ : Predicted region for $506.3265 \mathrm{~m} / \mathrm{z}$

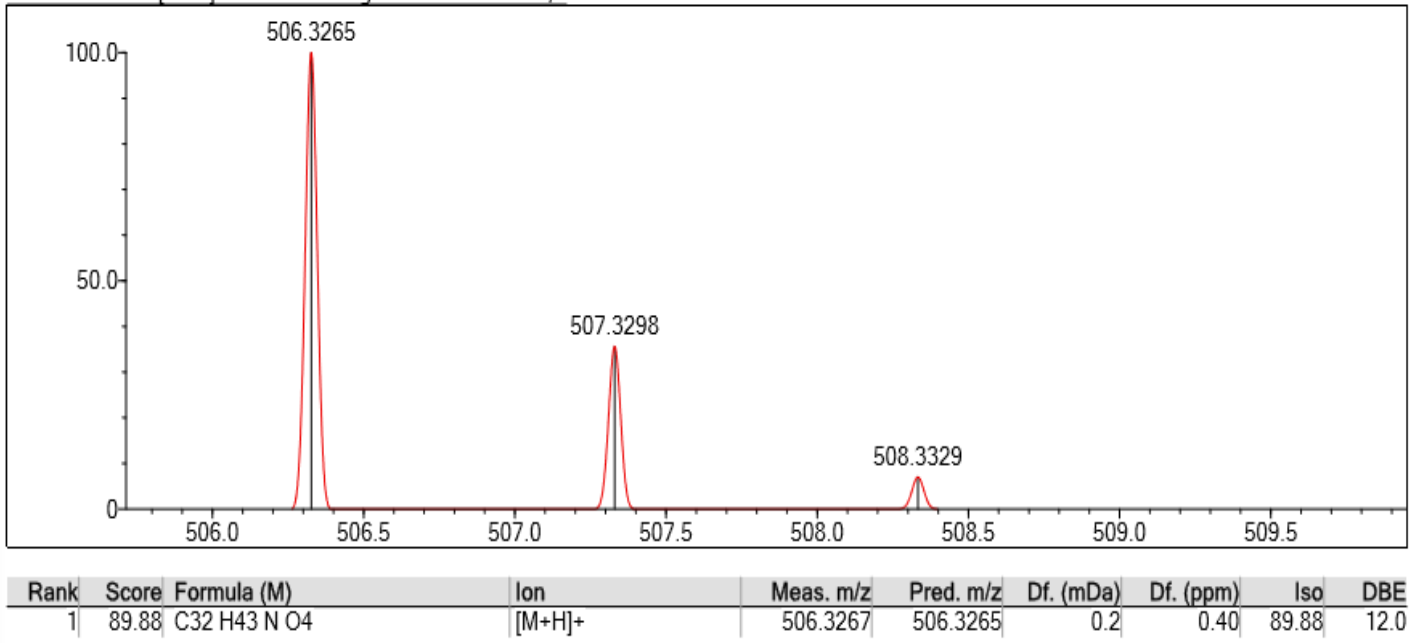

Figure S10. HR-ESIMS spectrum of fusaindoterpene B (2) 

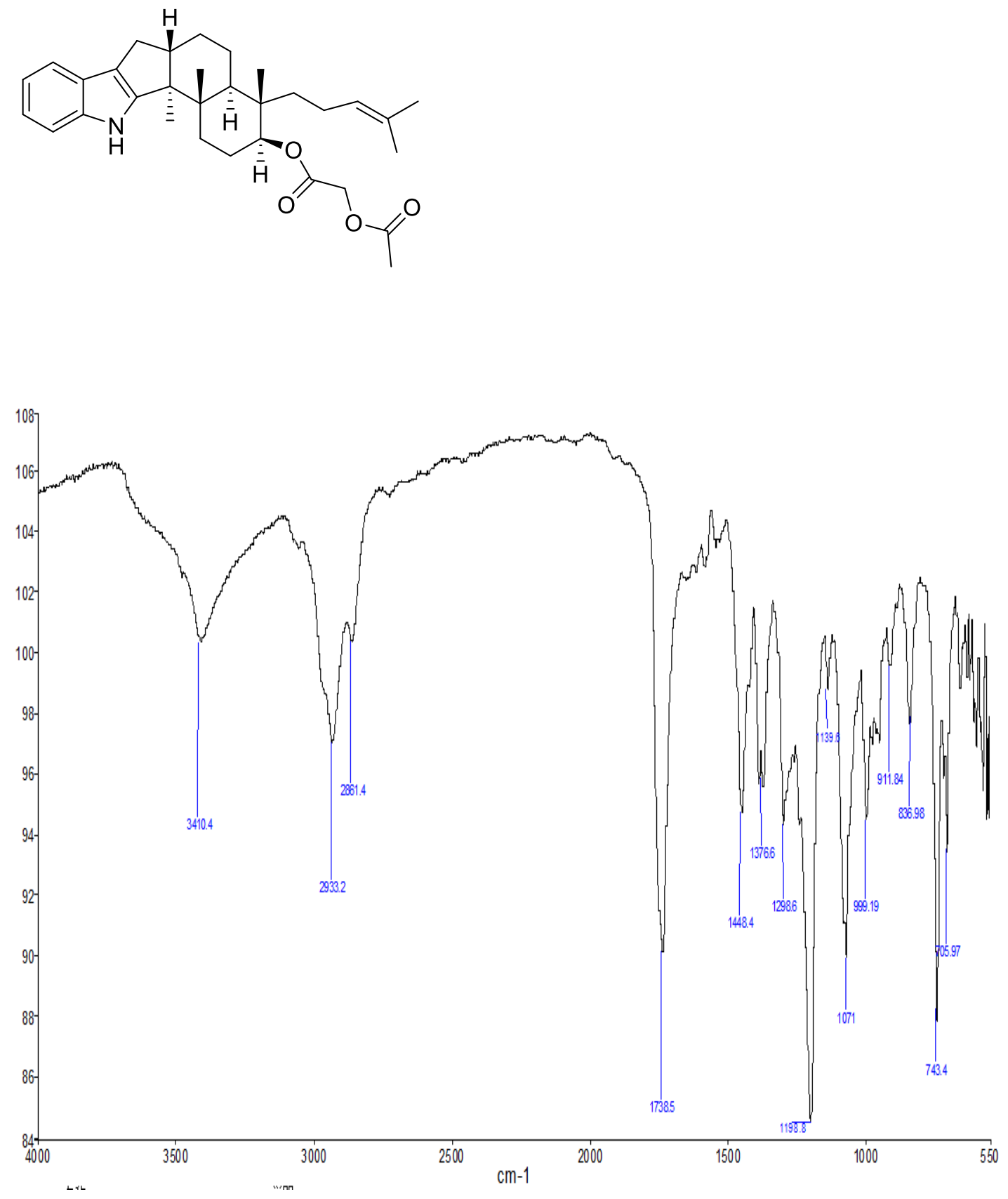

Figure S11. The IR spectrum of fusaindoterpene B (2) 
<smiles>CC(=O)OCC(=O)O[C@H]1CC[C@]2(C)[C@@H]3c4[nH]c5ccccc5c4C[C@H]3CC[C@]2(C)[C@@H]1CCC=C(C)C</smiles>

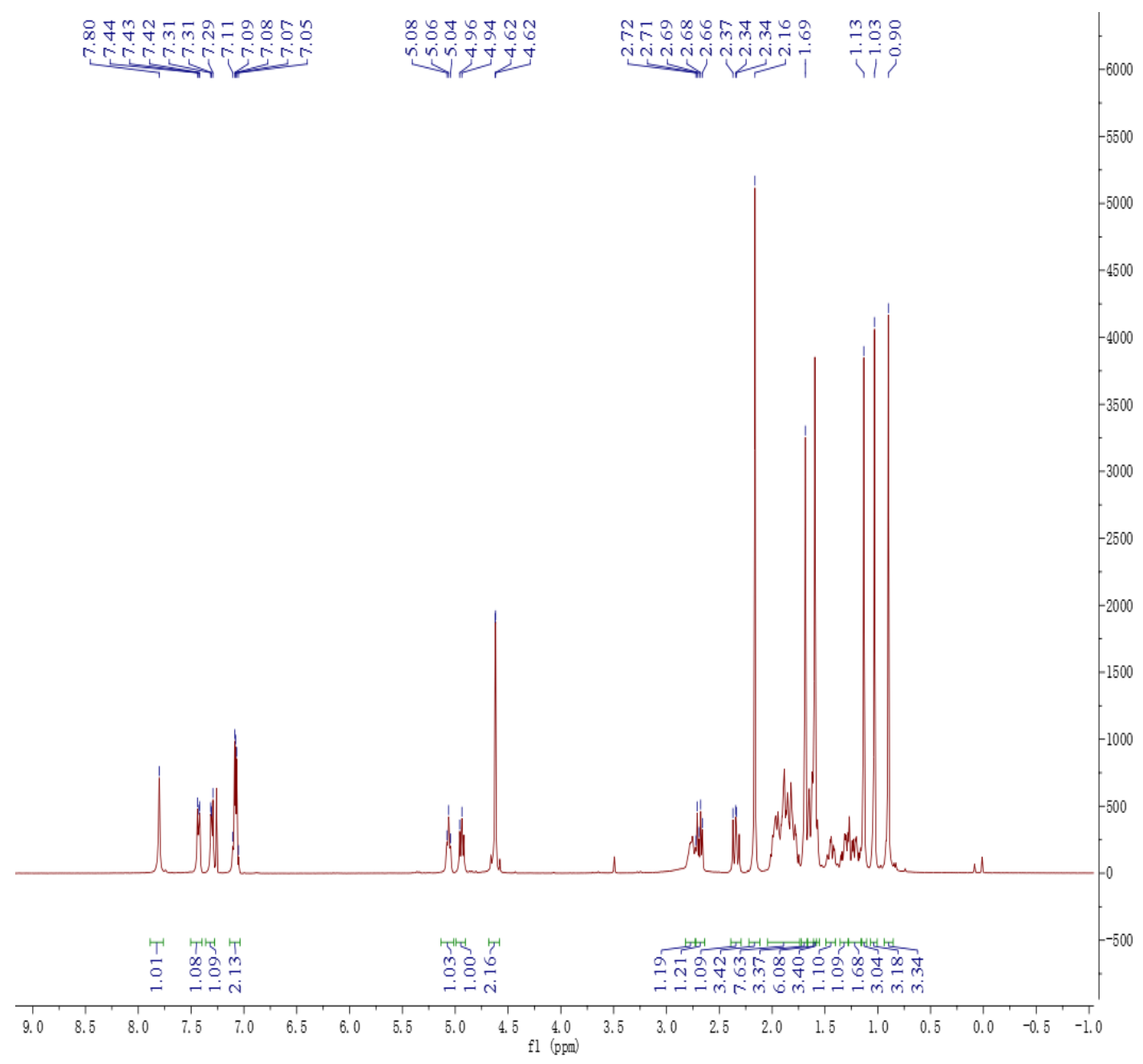

Figure S12. ${ }^{1} \mathrm{H}$ NMR spectrum of fusaindoterpene B (2) in $\mathrm{CDCl}_{3}(400 \mathrm{MHz})$ 

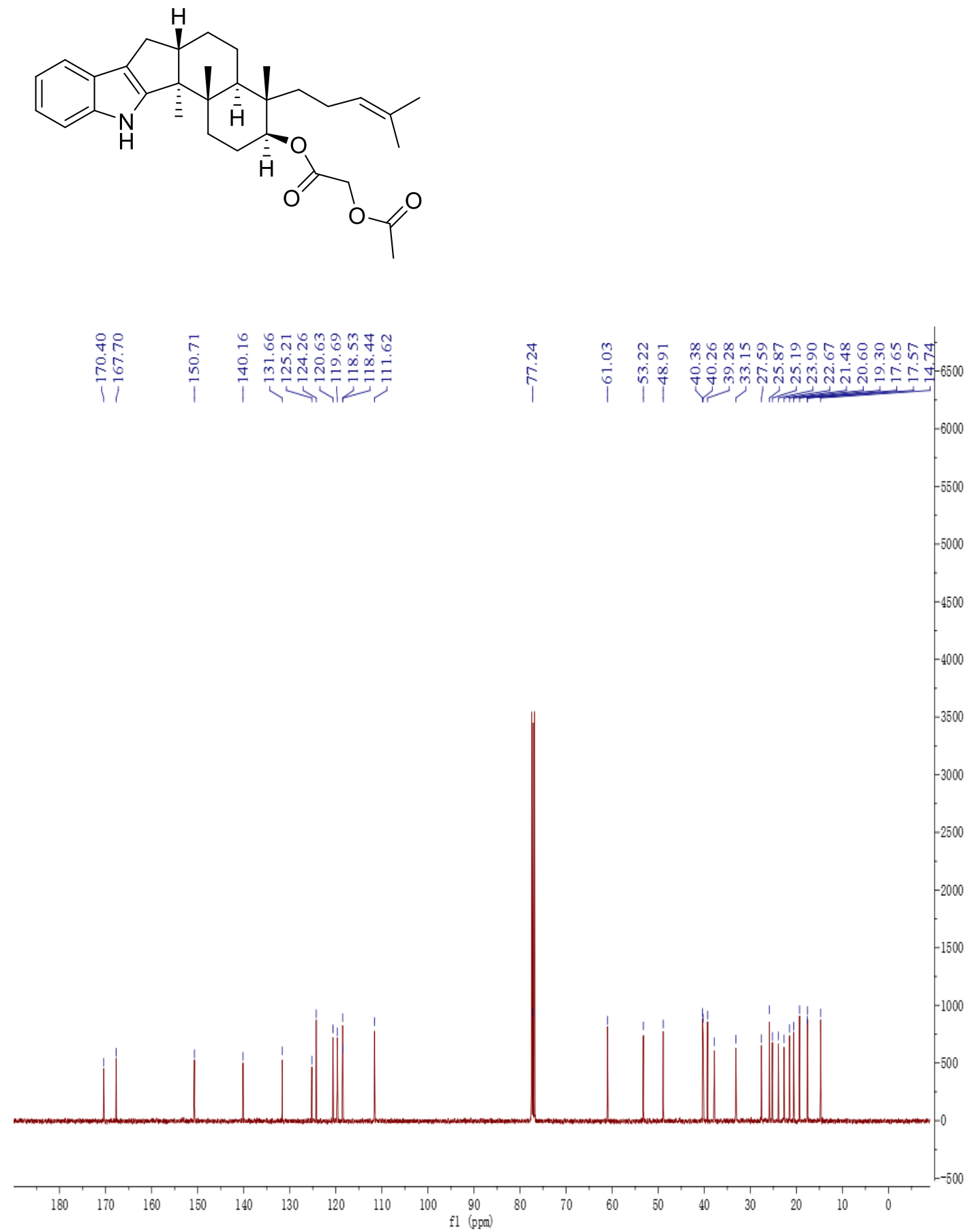

Figure $\mathrm{S} 13 .{ }^{13} \mathrm{C}$ NMR spectrum of fusaindoterpene $\mathrm{B}(2)$ in $\mathrm{CDCl}_{3}(100 \mathrm{MHz})$ 

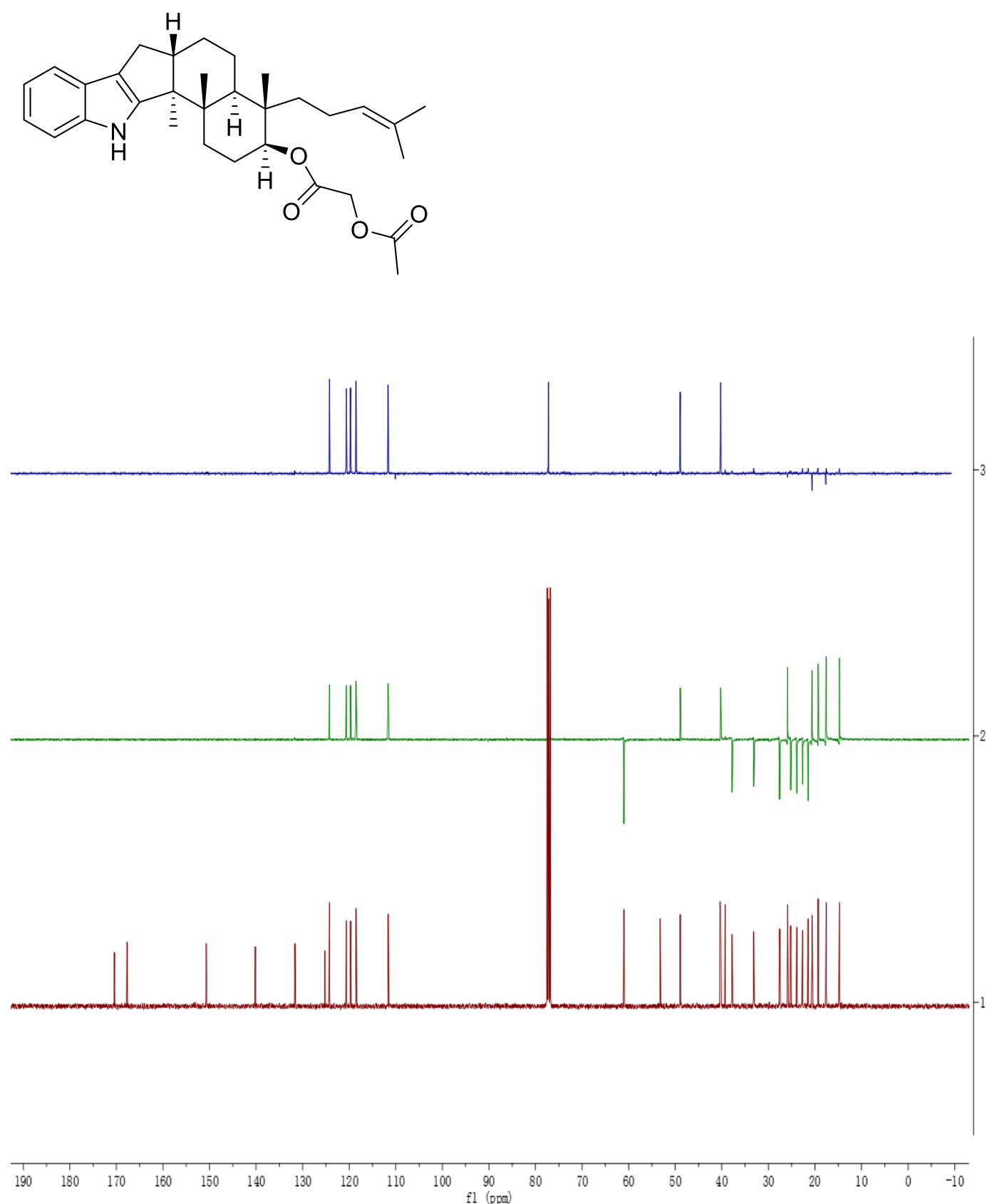

Figure S14. DEPT 90 and DEPT 135 spectra of fusaindoterpene B (2) in $\mathrm{CDCl}_{3}$ 

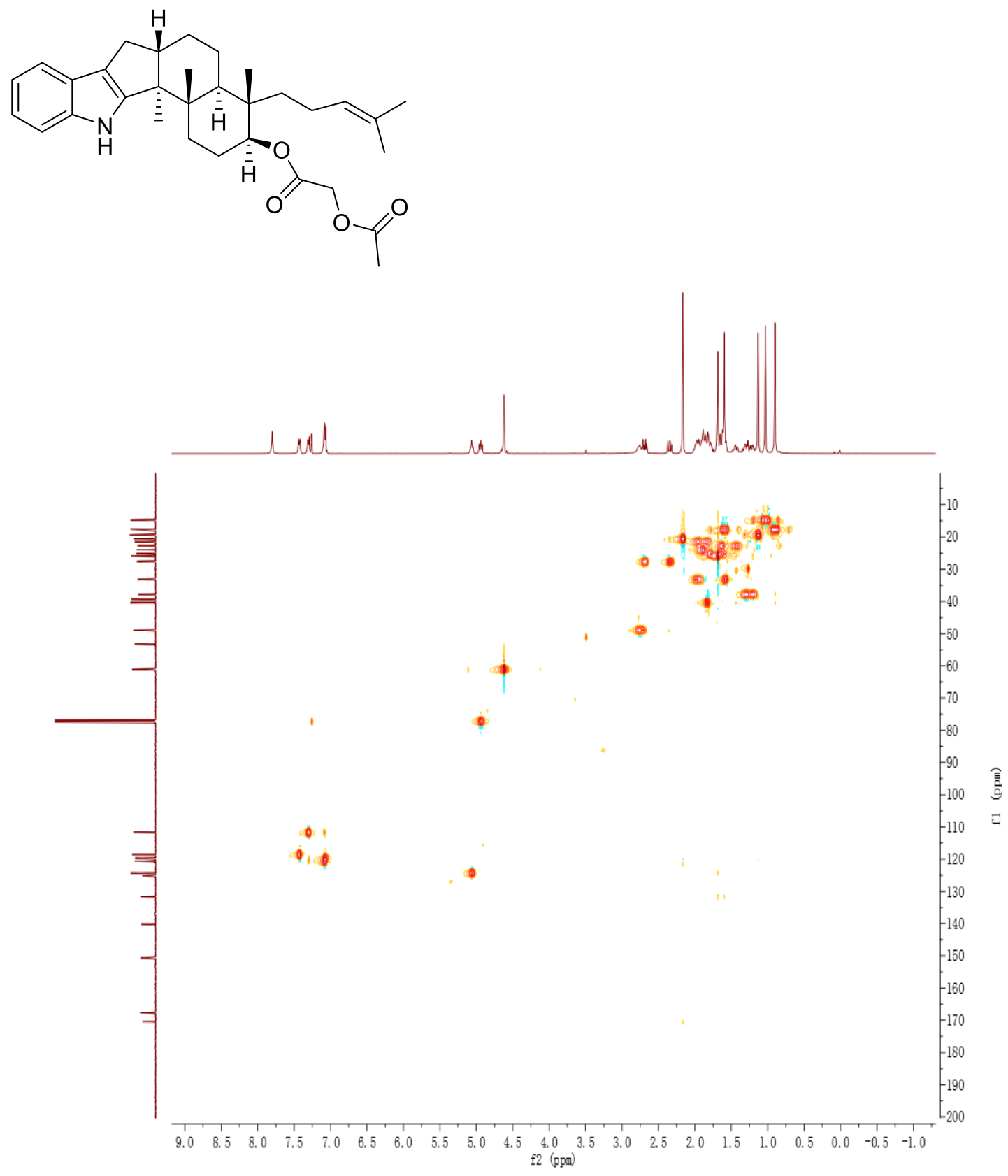

Figure S15. HMQC spectrum of fusaindoterpene B (2) in $\mathrm{CDCl}_{3}$ 

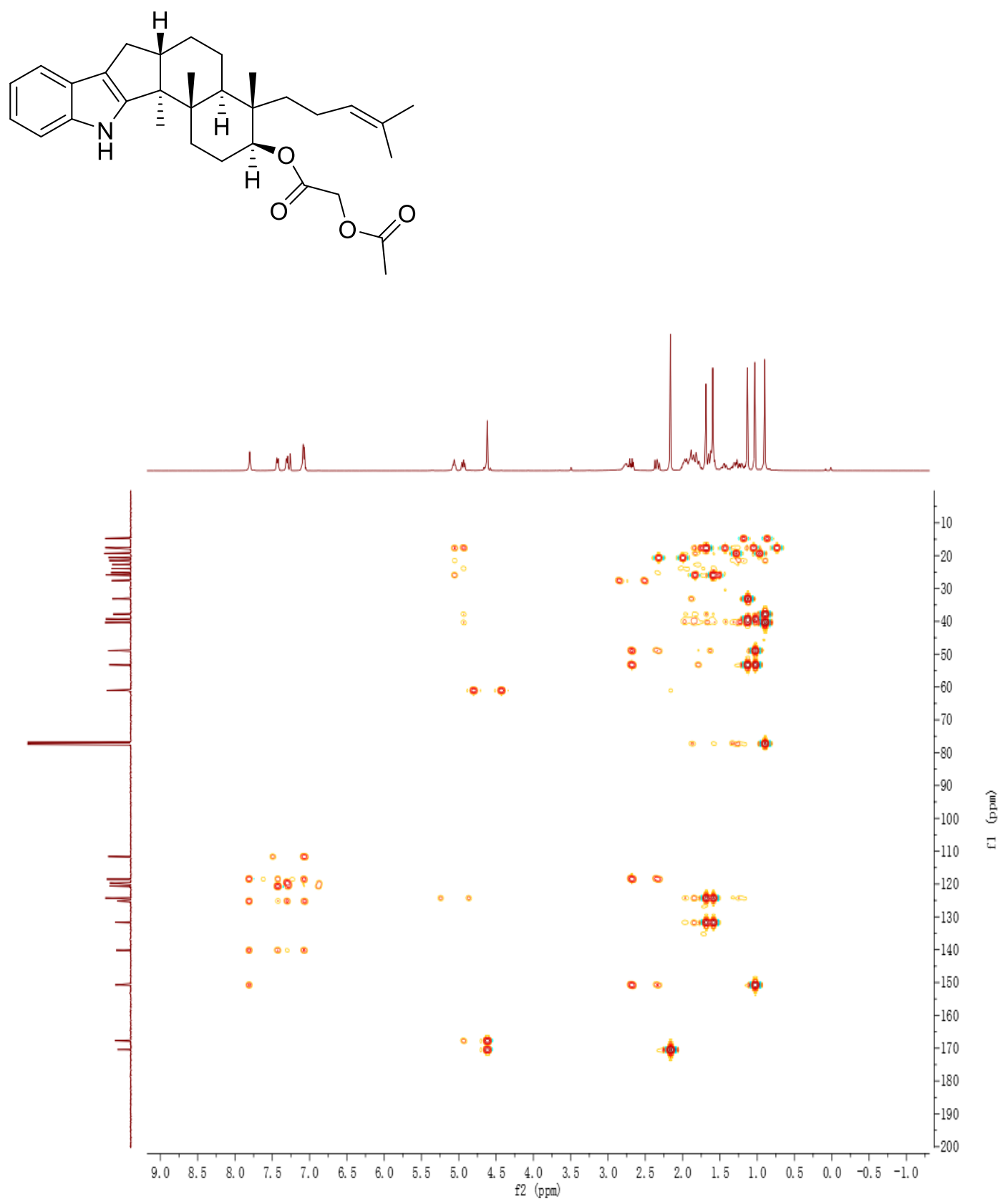

Figure S16. $\mathrm{HMBC}$ spectrum of fusaindoterpene $\mathrm{B}(2)$ in $\mathrm{CDCl}_{3}$ 

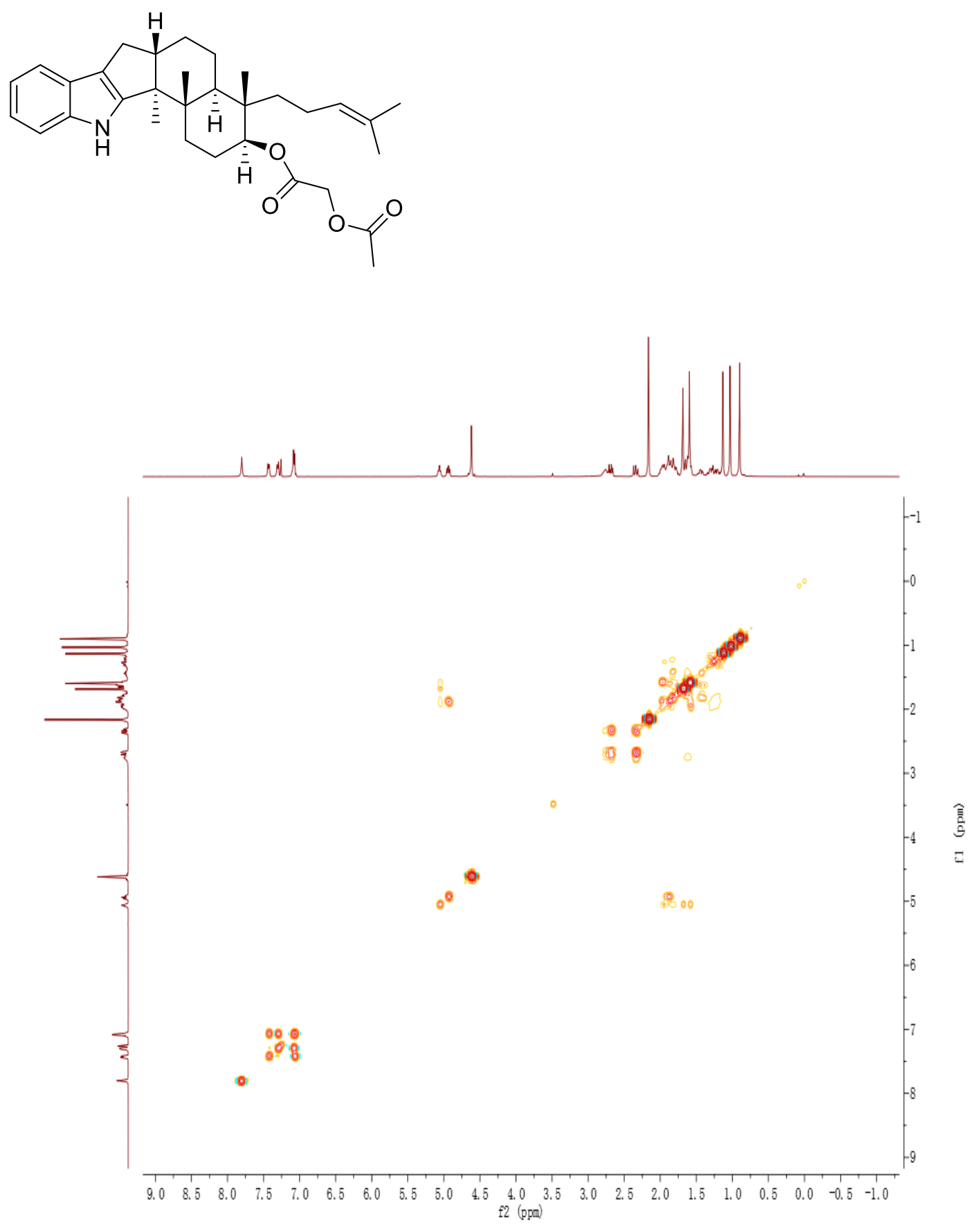

Figure S17. COSY spectrum of fusaindoterpene B (2) in $\mathrm{CDCl}_{3}$ 

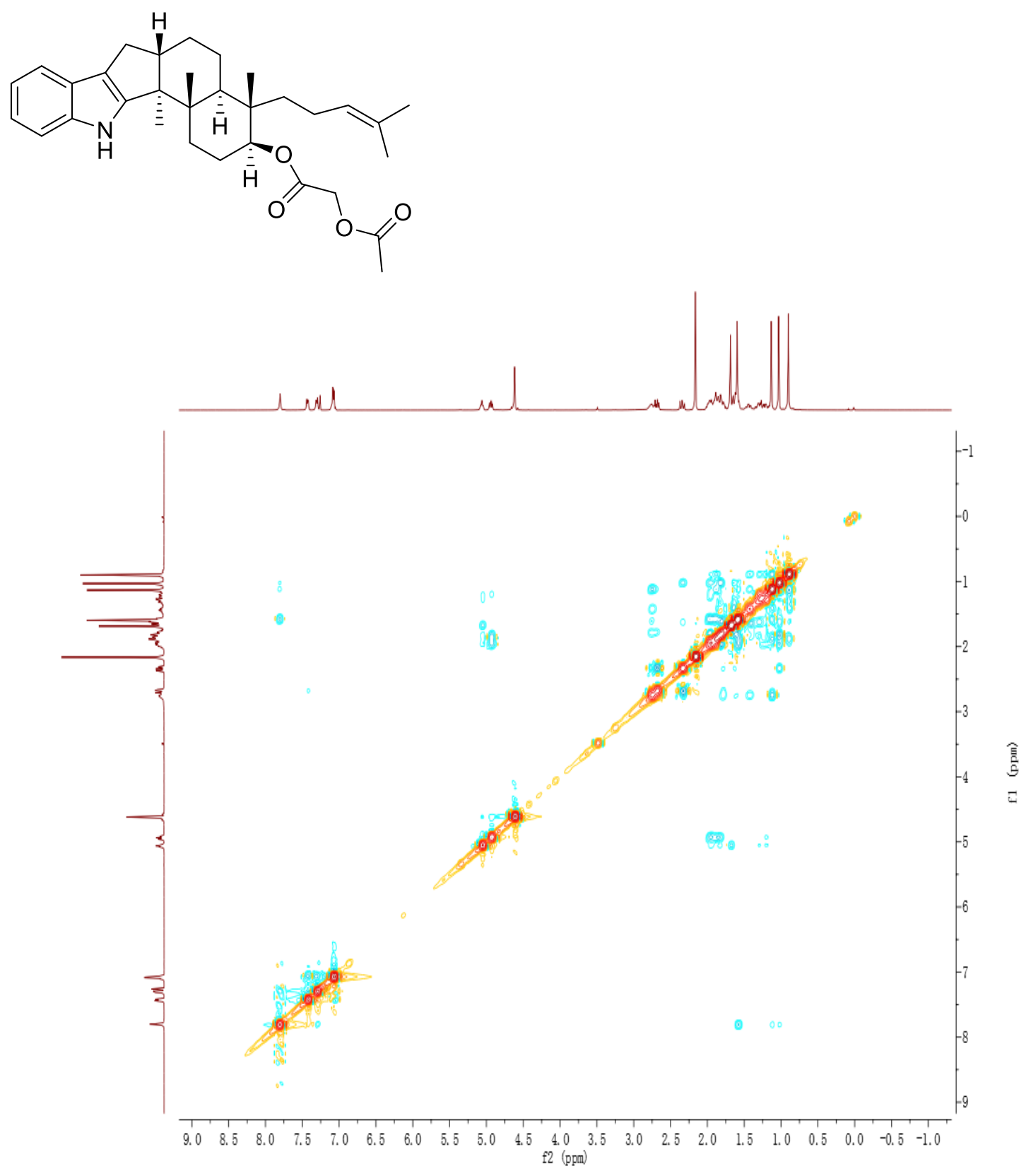

Figure S18. NOESY spectrum of fusaindoterpene B (2) in $\mathrm{CDCl}_{3}$ 


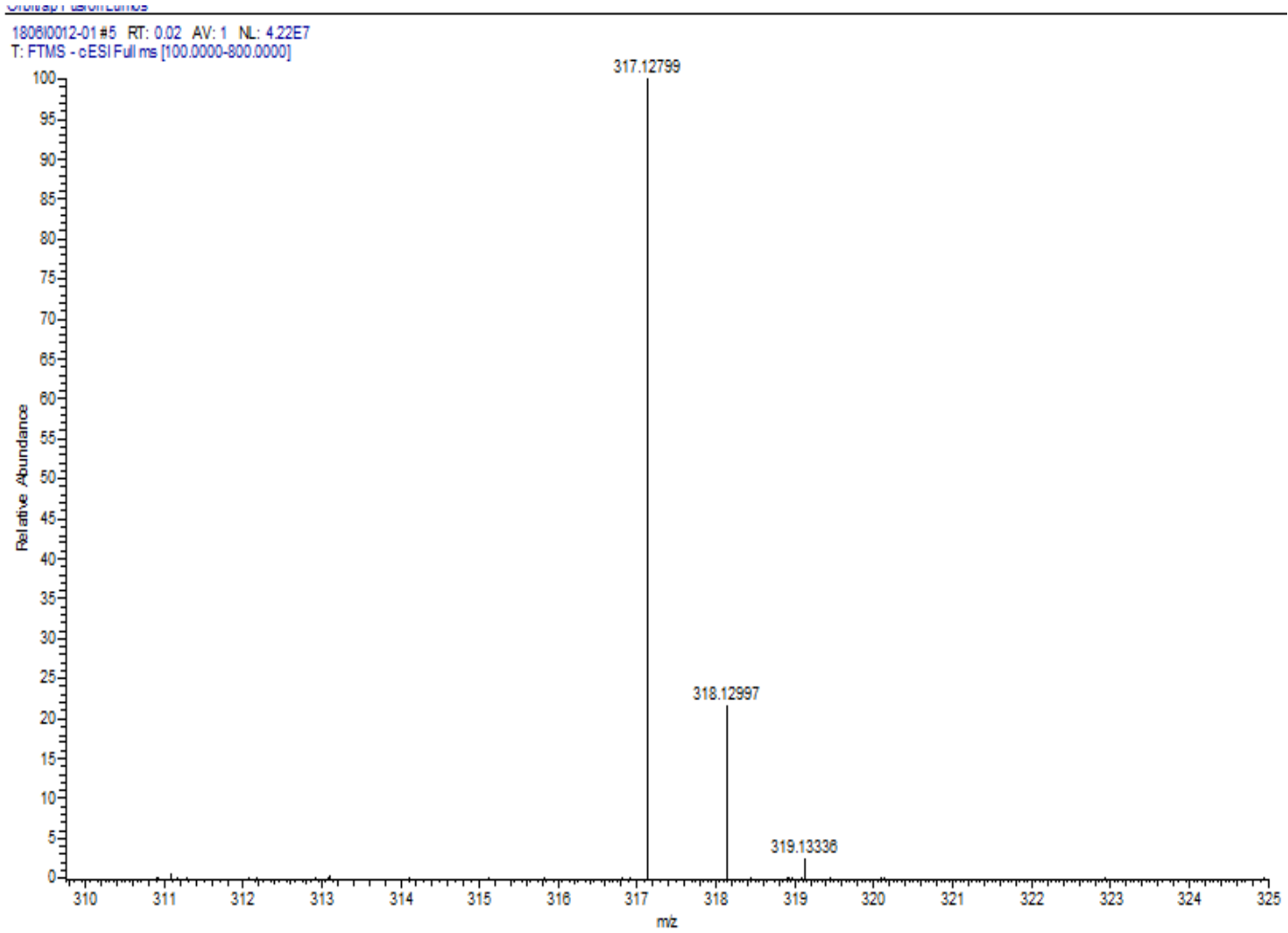

Figure S19. HR-ESIMS spectrum of fusariumindole A (3) 
<smiles>O=C(Cc1c[nH]c2ccccc12)OCCc1c[nH]c2ccccc12</smiles>

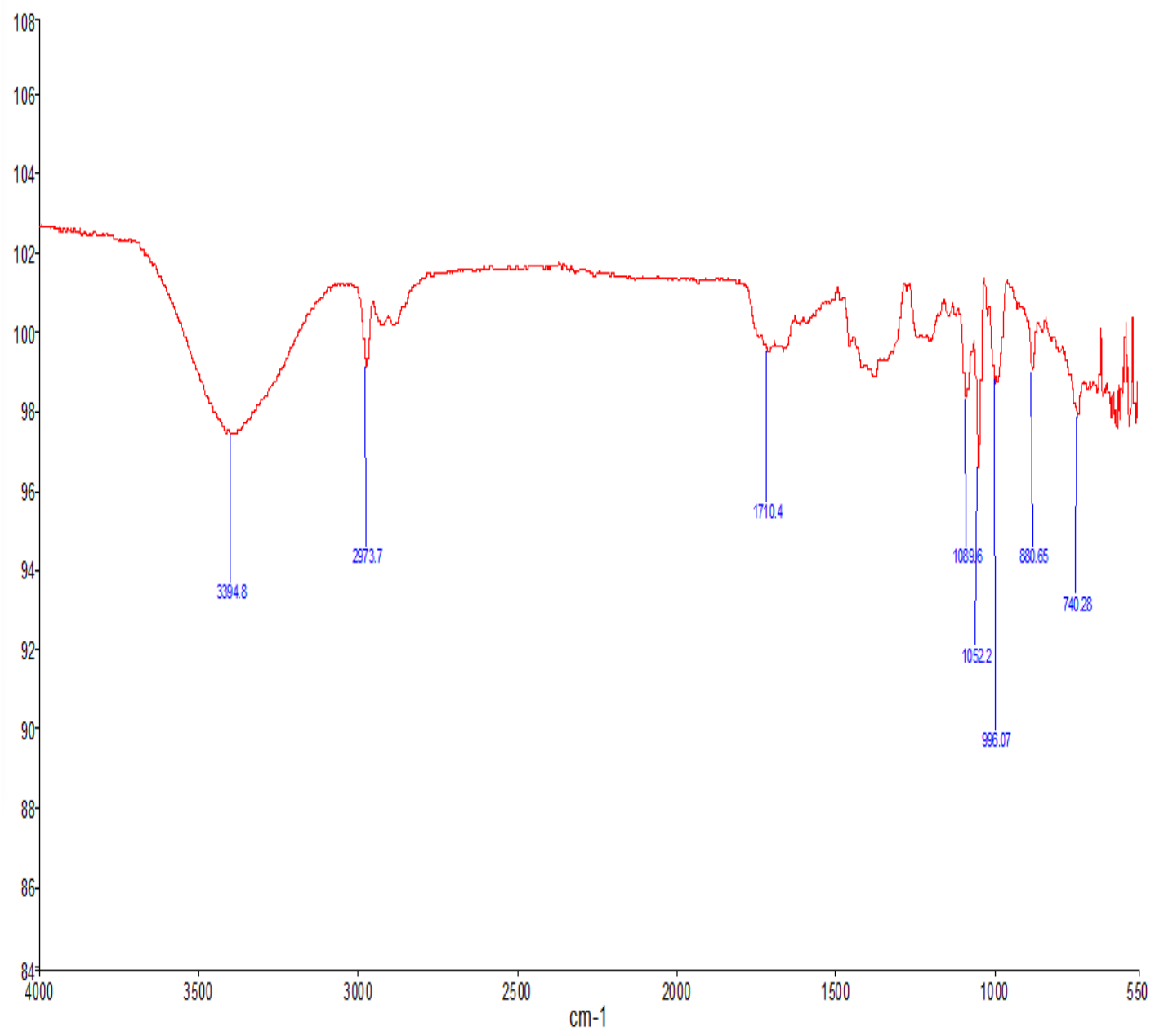

Figure S20. The IR spectrum of fusariumindole A (3) 
<smiles>O=C(Cc1c[nH]c2ccccc12)OCCc1c[nH]c2ccccc12</smiles>

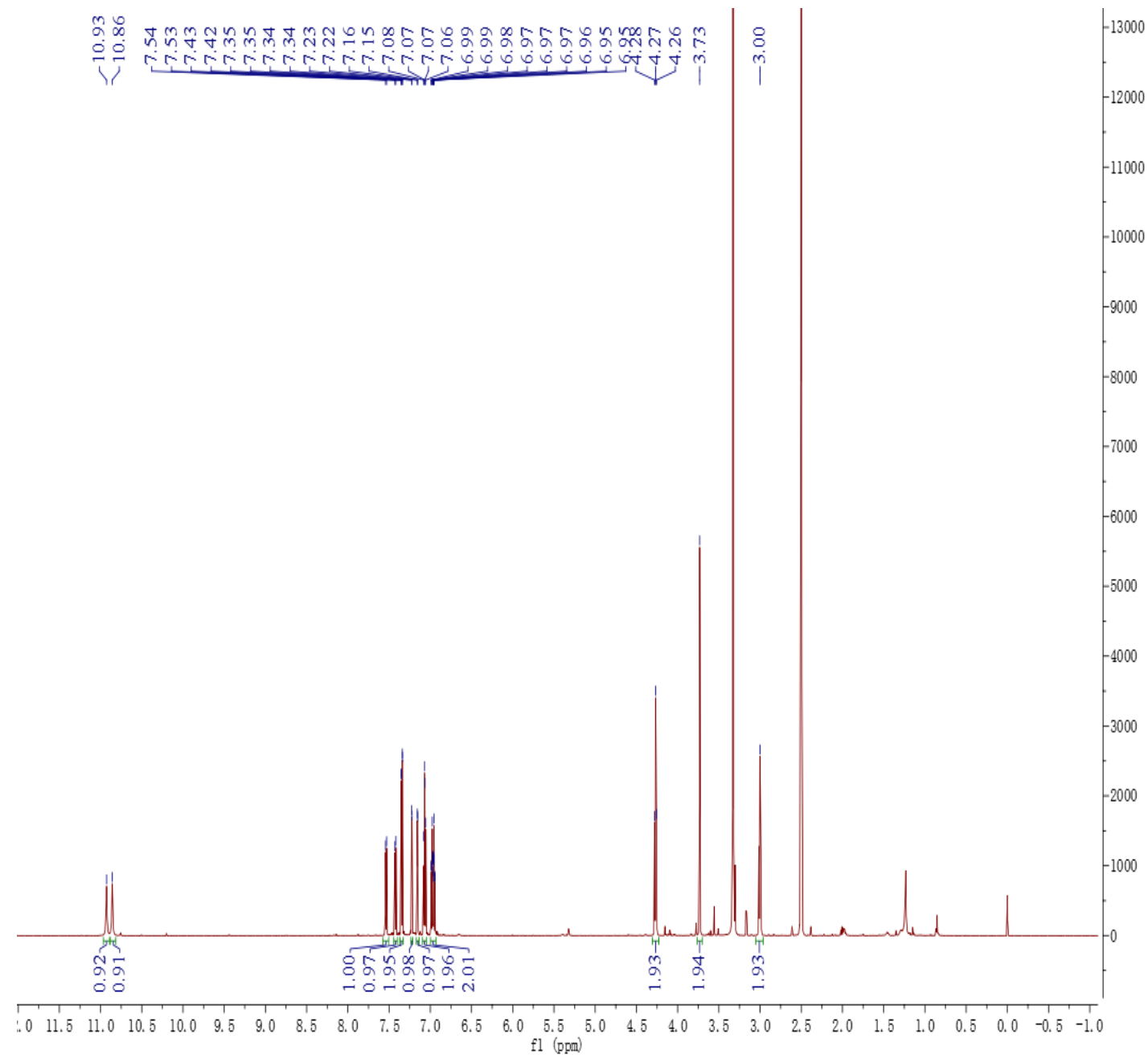

Figure S21. ${ }^{1} \mathrm{H}$ NMR spectrum of fusariumindole A (3) in DMSO- $d_{6}(600 \mathrm{MHz})$ 
<smiles>O=C(Cc1c[nH]c2ccccc12)OCCc1c[nH]c2ccccc12</smiles>

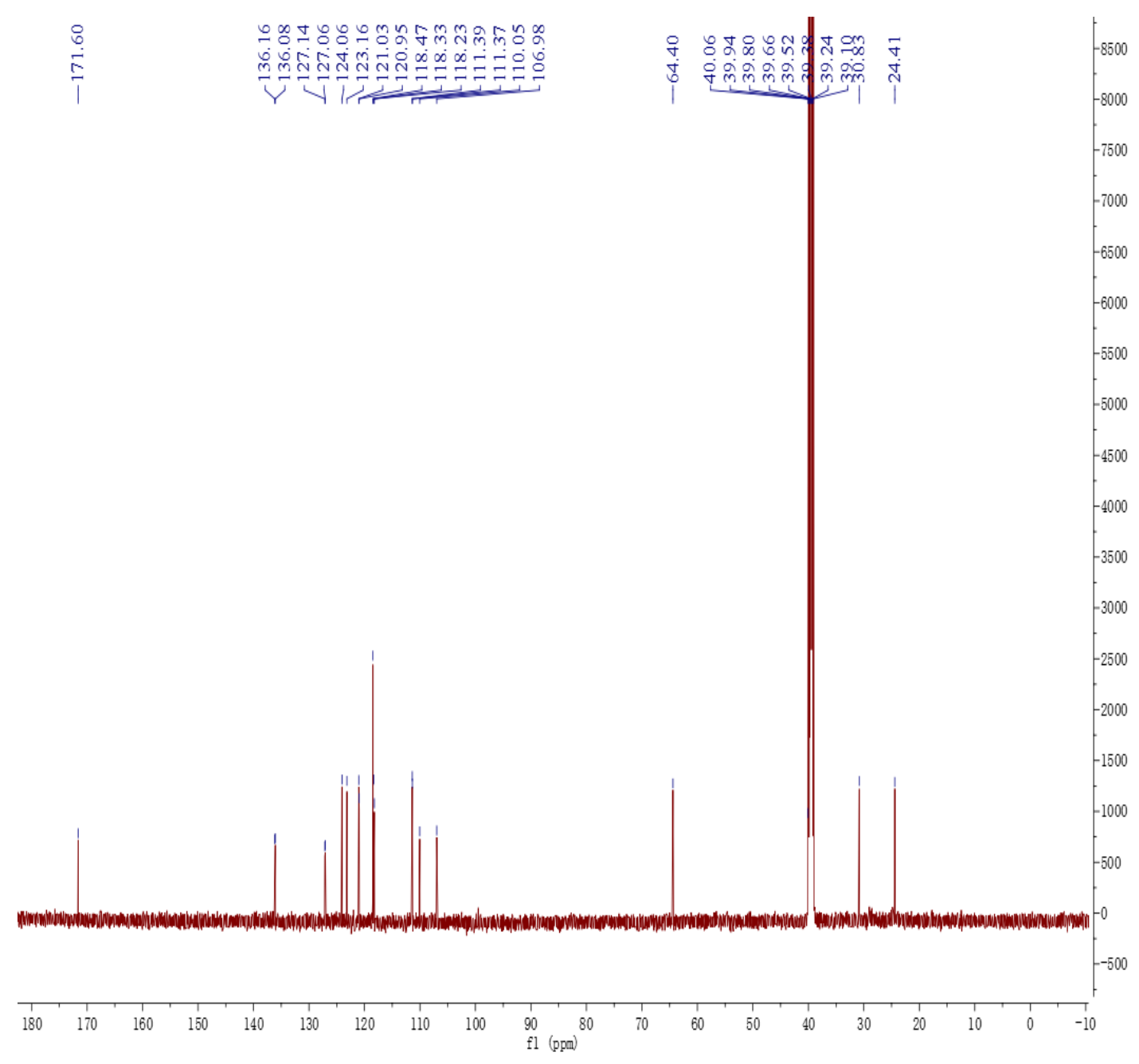

Figure S22. ${ }^{13} \mathrm{C}$ NMR spectrum of fusariumindole A (3) in DMSO- $d_{6}(150 \mathrm{MHz})$ 
<smiles>O=C(Cc1c[nH]c2ccccc12)OCCc1c[nH]c2ccccc12</smiles>

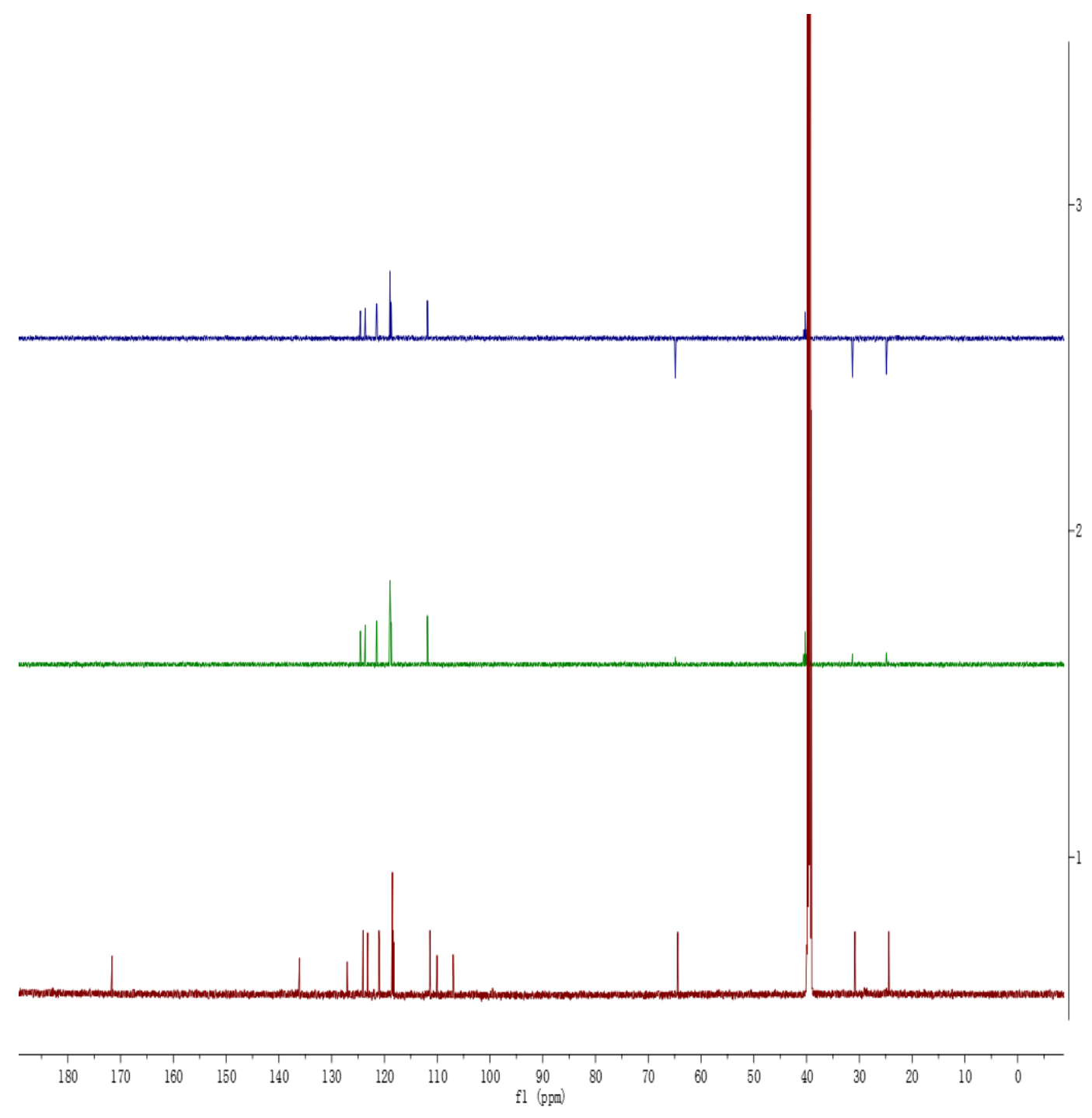

Figure S23. DEPT 90 and DEPT 135 spectra of fusariumindole A (3) in DMSO- $d_{6}$ 


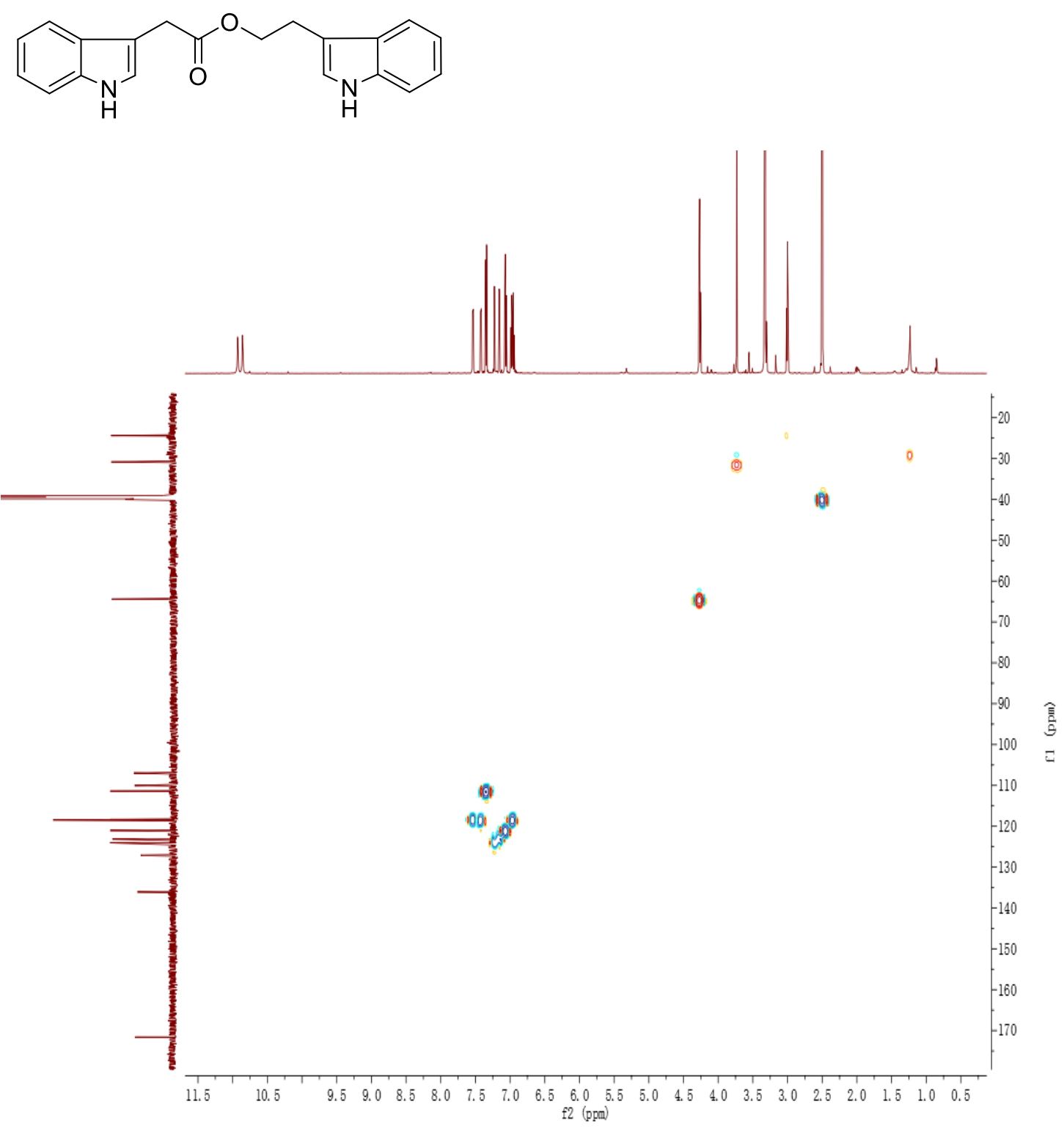

Figure S24. HMQC spectrum of fusariumindole A (3) in DMSO- $d_{6}$ 


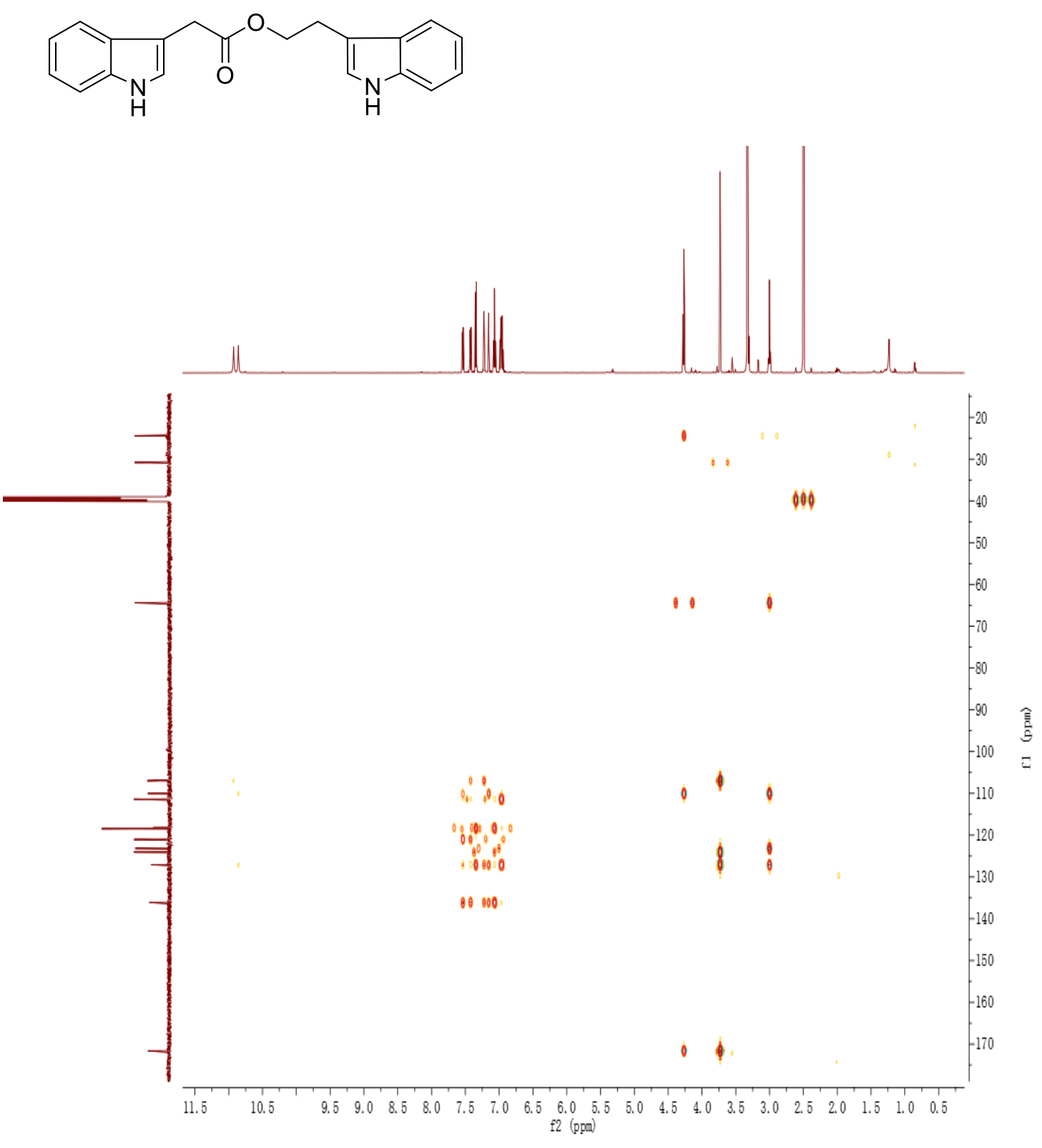

Figure S25. HMBC spectrum of fusariumindole A (3) in DMSO- $d_{6}$ 
<smiles>O=C(Cc1c[nH]c2ccccc12)OCCc1c[nH]c2ccccc12</smiles>

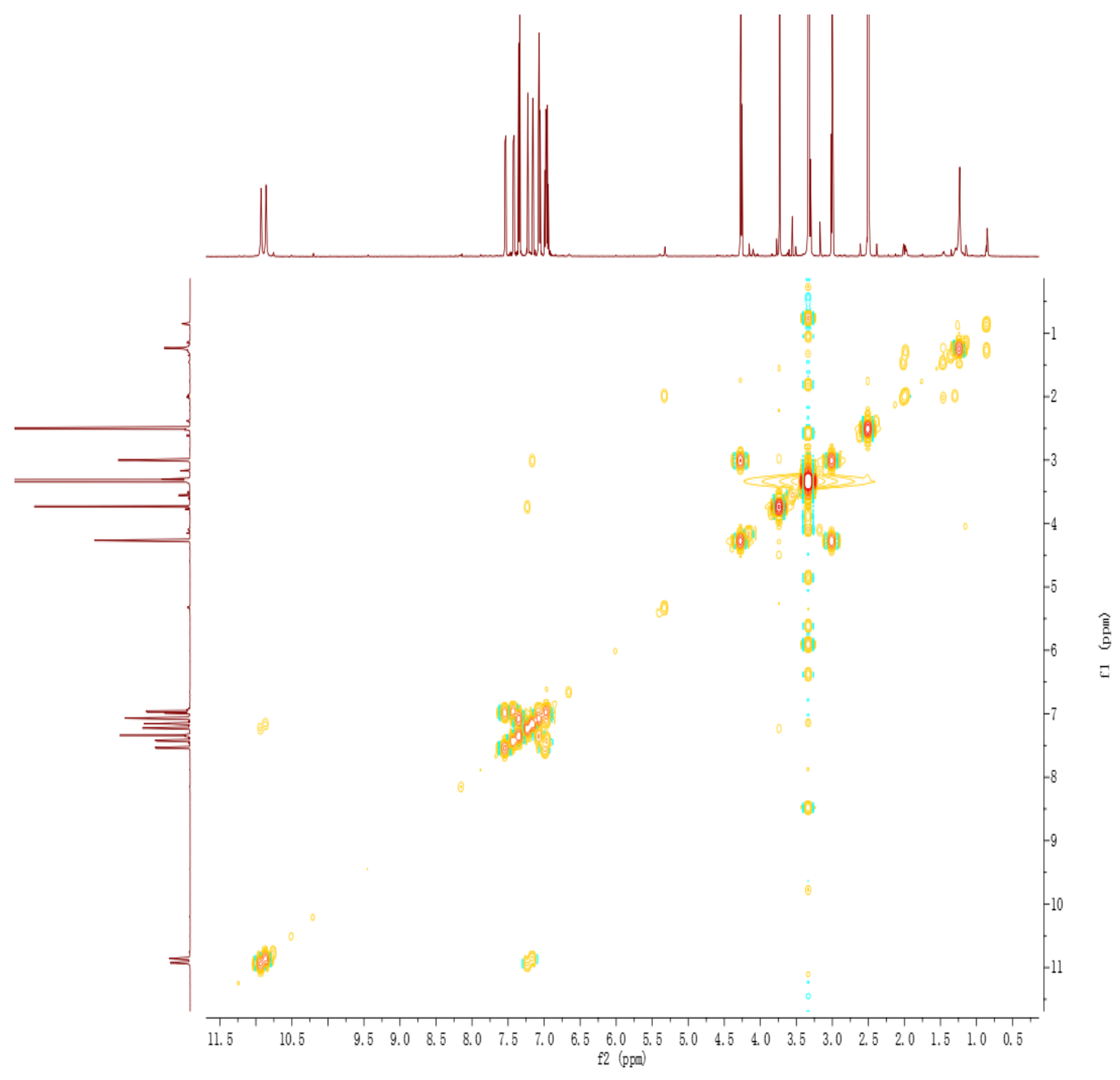

Figure S26. COSY spectrum of fusariumindole A (3) in DMSO- $d_{6}$ 
<smiles>O=C(Cc1c[nH]c2ccccc12)OCCc1c[nH]c2ccccc12</smiles>

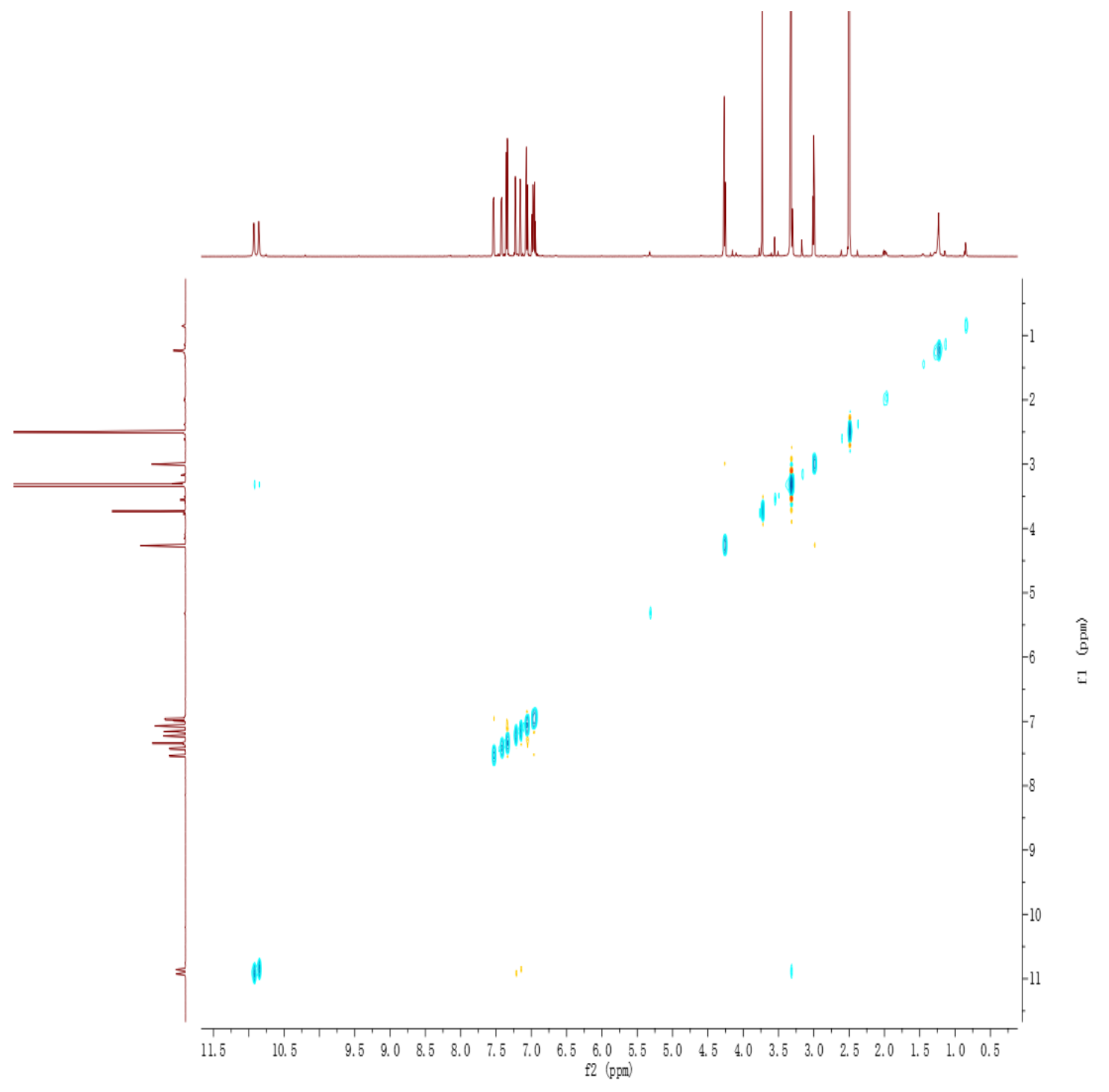

Figure S27. NOESY spectrum of fusariumindole A (3) in DMSO- $d_{6}$ 


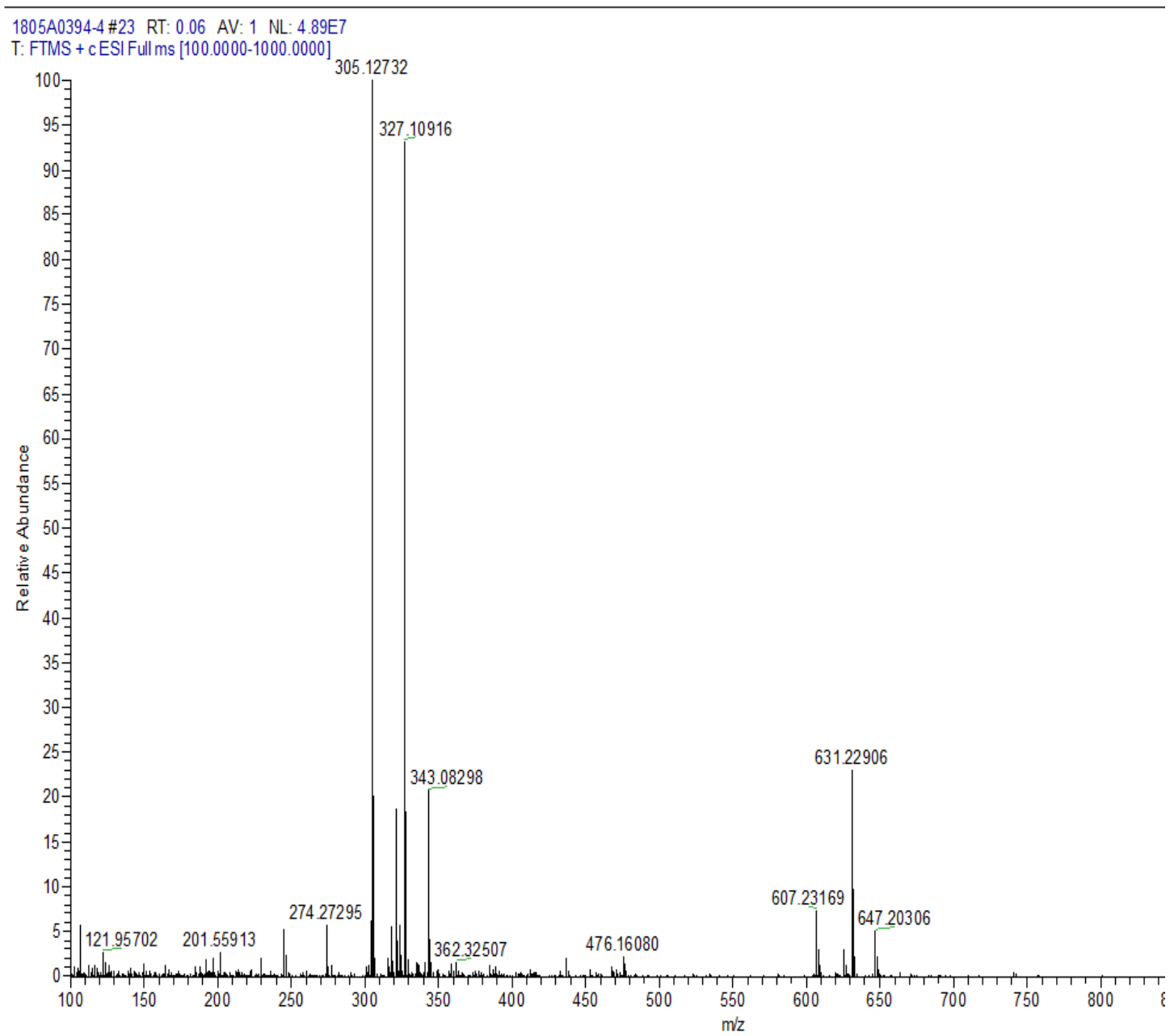

Figure S28. HR-ESIMS spectrum of fusariumindole B (4) 

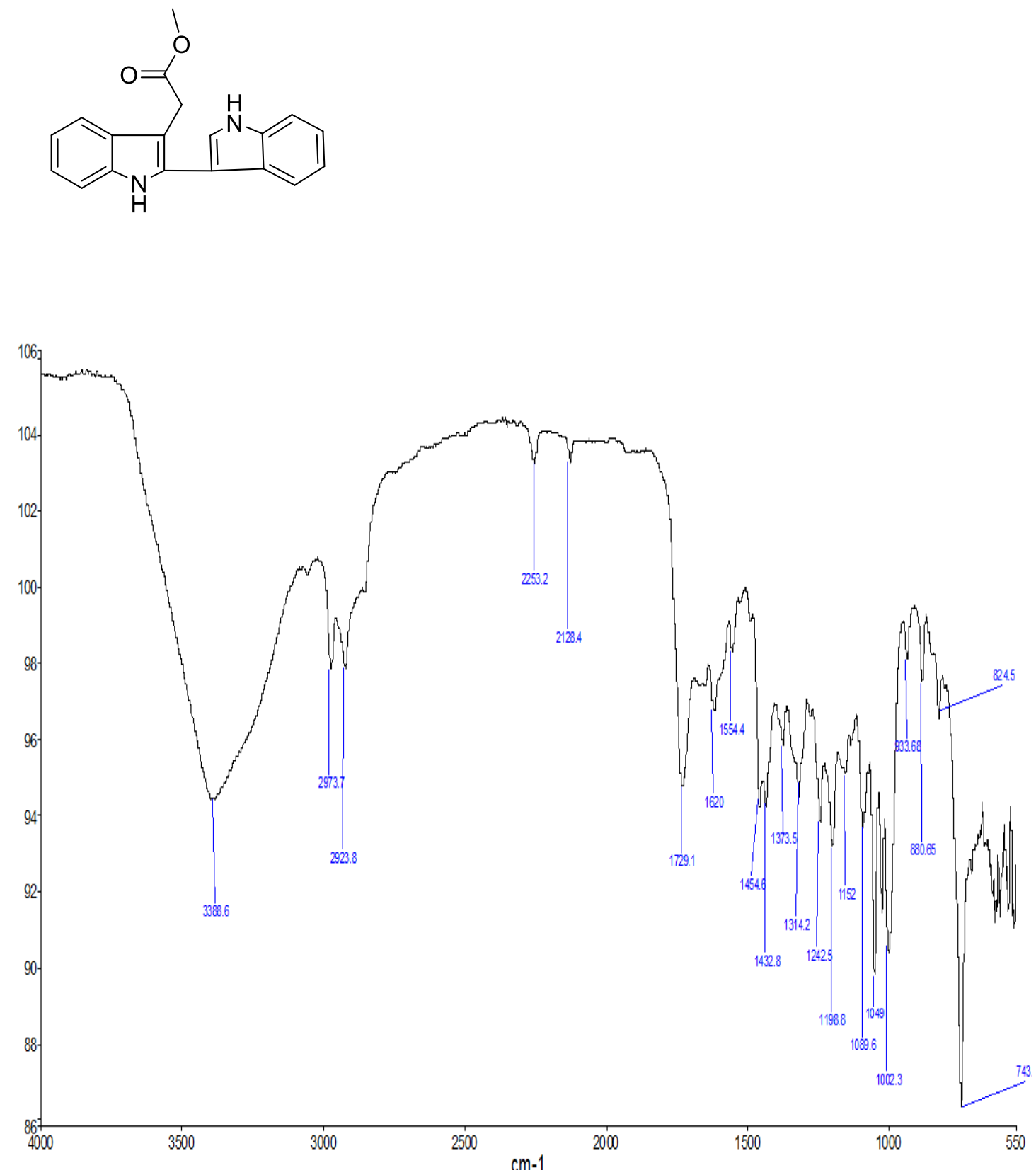

Figure S29. The IR spectrum of fusariumindole B (4) 
<smiles>COC(=O)Cc1c(-c2c[nH]c3ccccc23)[nH]c2ccccc12</smiles>

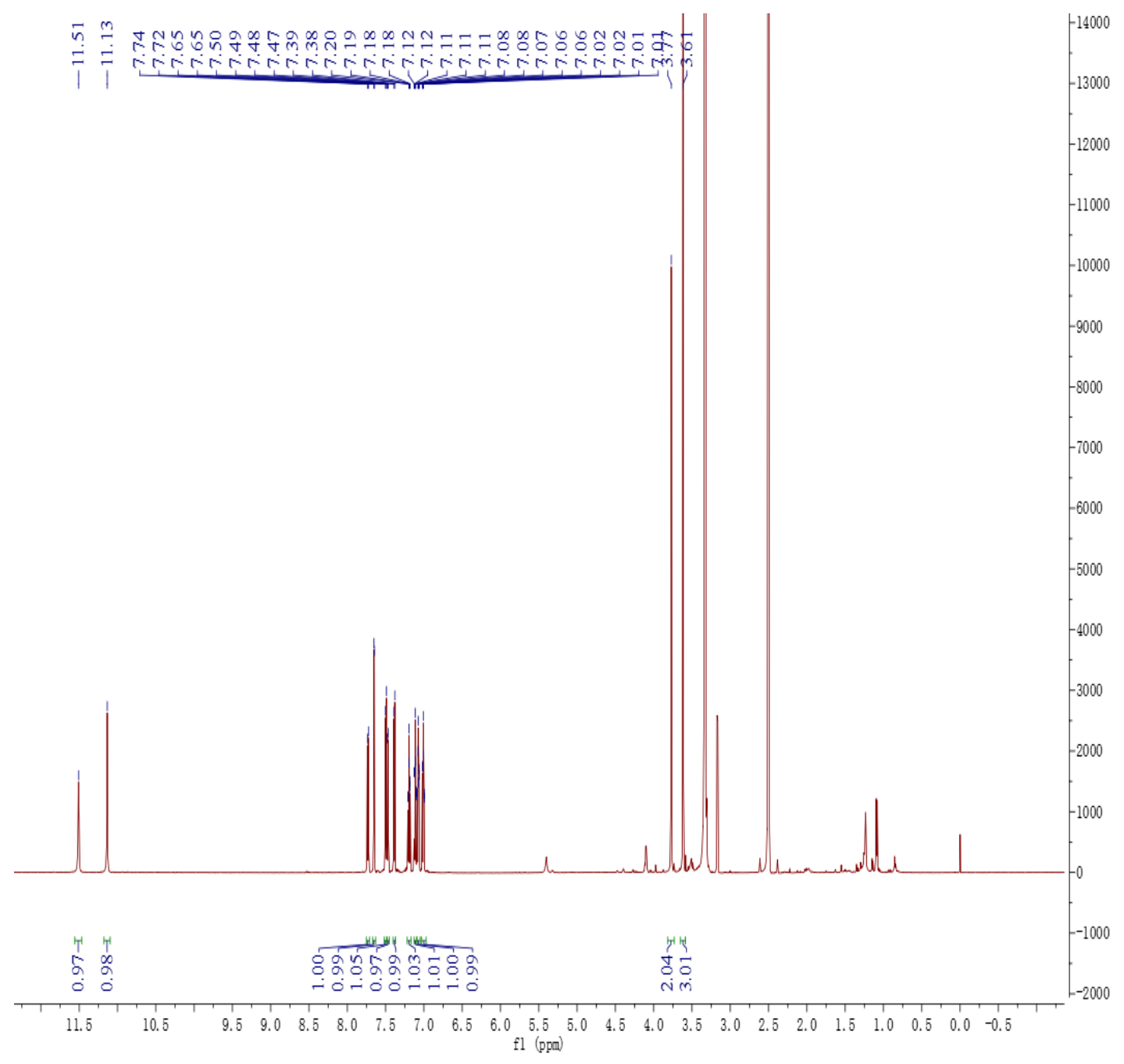

Figure S30. ${ }^{1} \mathrm{H}$ NMR spectrum of fusariumindole B (4) in DMSO- $d_{6}(600 \mathrm{MHz})$ 
<smiles>COC(=O)Cc1c(-c2c[nH]c3ccccc23)[nH]c2ccccc12</smiles>

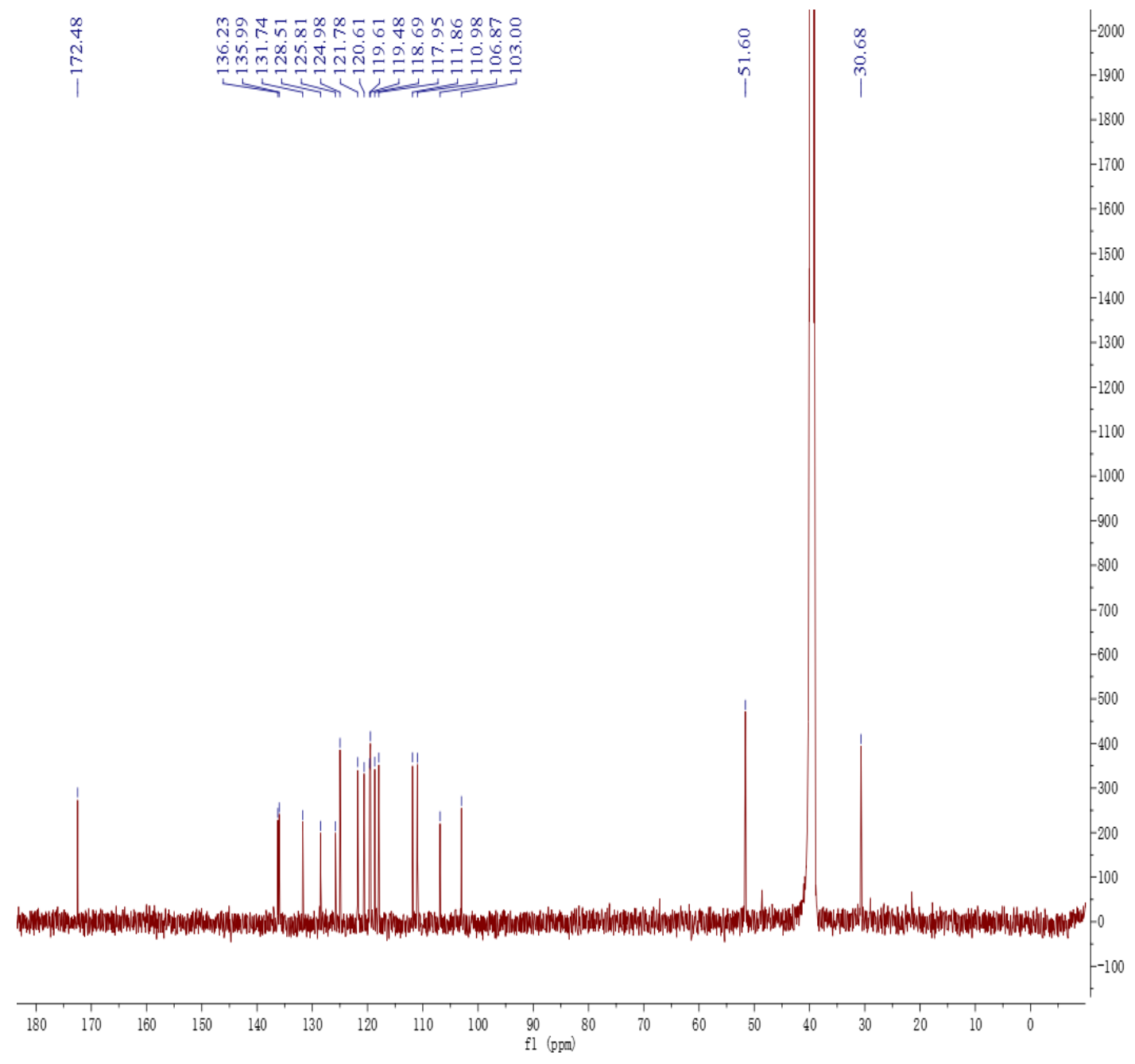

Figure S31. ${ }^{13} \mathrm{C}$ NMR spectrum of fusariumindole B (4) in DMSO- $d_{6}(150 \mathrm{MHz})$ 
<smiles>COC(=O)Cc1c(-c2c[nH]c3ccccc23)[nH]c2ccccc12</smiles>

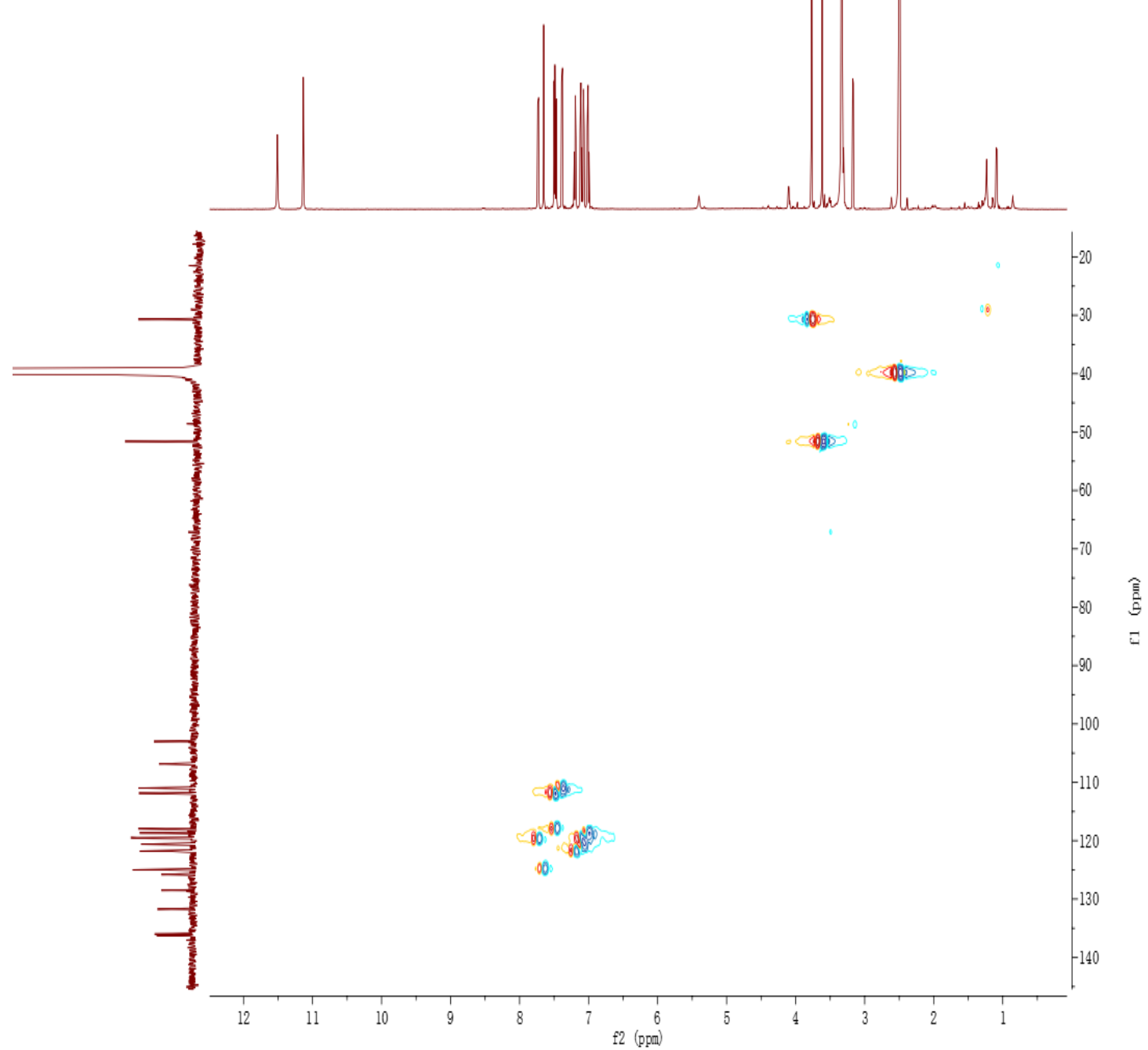

Figure S32. HMQC spectrum of fusariumindole B (4) in DMSO- $d_{6}$ 
<smiles>COC(=O)Cc1c(-c2c[nH]c3ccccc23)[nH]c2ccccc12</smiles>

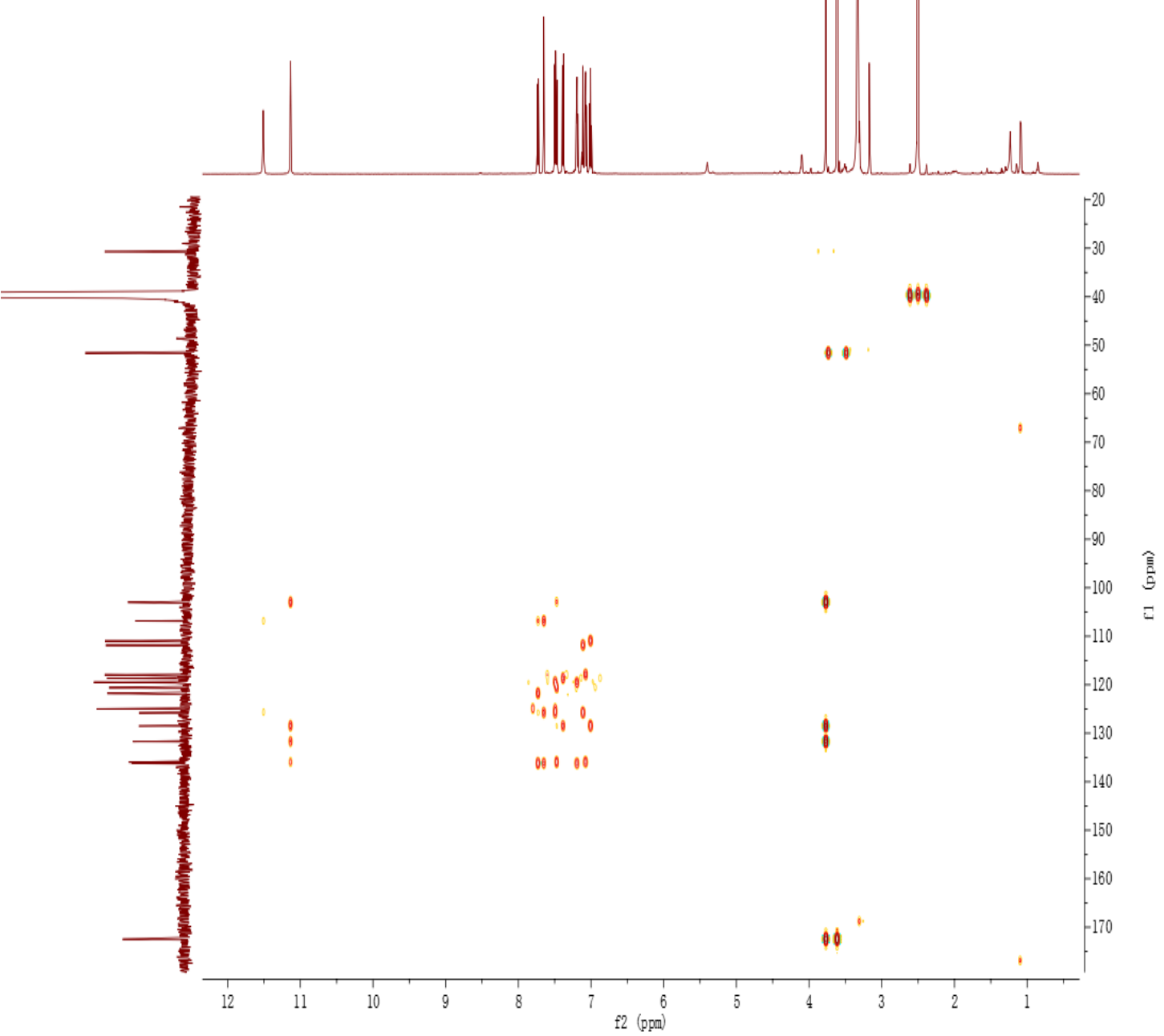

Figure S33. HMBC spectrum of fusariumindole B (4) in DMSO- $d_{6}$ 
<smiles>COC(=O)Cc1c(-c2c[nH]c3ccccc23)[nH]c2ccccc12</smiles>

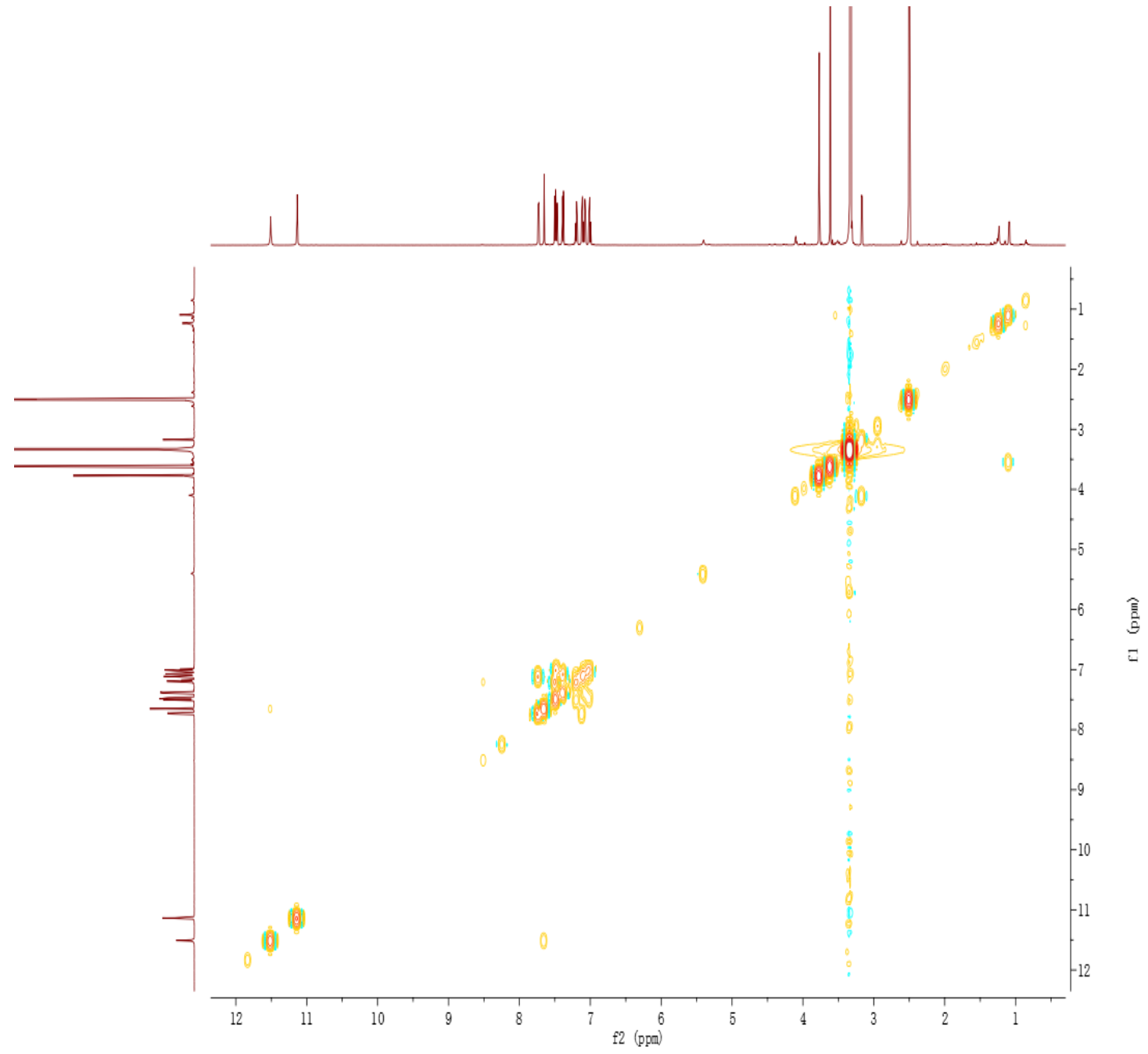

Figure S34. COSY spectrum of fusariumindole B (4) in DMSO- $d_{6}$ 

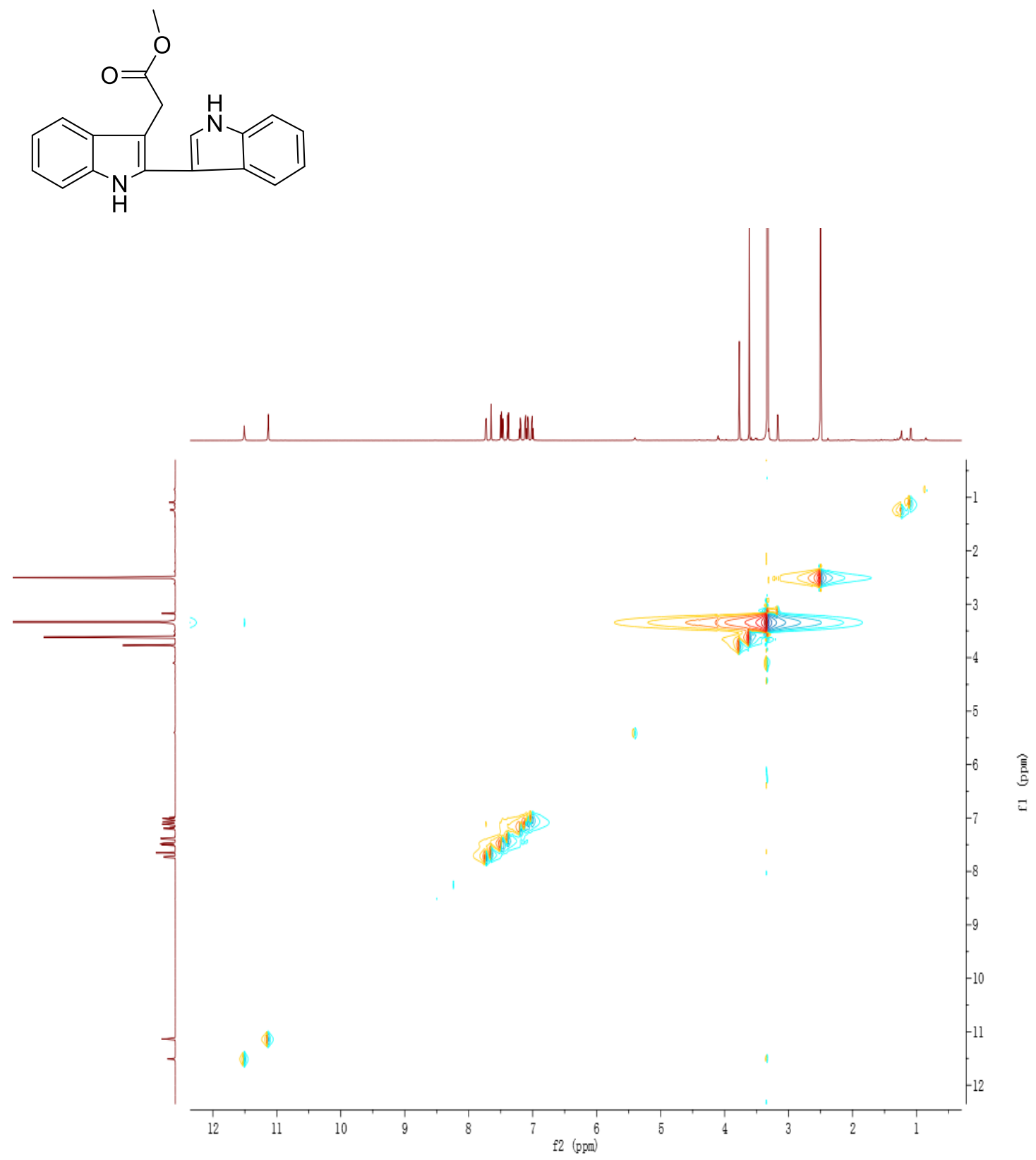

Figure S35. NOESY spectrum of fusariumindole B (4) in DMSO- $d_{6}$ 
Measured region for $308.0917 \mathrm{~m} / \mathrm{z}$

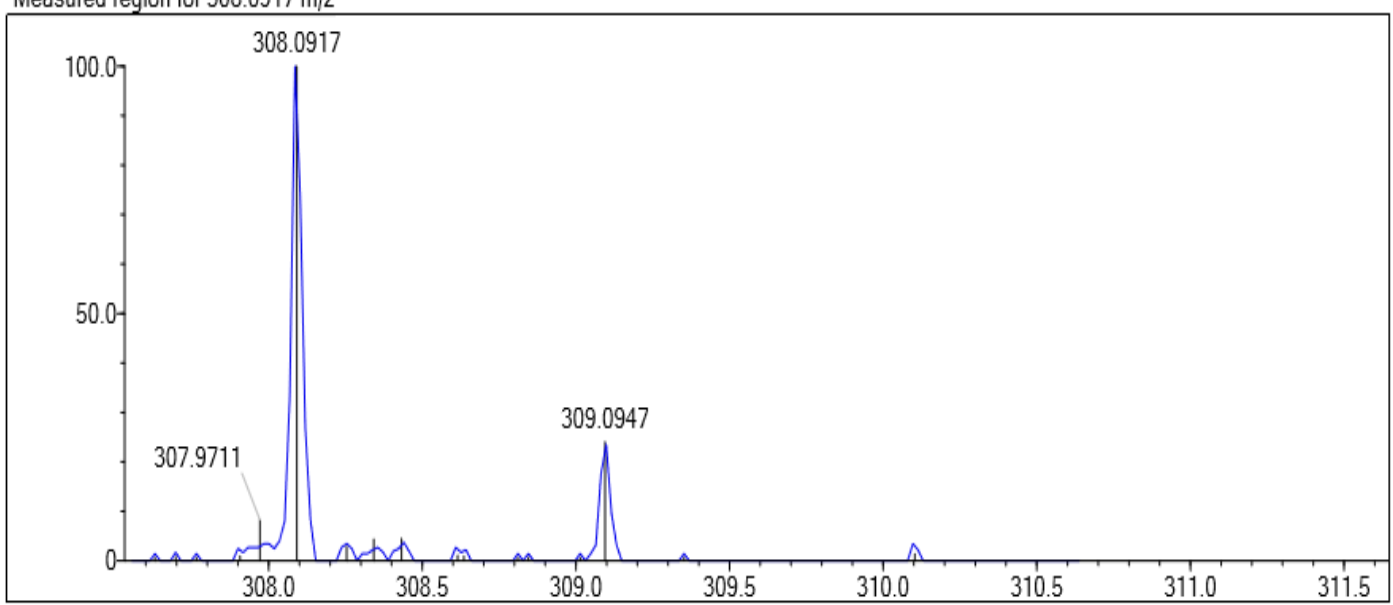

C18 H15 N 04 [M-H]- : Predicted region for $308.0928 \mathrm{~m} / 2$

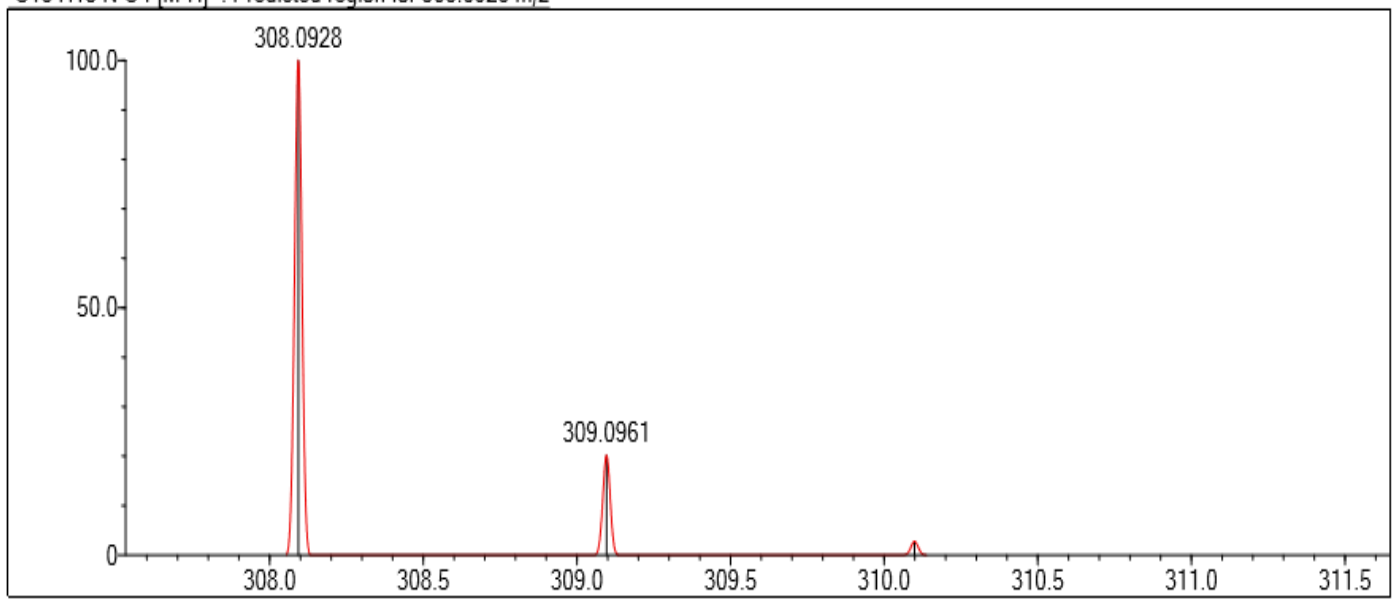

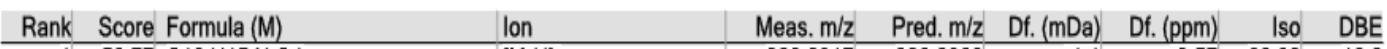

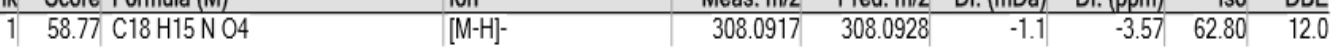

Figure S36. HR-ESIMS spectrum of fusariumindole C (5) 
<smiles>O=C(O[C@H](Cc1ccccc1)C(=O)O)c1c[nH]c2ccccc12</smiles>

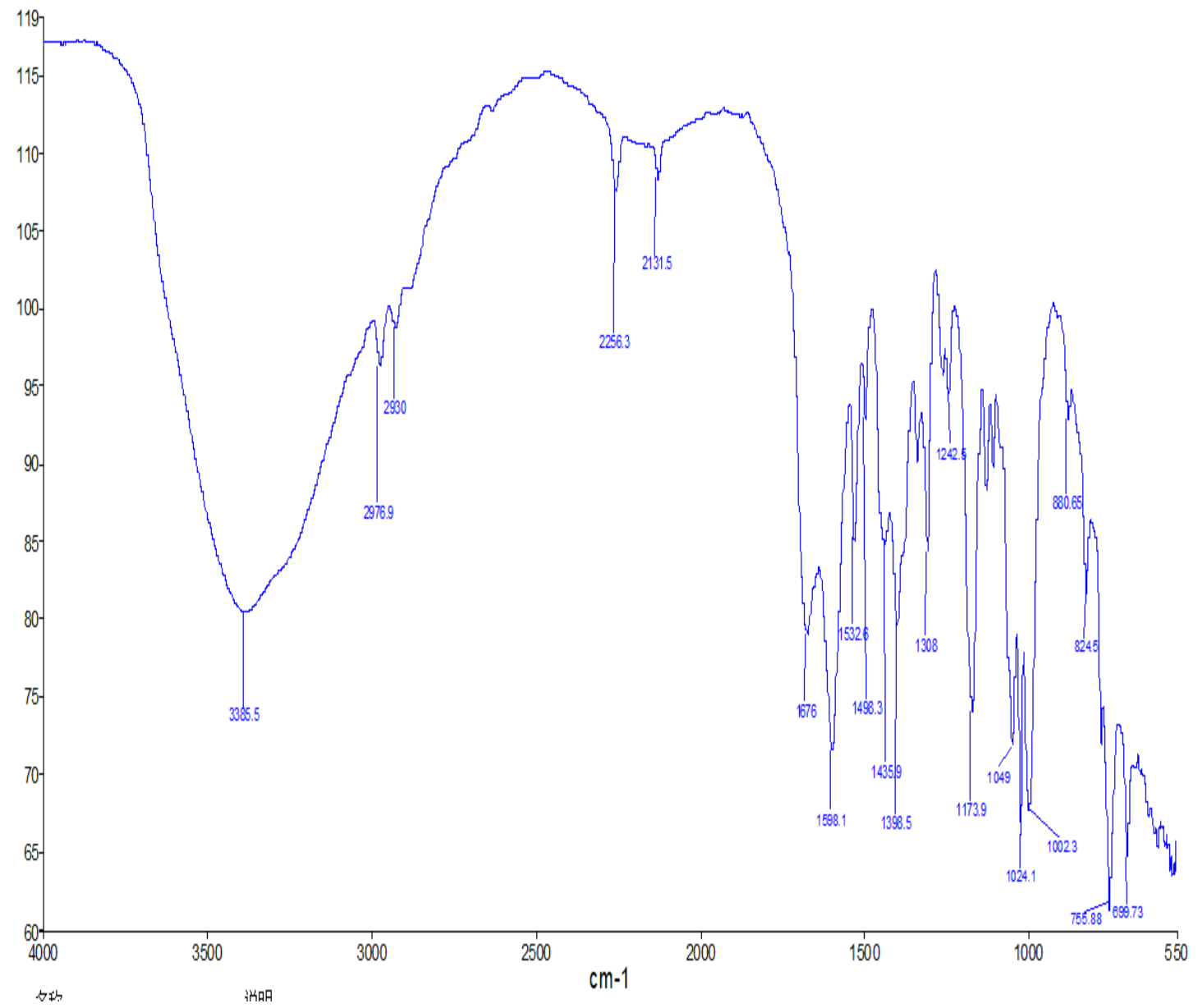

Figure S37. The IR spectrum of fusariumindole C (5) 
<smiles>O=C(OC(Cc1ccccc1)C(=O)O)c1c[nH]c2ccccc12</smiles>

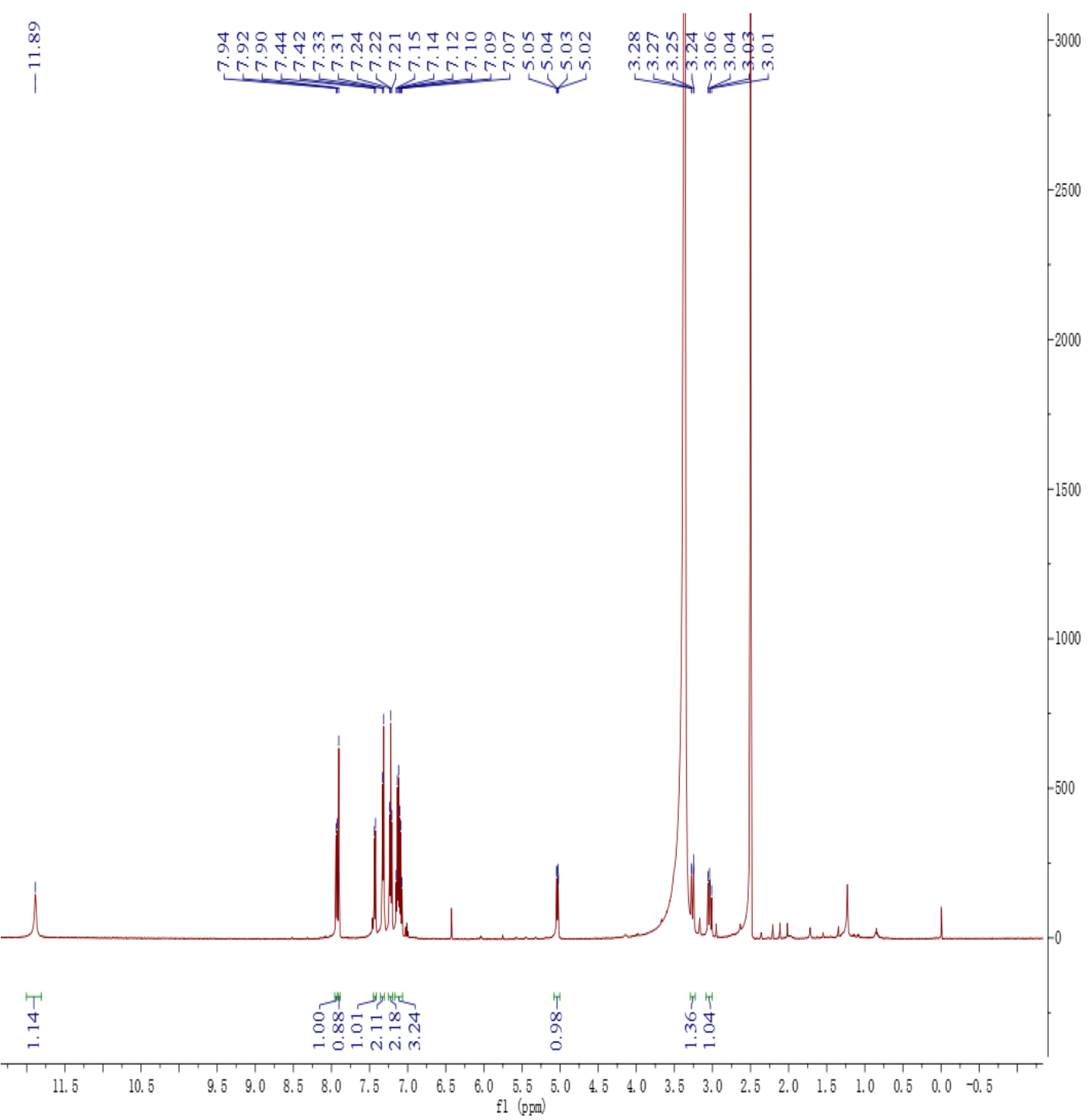

Figure S38. ${ }^{1} \mathrm{H}$ NMR spectrum of fusariumindole C (5) in DMSO- $d_{6}(400 \mathrm{MHz})$ 
<smiles>O=C(OC(Cc1ccccc1)C(=O)O)c1c[nH]c2ccccc12</smiles>

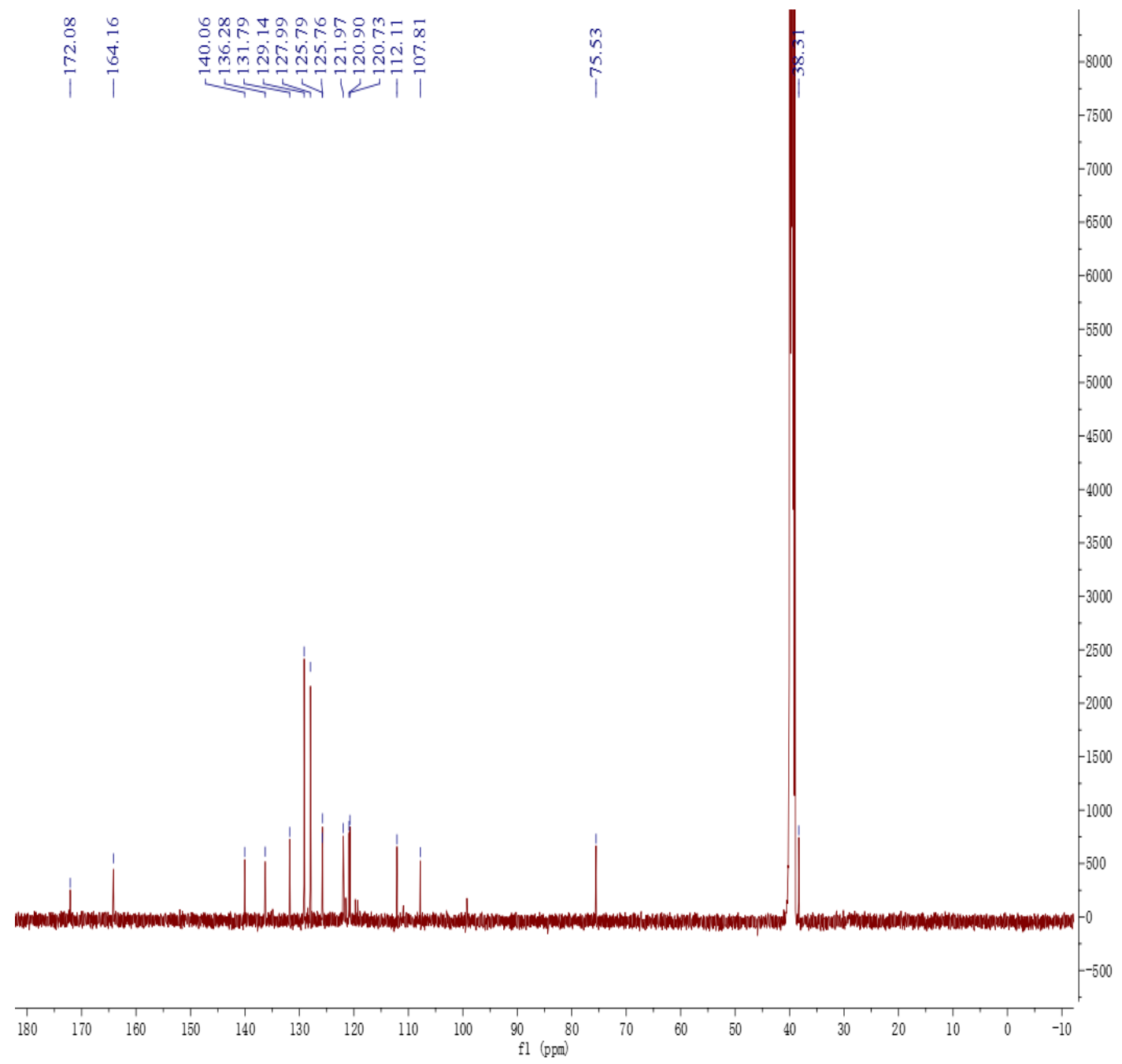

Figure S39. ${ }^{13} \mathrm{C}$ NMR spectrum of fusariumindole C (5) in DMSO- $d_{6}(100 \mathrm{MHz})$ 
<smiles>O=C(O[C@H](Cc1ccccc1)C(=O)O)c1c[nH]c2ccccc12</smiles>
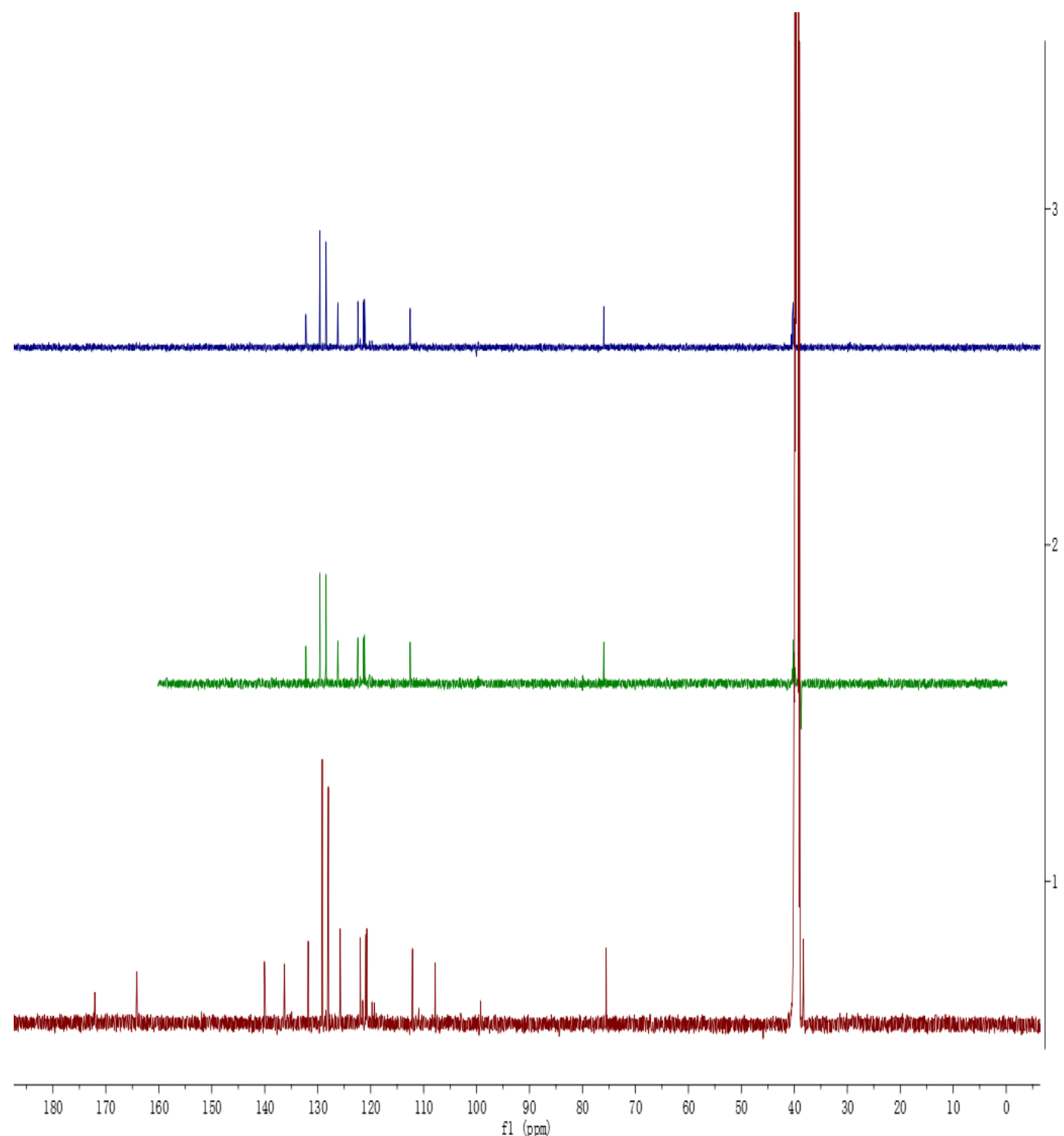

Figure S40. DEPT 90 and DEPT 135 spectra of fusariumindole C (5) in DMSO- $d_{6}$ 
<smiles>O=C(O[C@H](Cc1ccccc1)C(=O)O)c1c[nH]c2ccccc12</smiles>

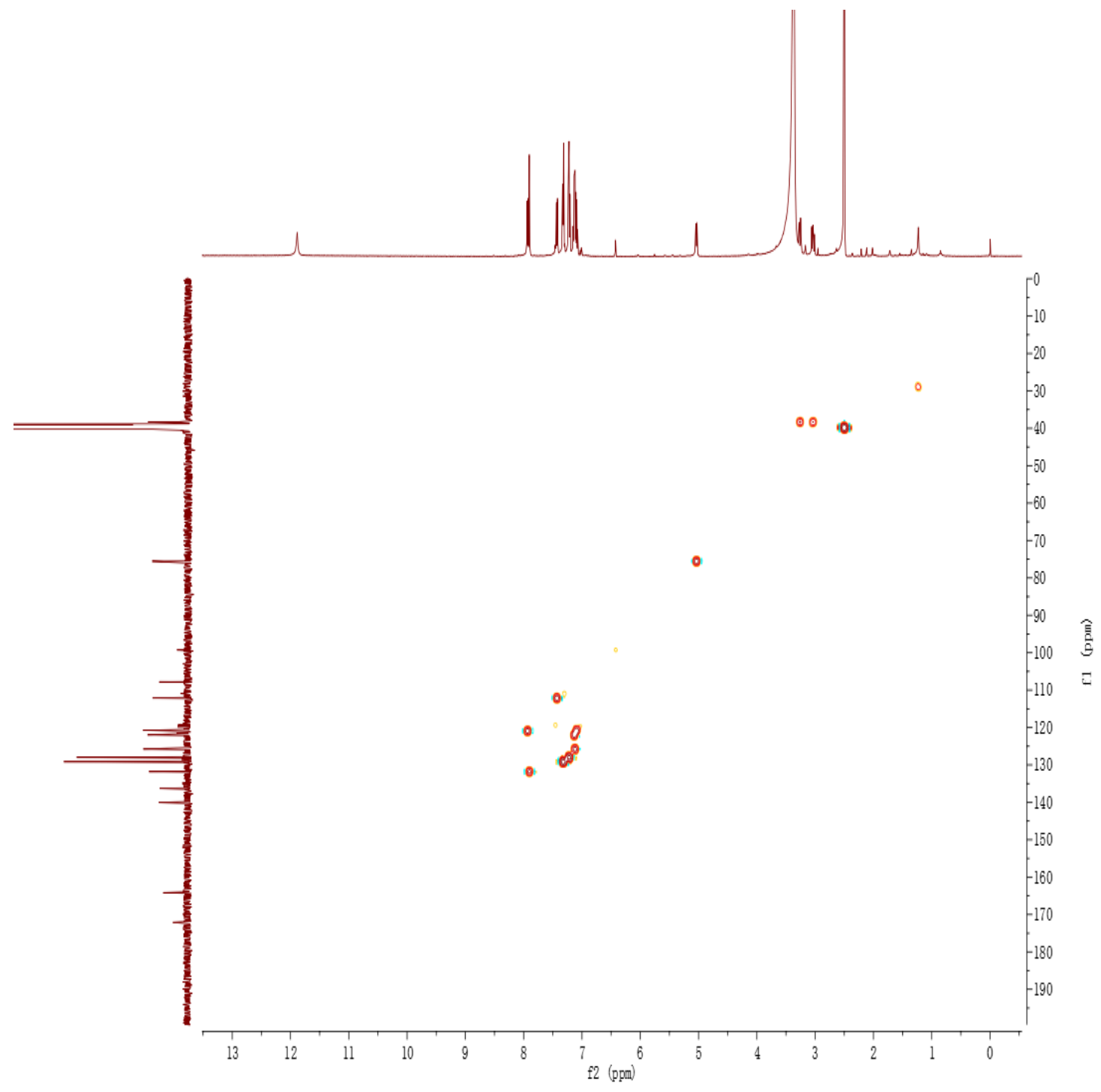

Figure S41. HMQC spectrum of fusariumindole C (5) in DMSO- $d_{6}$ 
<smiles>O=C(O[C@H](Cc1ccccc1)C(=O)O)c1c[nH]c2ccccc12</smiles>

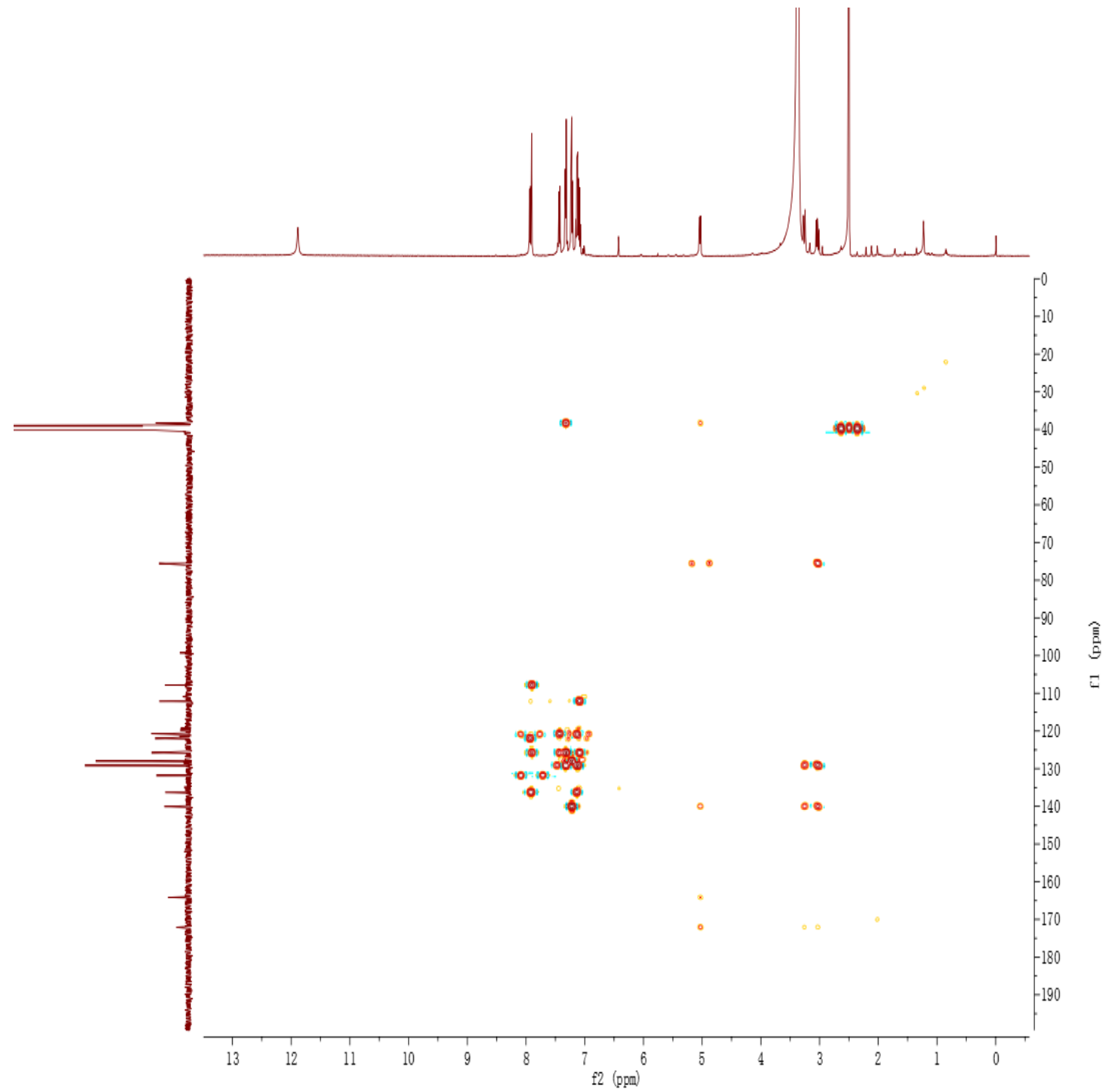

Figure S42. HMBC spectrum of fusariumindole C (5) in DMSO- $d_{6}$ 
<smiles>O=C(O[C@H](Cc1ccccc1)C(=O)O)c1c[nH]c2ccccc12</smiles>

$\mathrm{H}$

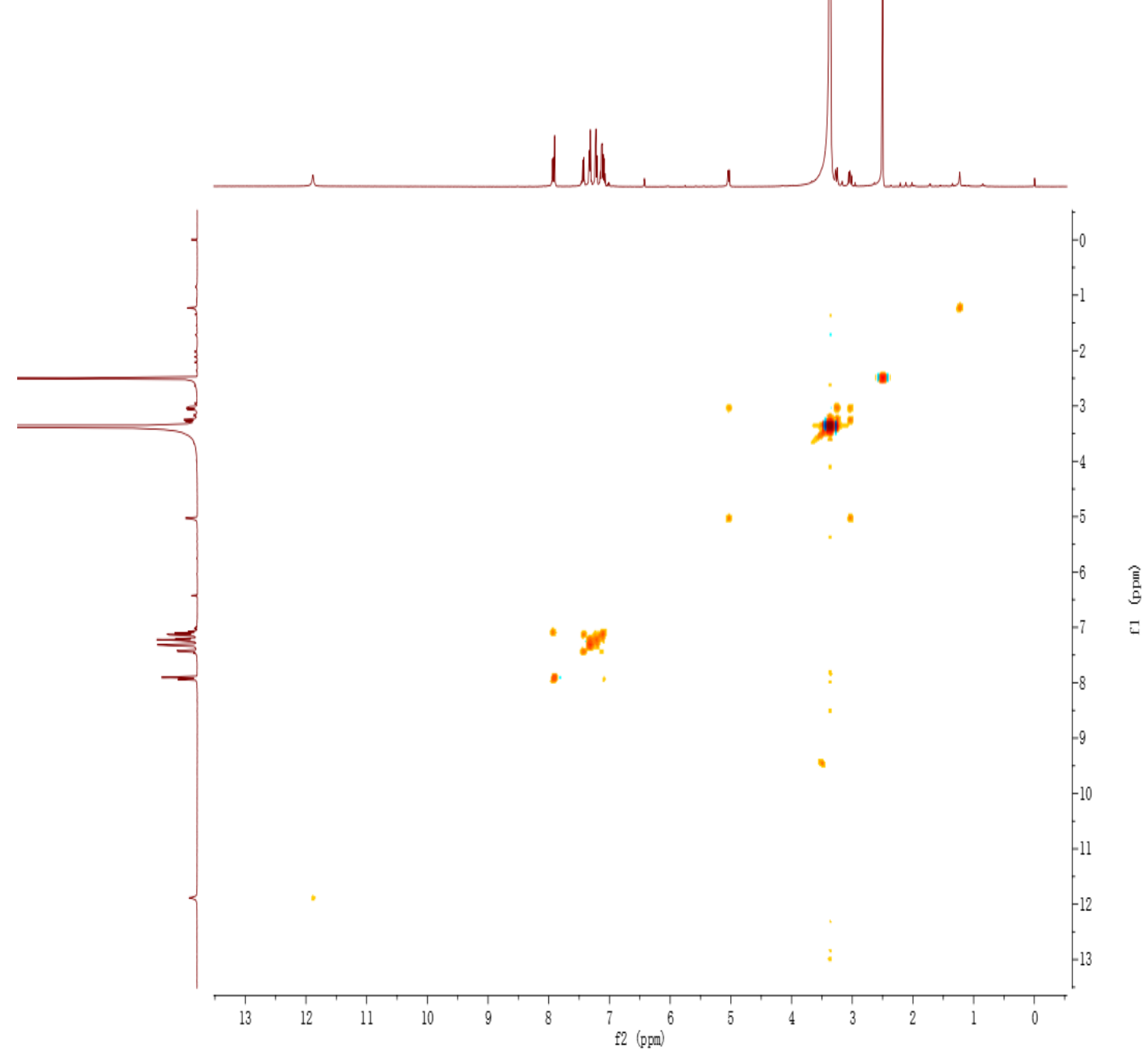

Figure S43. COSY spectrum of fusariumindole C (5) in DMSO- $d_{6}$ 
<smiles>O=C(O[C@H](Cc1ccccc1)C(=O)O)c1c[nH]c2ccccc12</smiles>

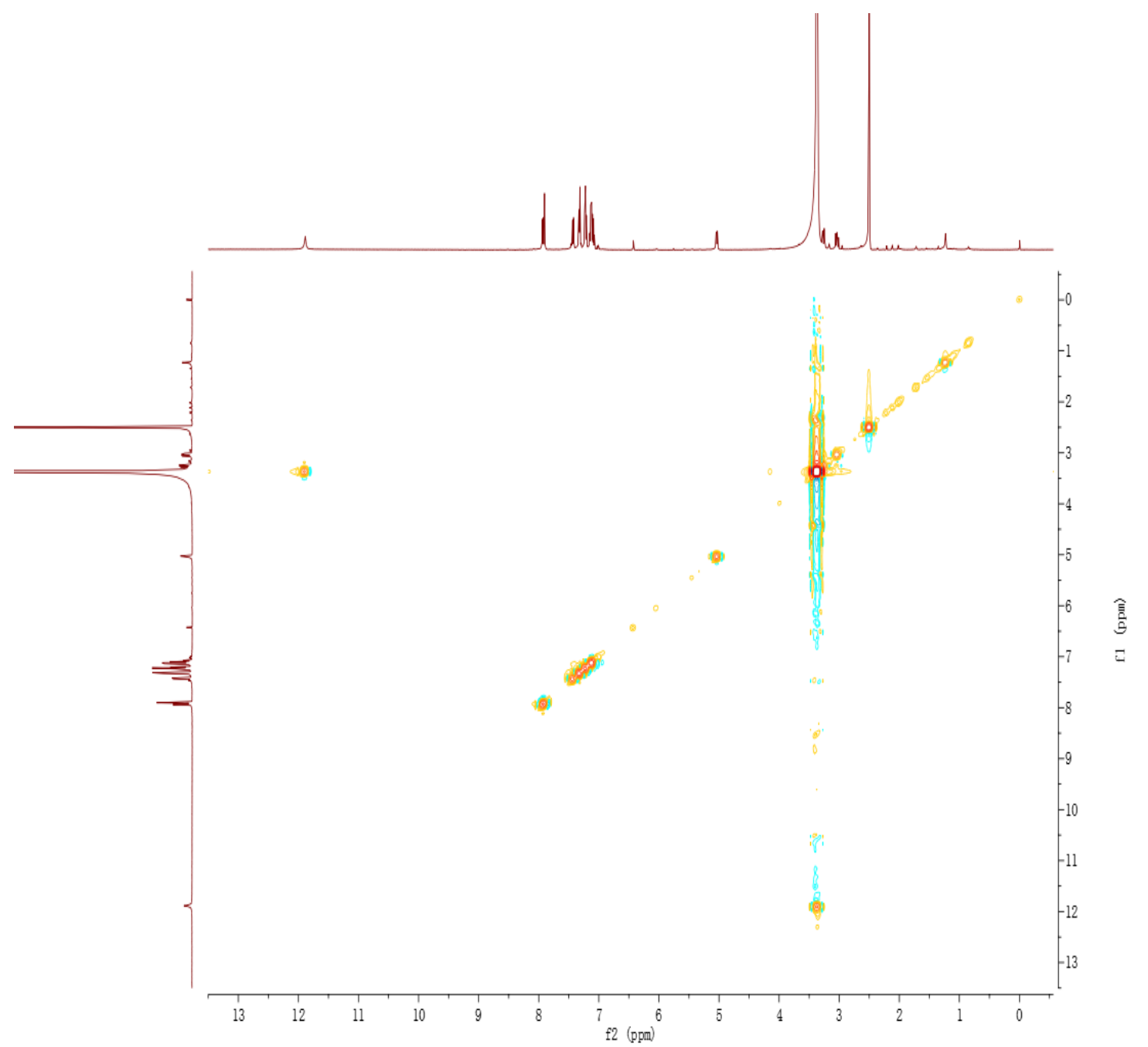

Figure S44. NOESY spectrum of fusariumindole C (5) in DMSO- $d_{6}$ 
Measured region for $270.1106 \mathrm{~m} / \mathrm{z}$

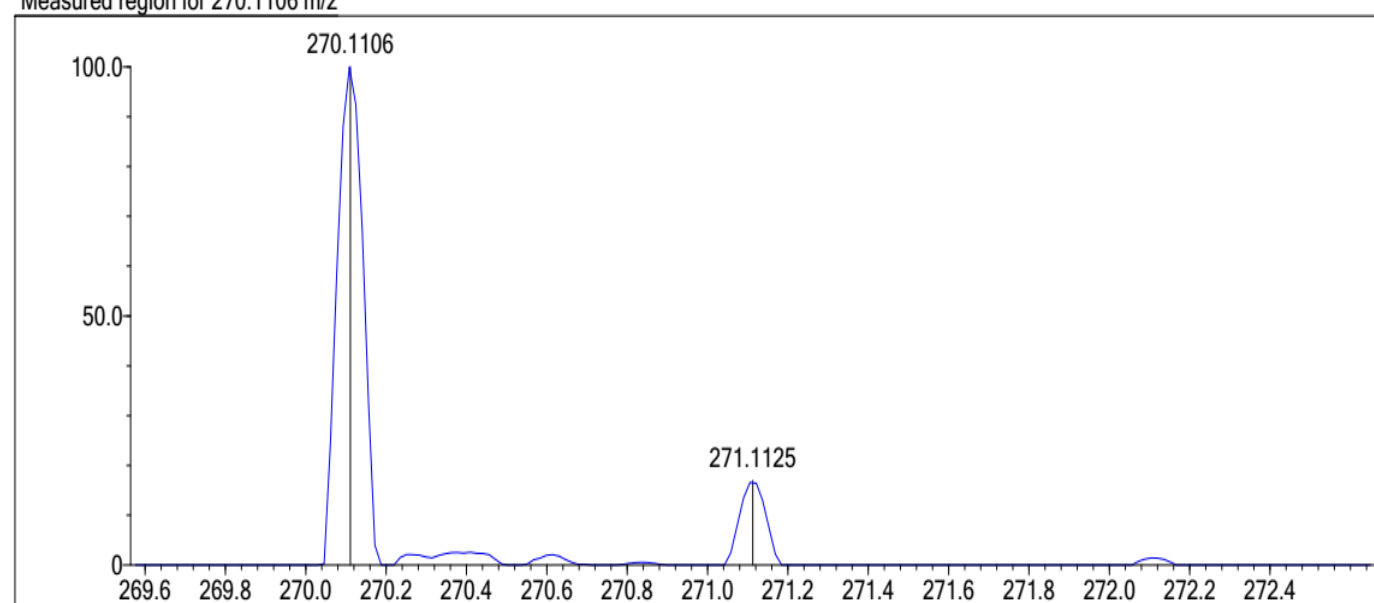

C14 H17 N O3 [M+Na]+ : Predicted region for $270.1101 \mathrm{~m} / \mathrm{z}$

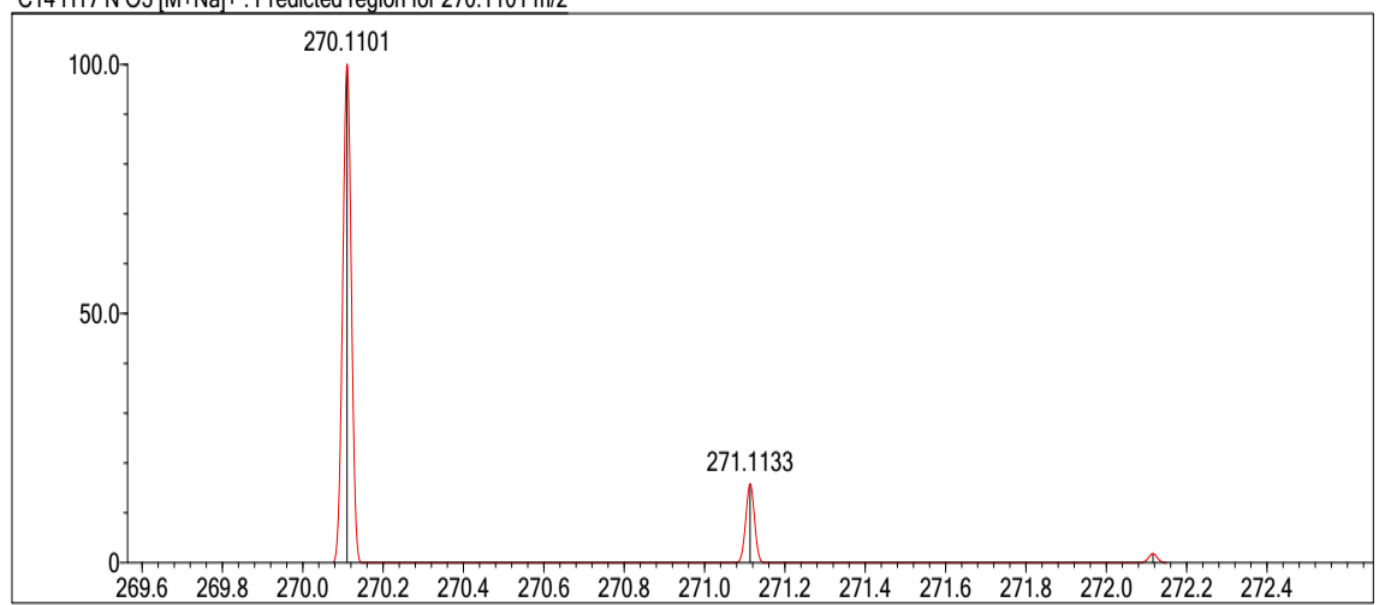

Figure S45. HR-ESIMS spectrum of ( \pm )-isoalternatine A(6) 
<smiles>CC(OC(=O)Cc1c[nH]c2ccccc12)[C@@H](C)O</smiles>

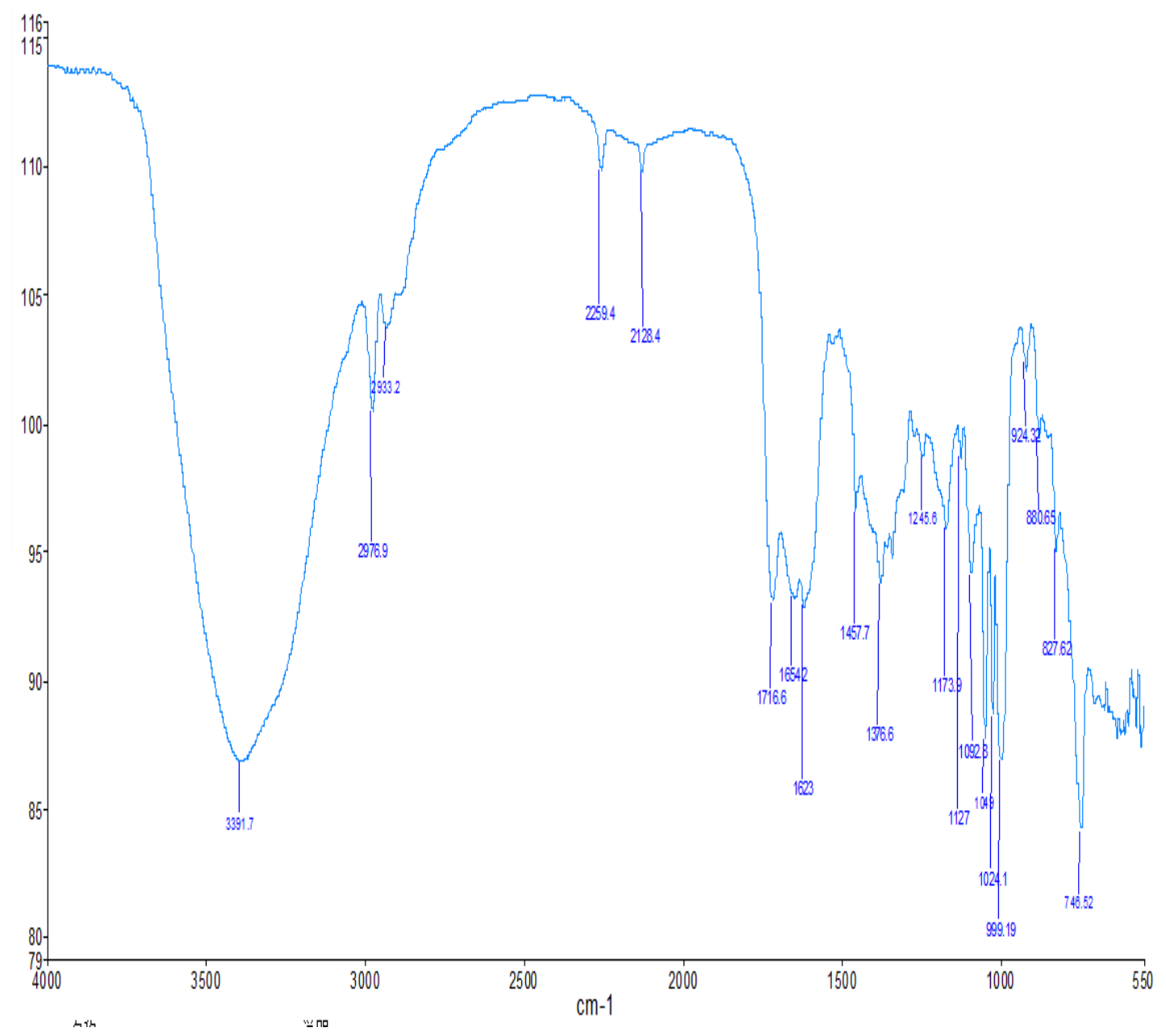

Figure S46. The IR spectrum of $( \pm)$-isoalternatine $\mathrm{A}(\mathbf{6})$ 
<smiles>C[C@H](O)[C@H](C)OC(=O)Cc1c[nH]c2ccccc12</smiles>

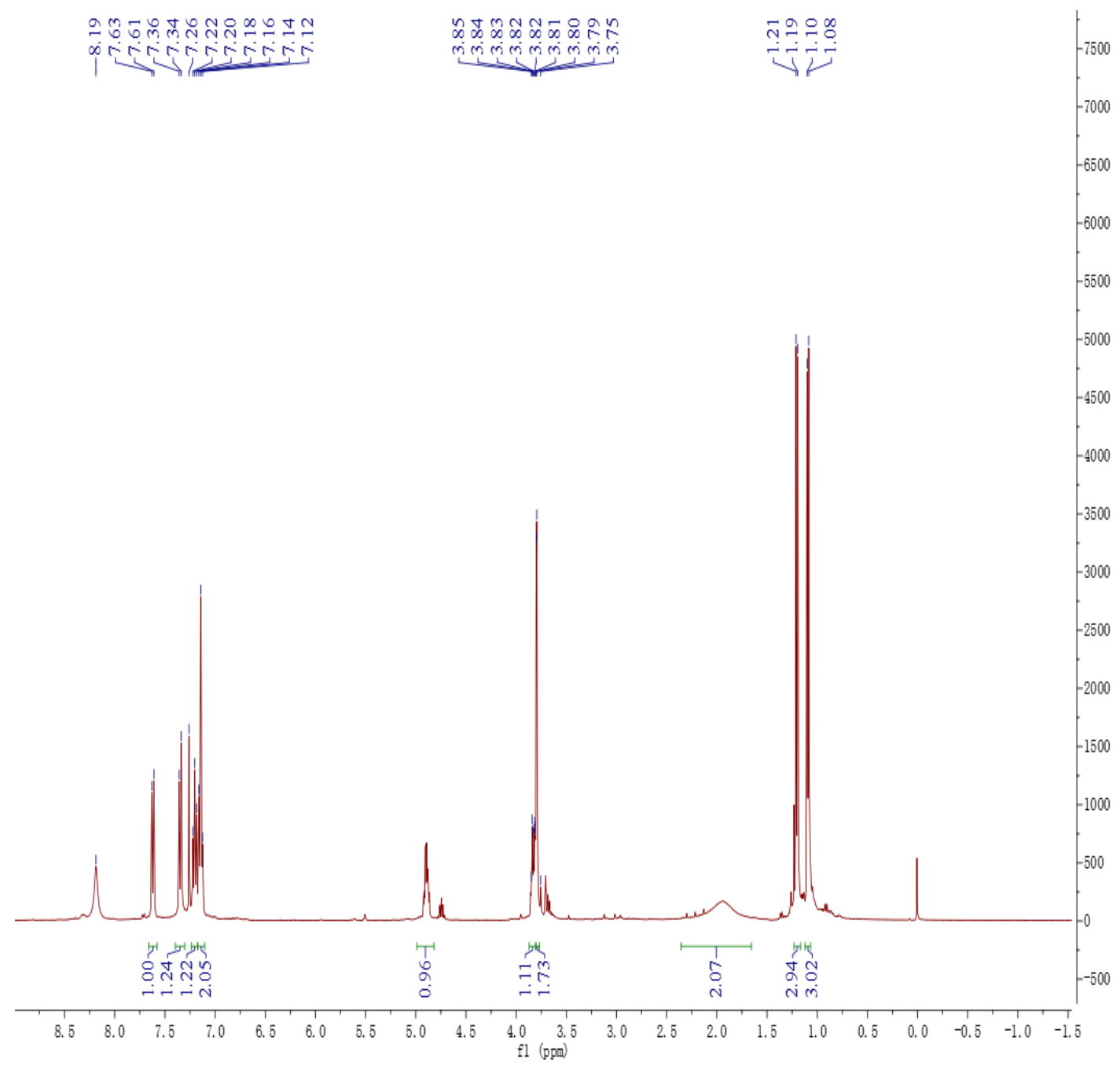

Figure S47. ${ }^{1} \mathrm{H}$ NMR spectrum of $( \pm)$-isoalternatine $\mathrm{A}(\mathbf{6})$ in $\mathrm{CDCl}_{3}(400 \mathrm{MHz})$ 
<smiles>CC(OC(=O)Cc1c[nH]c2ccccc12)[C@@H](C)O</smiles>

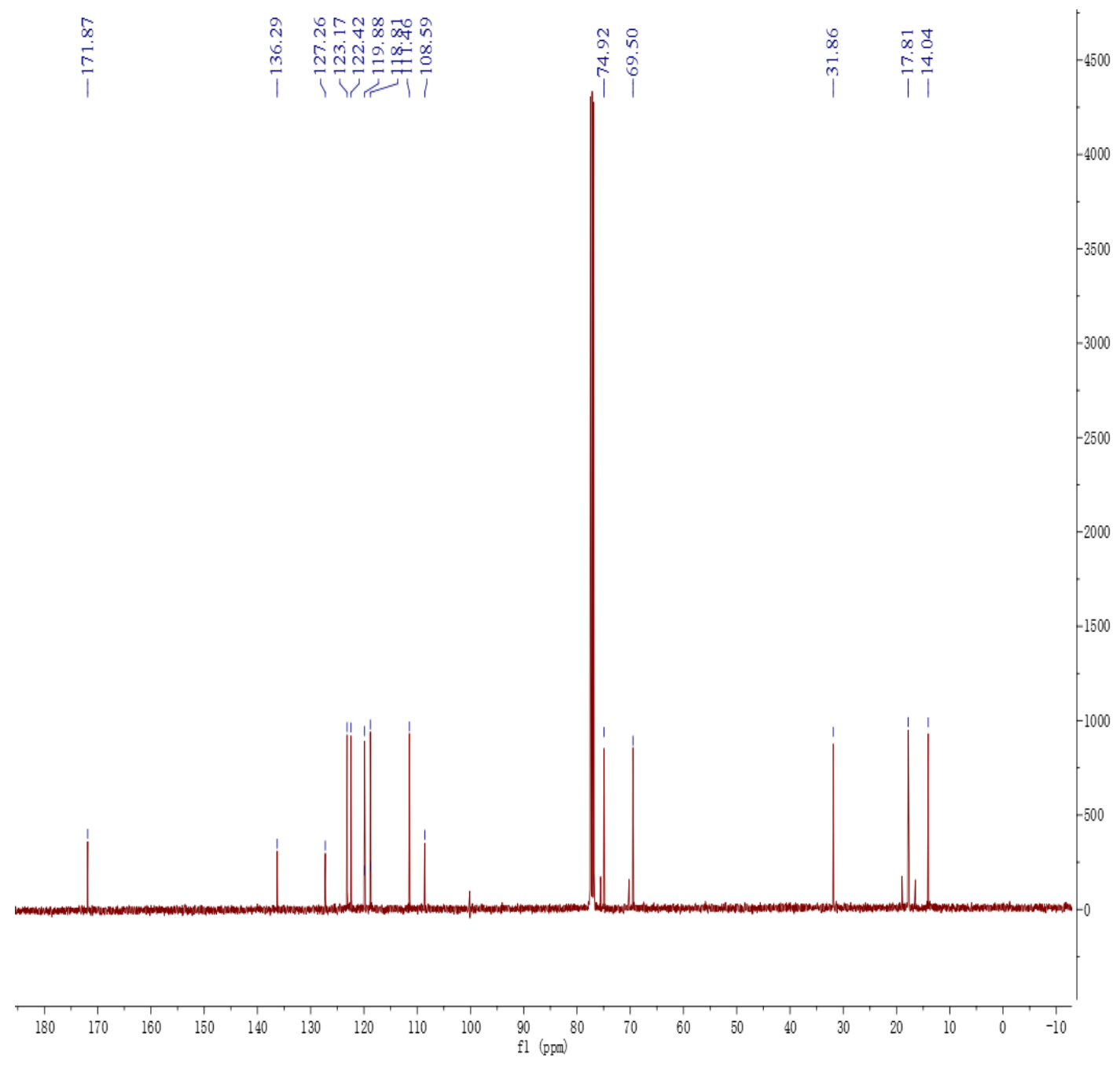

Figure $\mathrm{S} 48 .{ }^{13} \mathrm{C}$ NMR spectrum of $( \pm)$-isoalternatine $\mathrm{A}(\mathbf{6})$ in $\mathrm{CDCl}_{3}(100 \mathrm{MHz})$ 
<smiles>CC(OC(=O)Cc1c[nH]c2ccccc12)[C@@H](C)O</smiles>

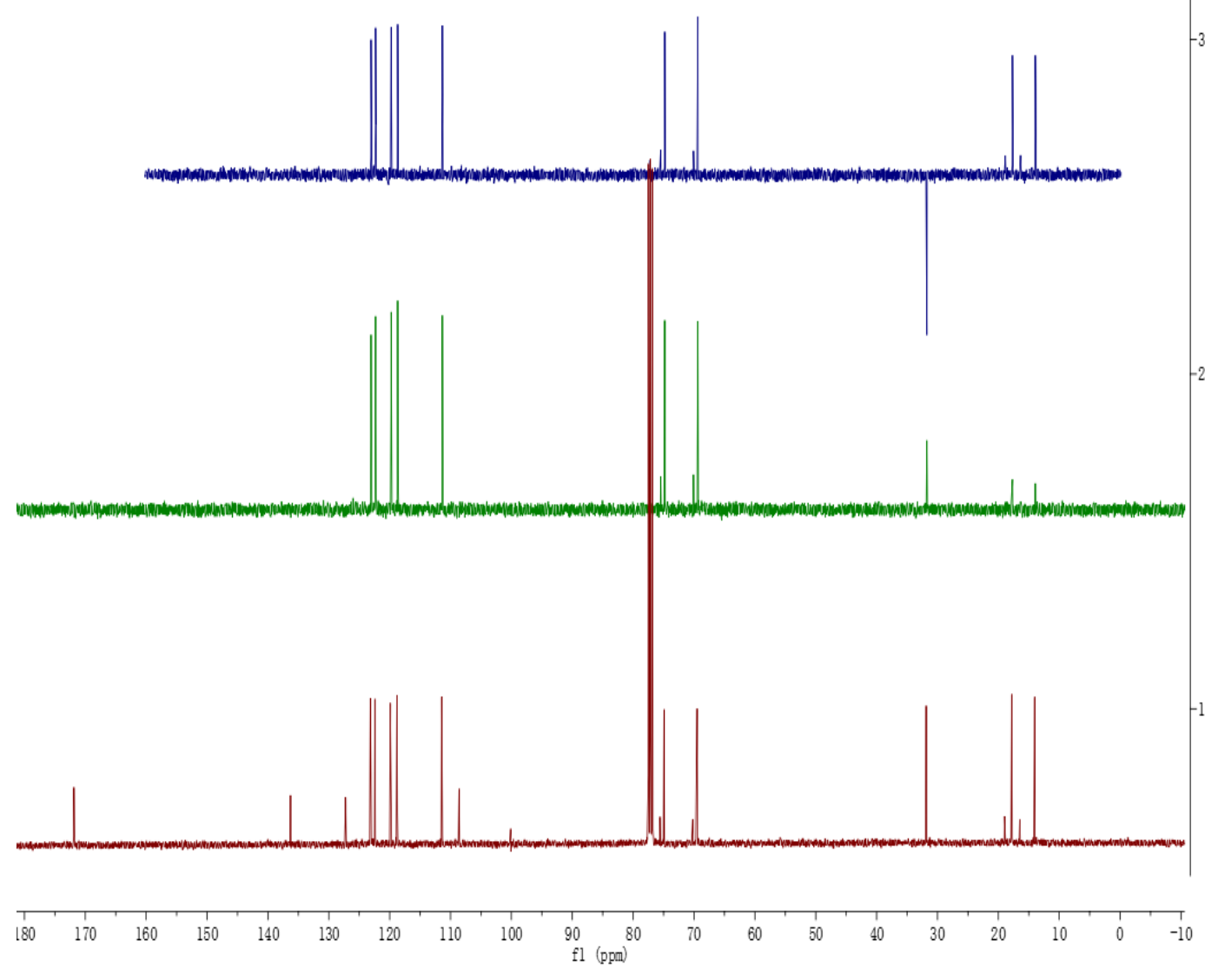

Figure S49. DEPT 90 and DEPT 135 spectra of $( \pm)$-isoalternatine $\mathrm{A}(\mathbf{6})$ in $\mathrm{CDCl}_{3}$ 
<smiles>CC(OC(=O)Cc1c[nH]c2ccccc12)[C@@H](C)O</smiles>

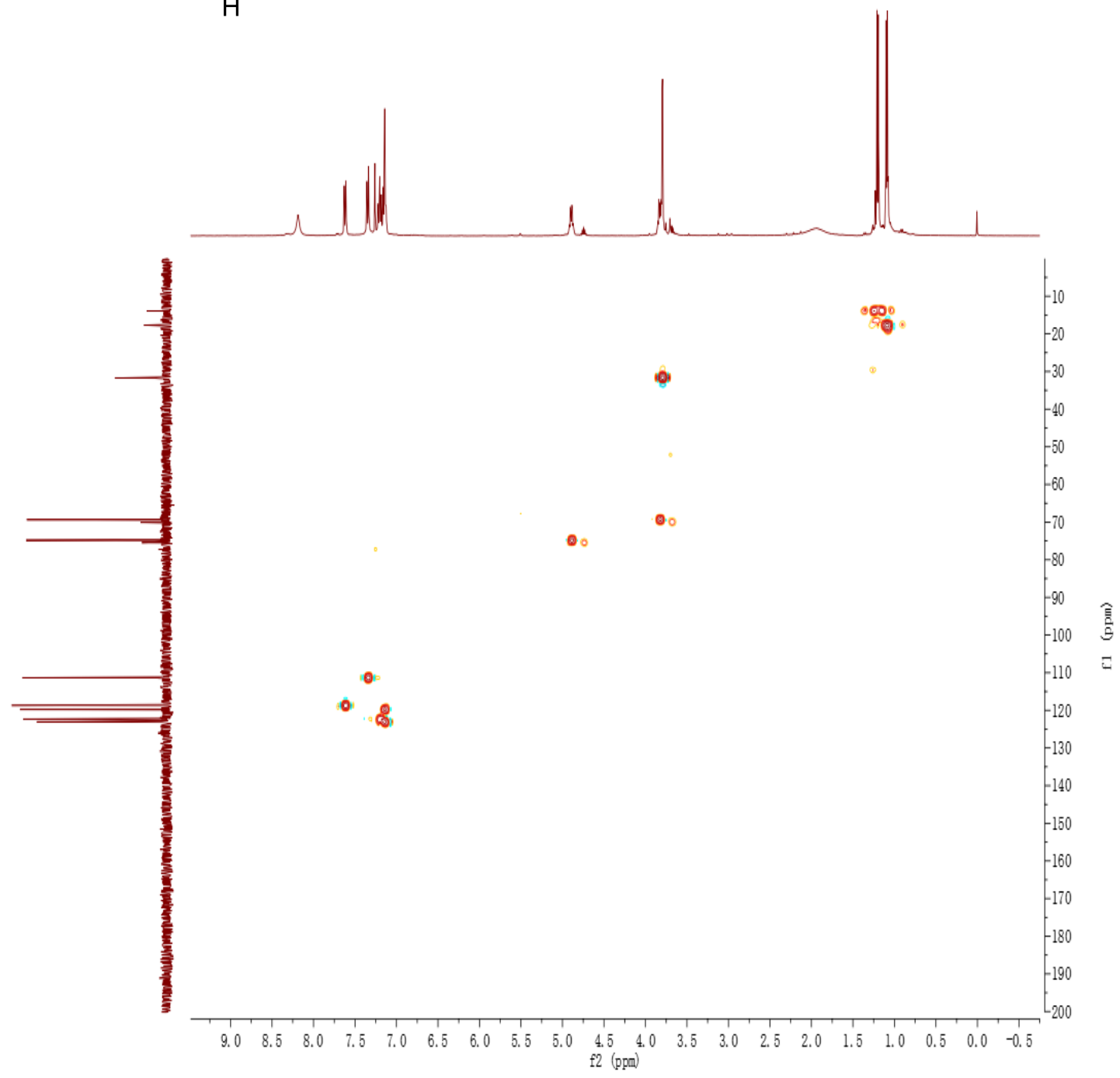

Figure S50. HMQC spectrum of ( \pm )-isoalternatine $\mathrm{A}(\mathbf{6})$ in $\mathrm{CDCl}_{3}$ 


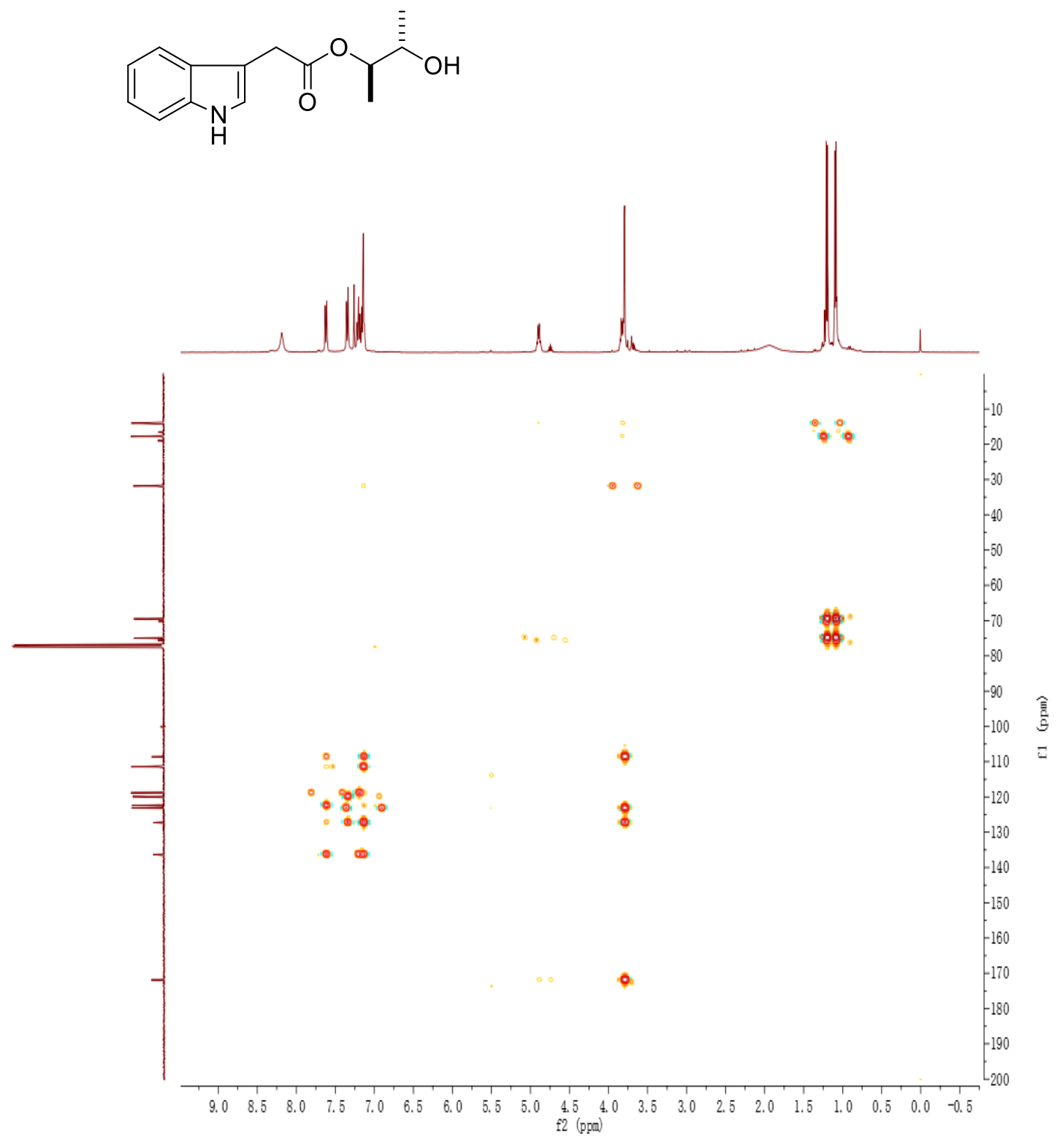

Figure S51. HMBC spectrum of ( \pm )-isoalternatine $\mathrm{A}(\mathbf{6})$ in $\mathrm{CDCl}_{3}$ 
<smiles>CC(O)[C@H](C)OC(=O)Cc1c[nH]c2ccccc12</smiles>

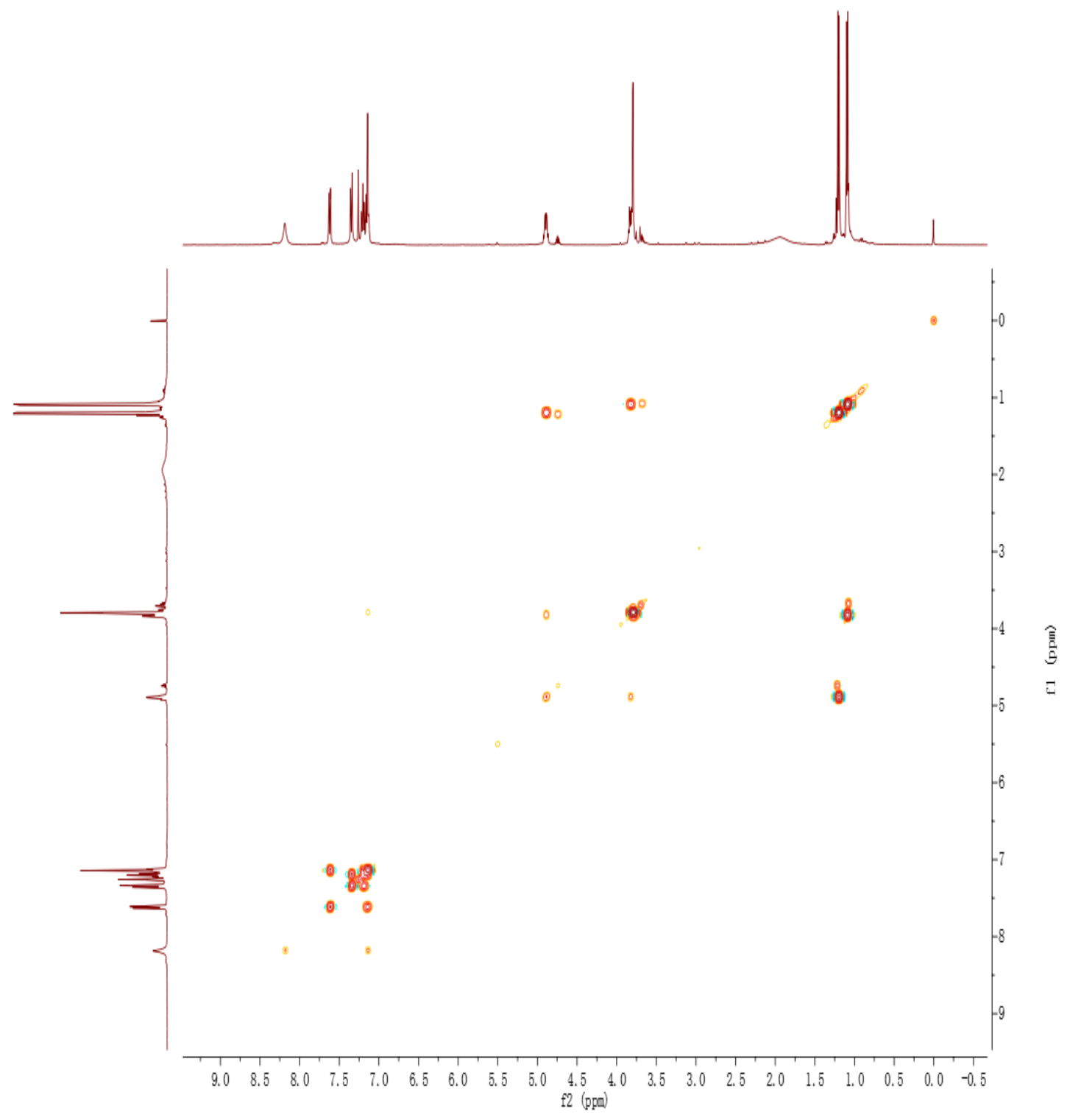

Figure S52. COSY spectrum of ( \pm )-isoalternatine $\mathrm{A}(\mathbf{6})$ in $\mathrm{CDCl}_{3}$ 
<smiles>CC(OC(=O)Cc1c[nH]c2ccccc12)[C@@H](C)O</smiles>

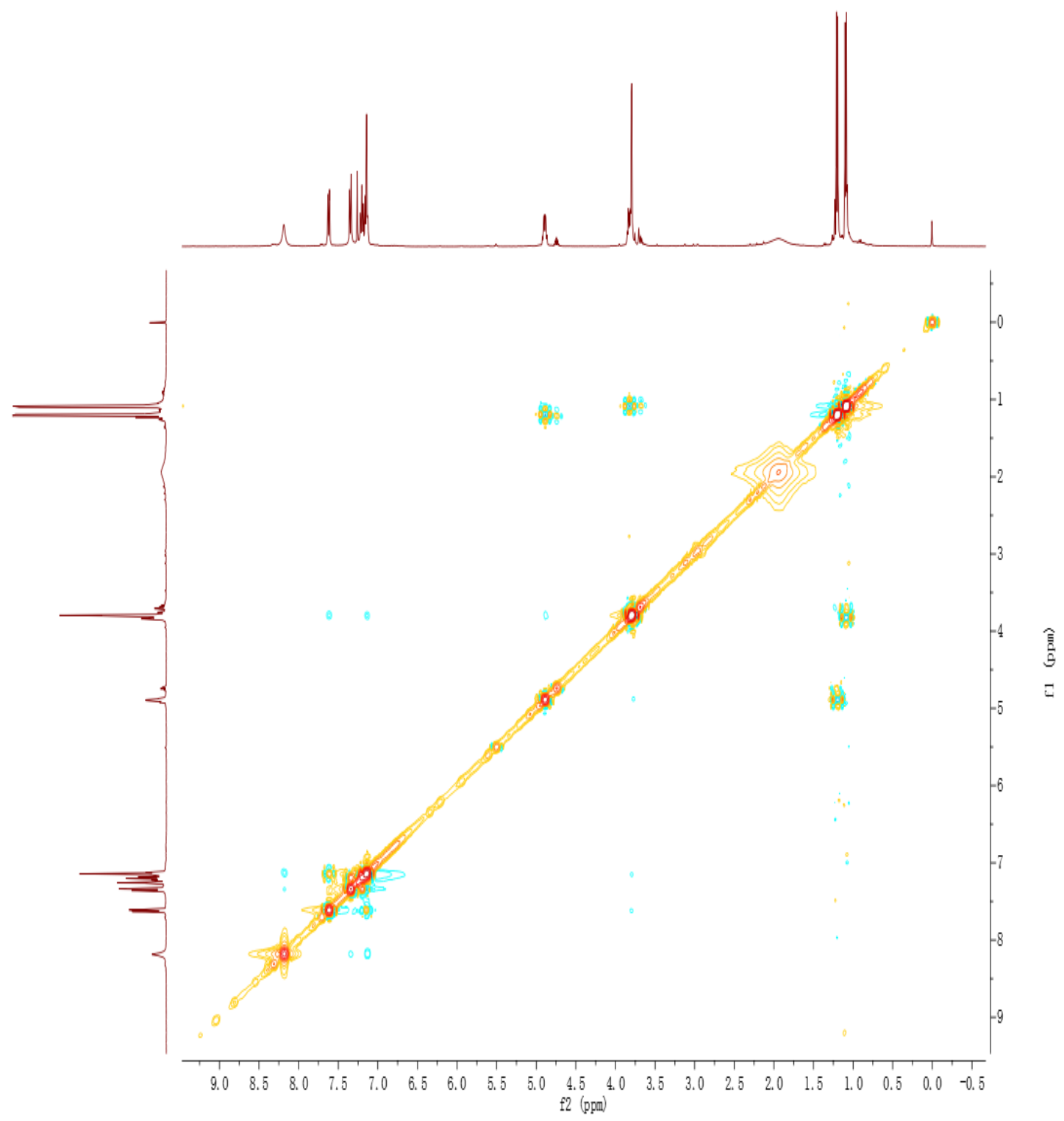

Figure S53. NOESY spectrum of ( \pm )-isoalternatine $\mathrm{A}(\mathbf{6})$ in $\mathrm{CDCl}_{3}$ 
Measured region for $270.1099 \mathrm{~m} / \mathrm{z}$

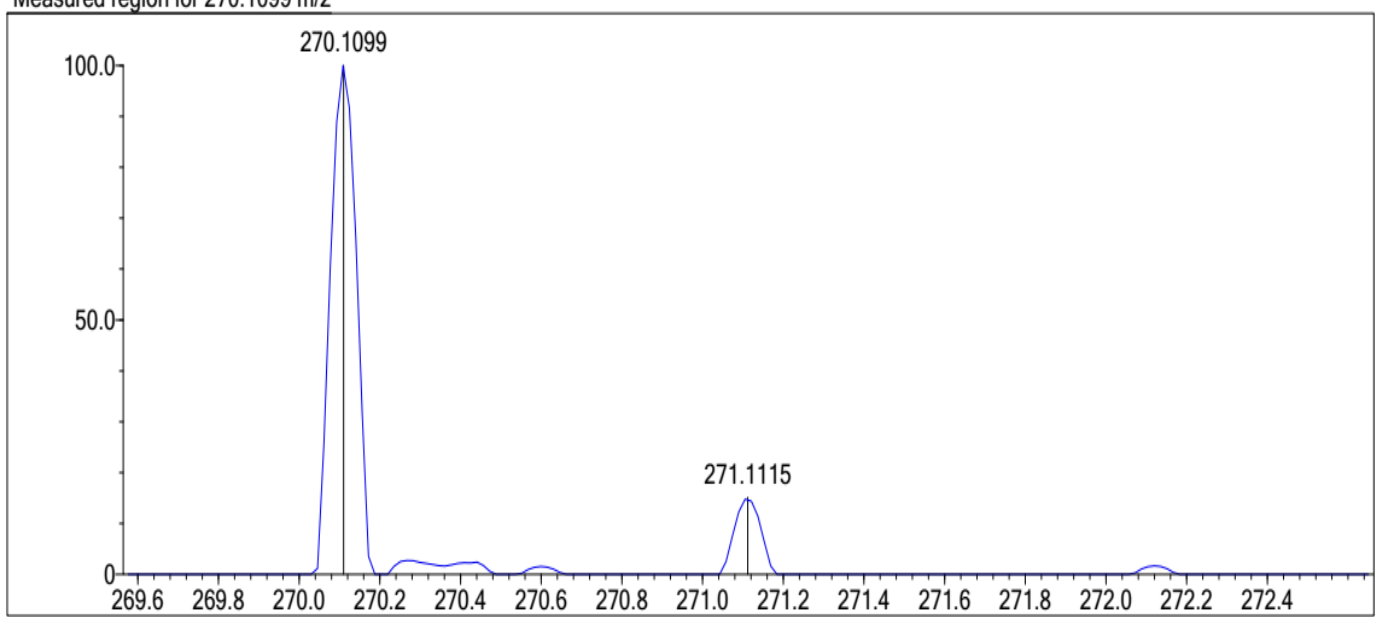

$\mathrm{C} 14 \mathrm{H} 17 \mathrm{~N} 03[\mathrm{M}+\mathrm{Na}]+$ : Predicted region for $270.1101 \mathrm{~m} / \mathrm{z}$

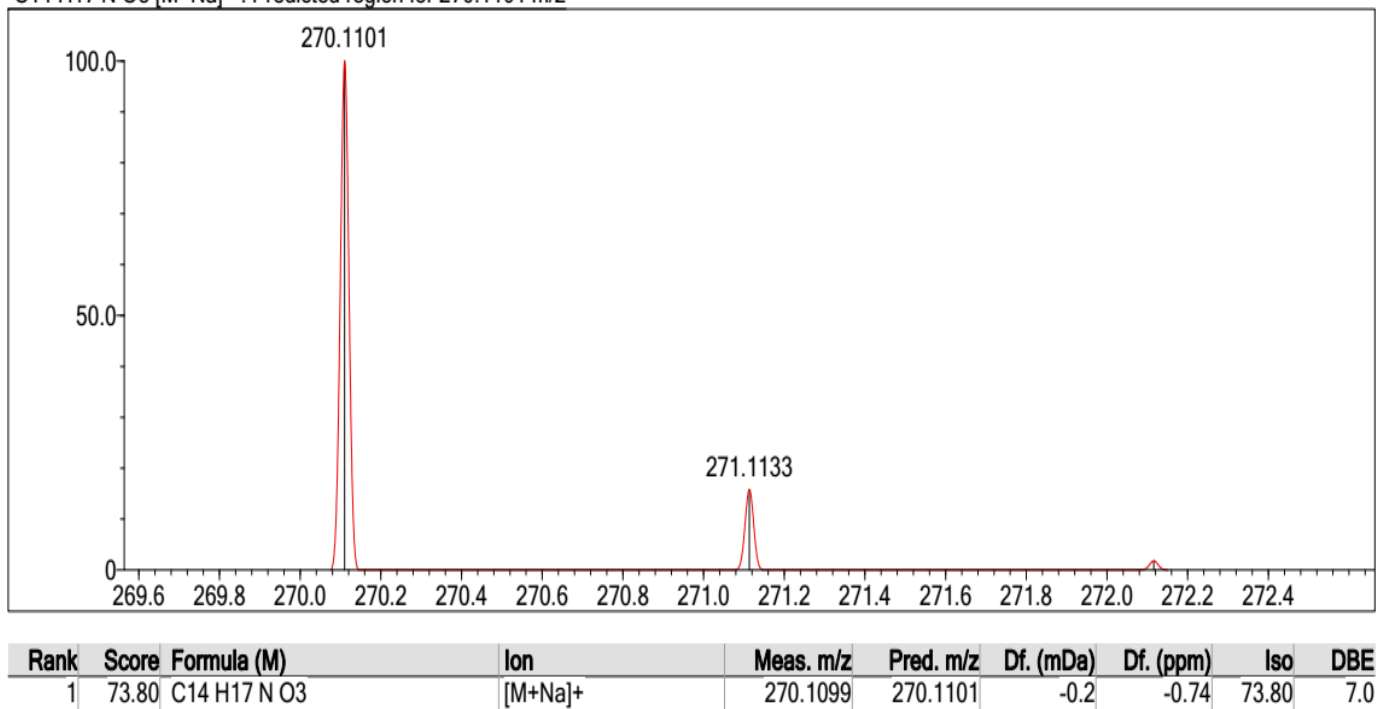

Figure S54. HR-ESIMS spectrum of ( \pm )-alternatine A (7) 
<smiles>C[C@H](O)[C@H](C)OC(=O)Cc1c[nH]c2ccccc12</smiles>

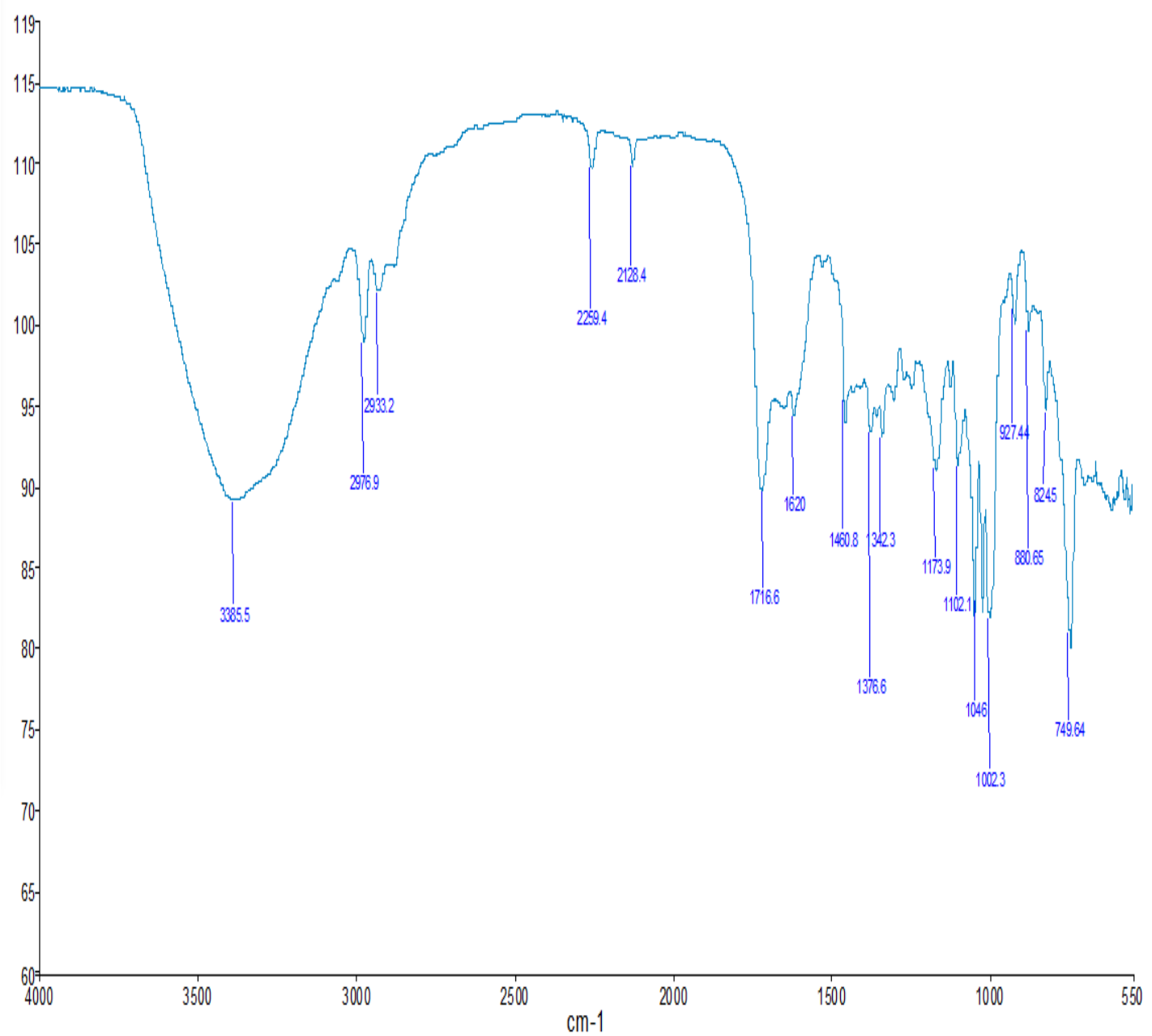

Figure S55. The IR spectrum of ( \pm )-alternatine A (7) 
<smiles>C[C@H](O)[C@H](C)OC(=O)Cc1c[nH]c2ccccc12</smiles>

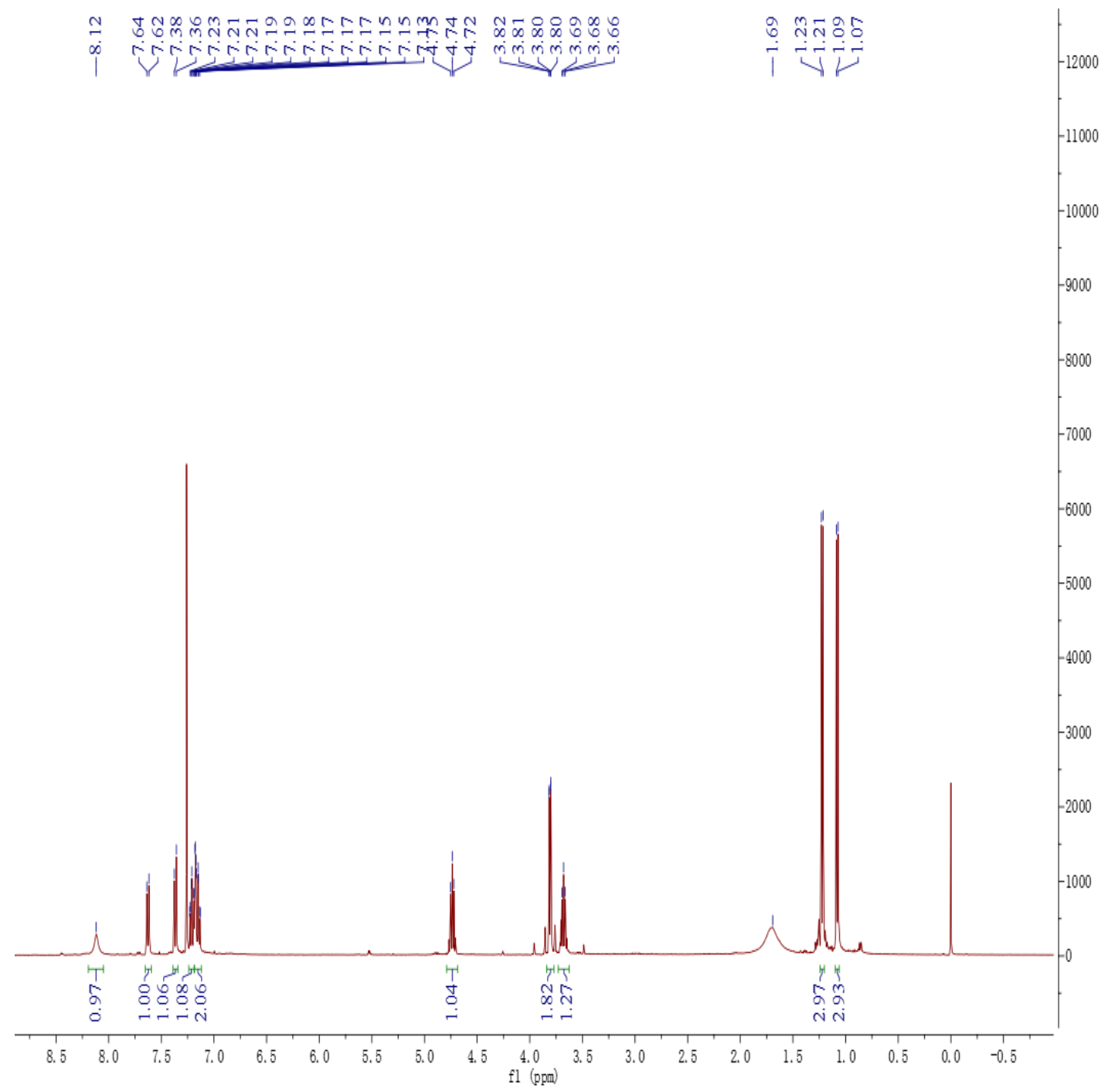

Figure S56. ${ }^{1} \mathrm{H}$ NMR spectrum of $( \pm)$-alternatine A (7) in $\mathrm{CDCl}_{3}(400 \mathrm{MHz})$ 
<smiles>C[C@H](O)[C@H](C)OC(=O)Cc1c[nH]c2ccccc12</smiles>

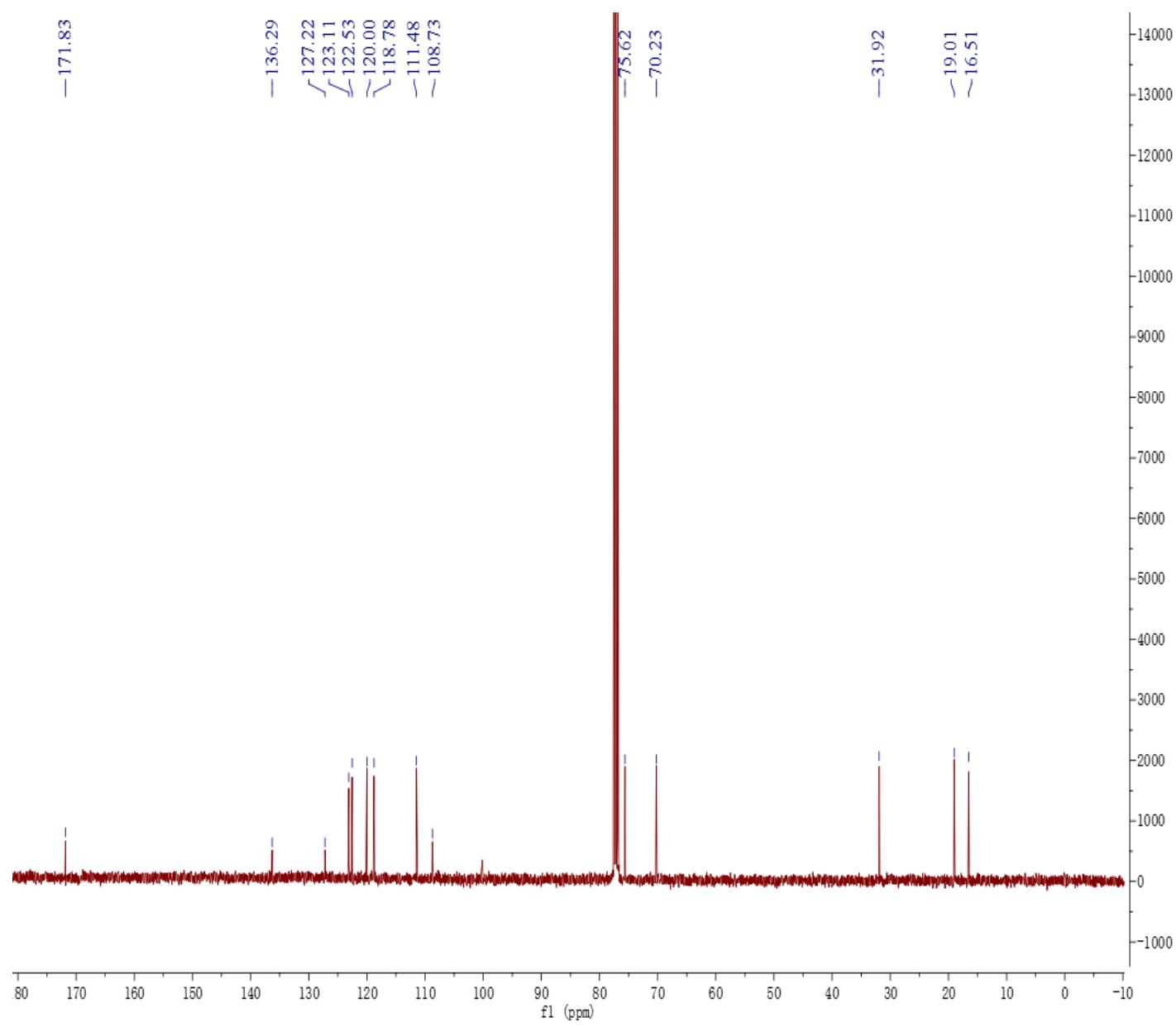

Figure S57. ${ }^{13} \mathrm{C}$ NMR spectrum of $( \pm)$-alternatine $\mathrm{A}(7)$ in $\mathrm{CDCl}_{3}(100 \mathrm{MHz})$ 


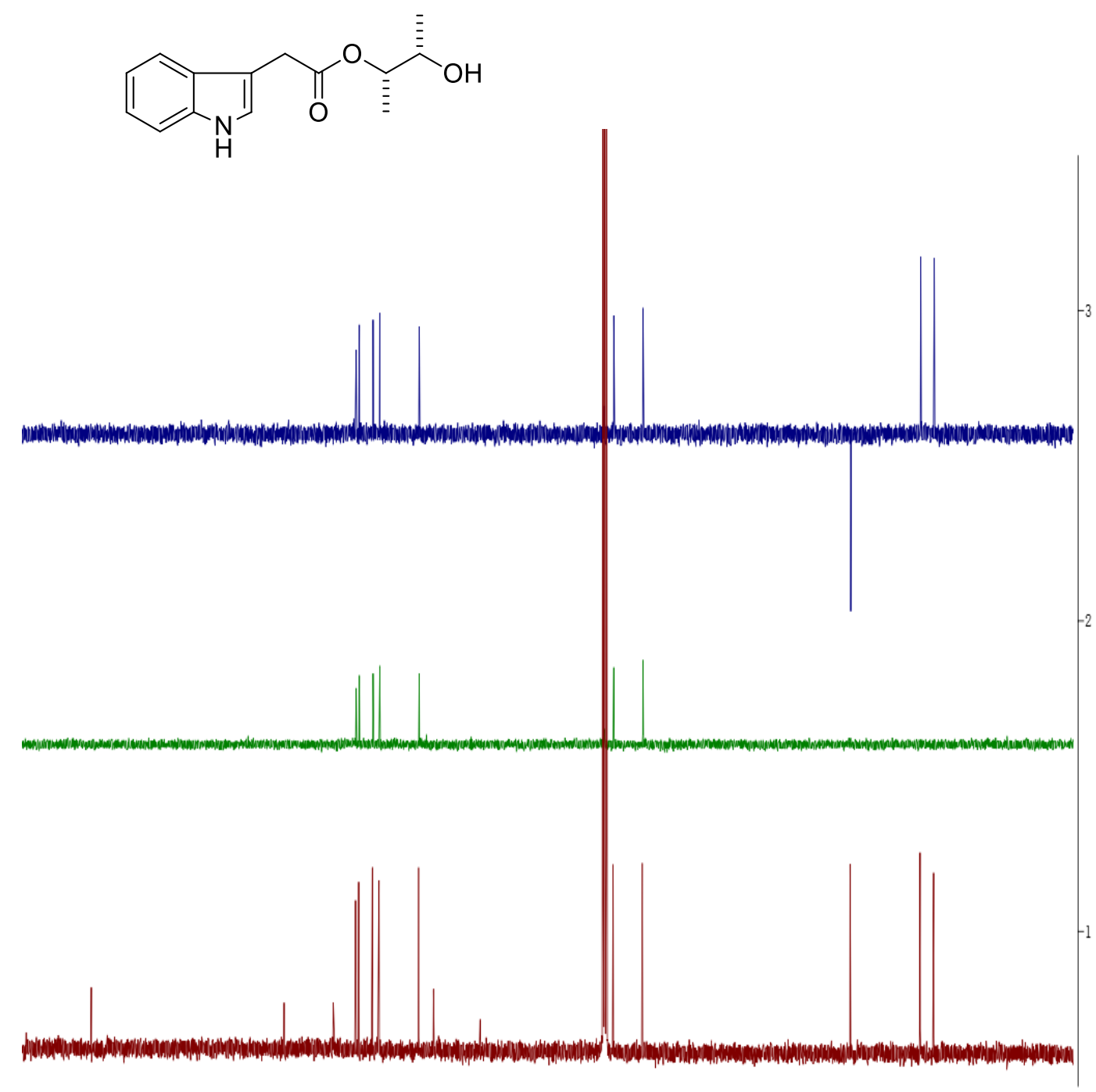

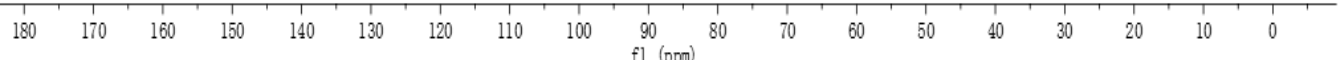

Figure S58. DEPT 90 and DEPT 135 spectra of ( \pm )-alternatine A (7) in $\mathrm{CDCl}_{3}$ 
<smiles>C[C@H](O)[C@H](C)OC(=O)Cc1c[nH]c2ccccc12</smiles>

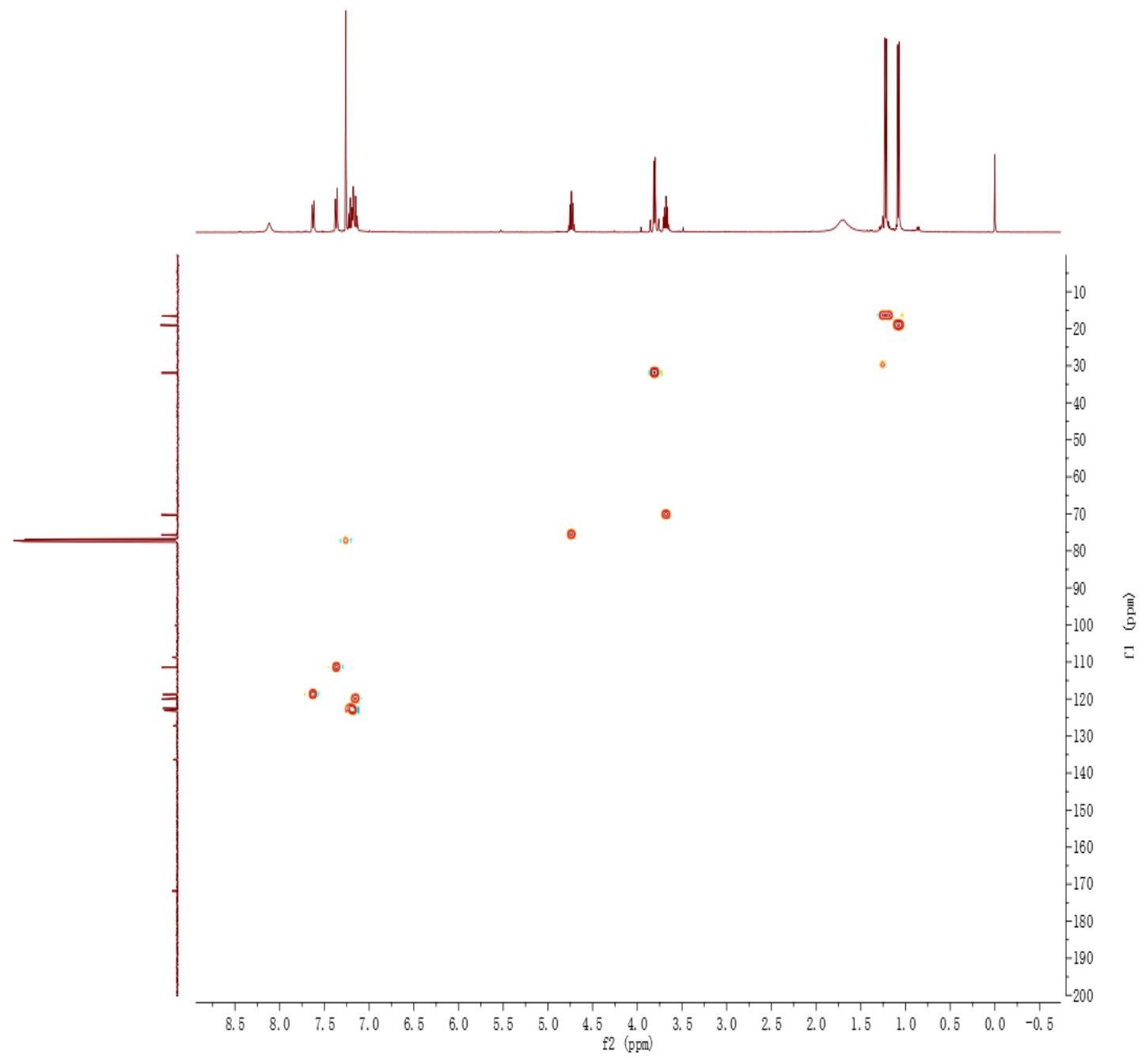

Figure S59. HMQC spectrum of $( \pm)$-alternatine $\mathrm{A}(7)$ in $\mathrm{CDCl}_{3}$ 
<smiles>C[C@H](O)[C@H](C)OC(=O)Cc1c[nH]c2ccccc12</smiles>

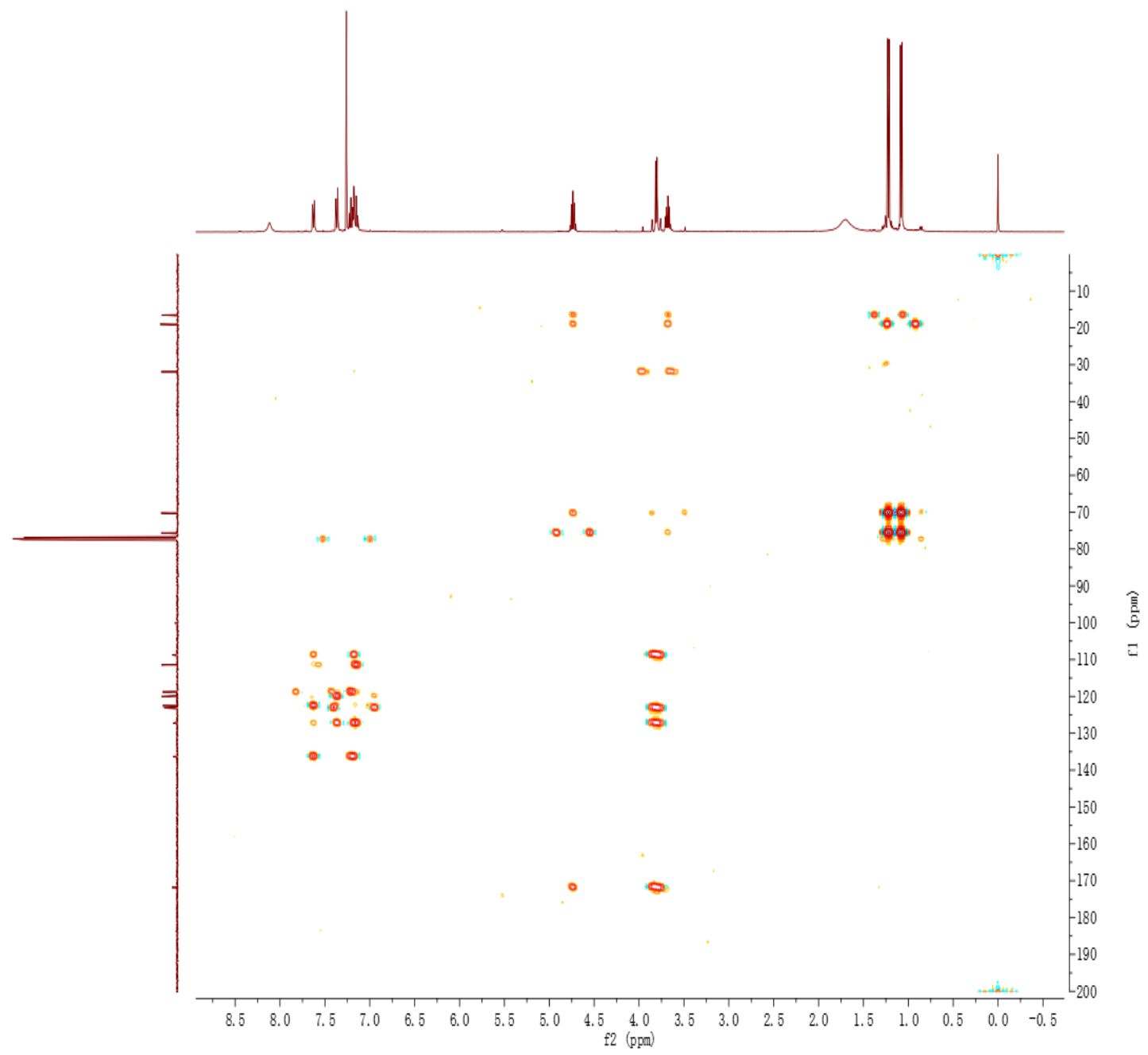

Figure S60. $\mathrm{HMBC}$ spectrum of $( \pm)$-alternatine $\mathrm{A}(\mathbf{7})$ in $\mathrm{CDCl}_{3}$ 
<smiles>C[C@H](O)[C@H](C)OC(=O)Cc1c[nH]c2ccccc12</smiles>

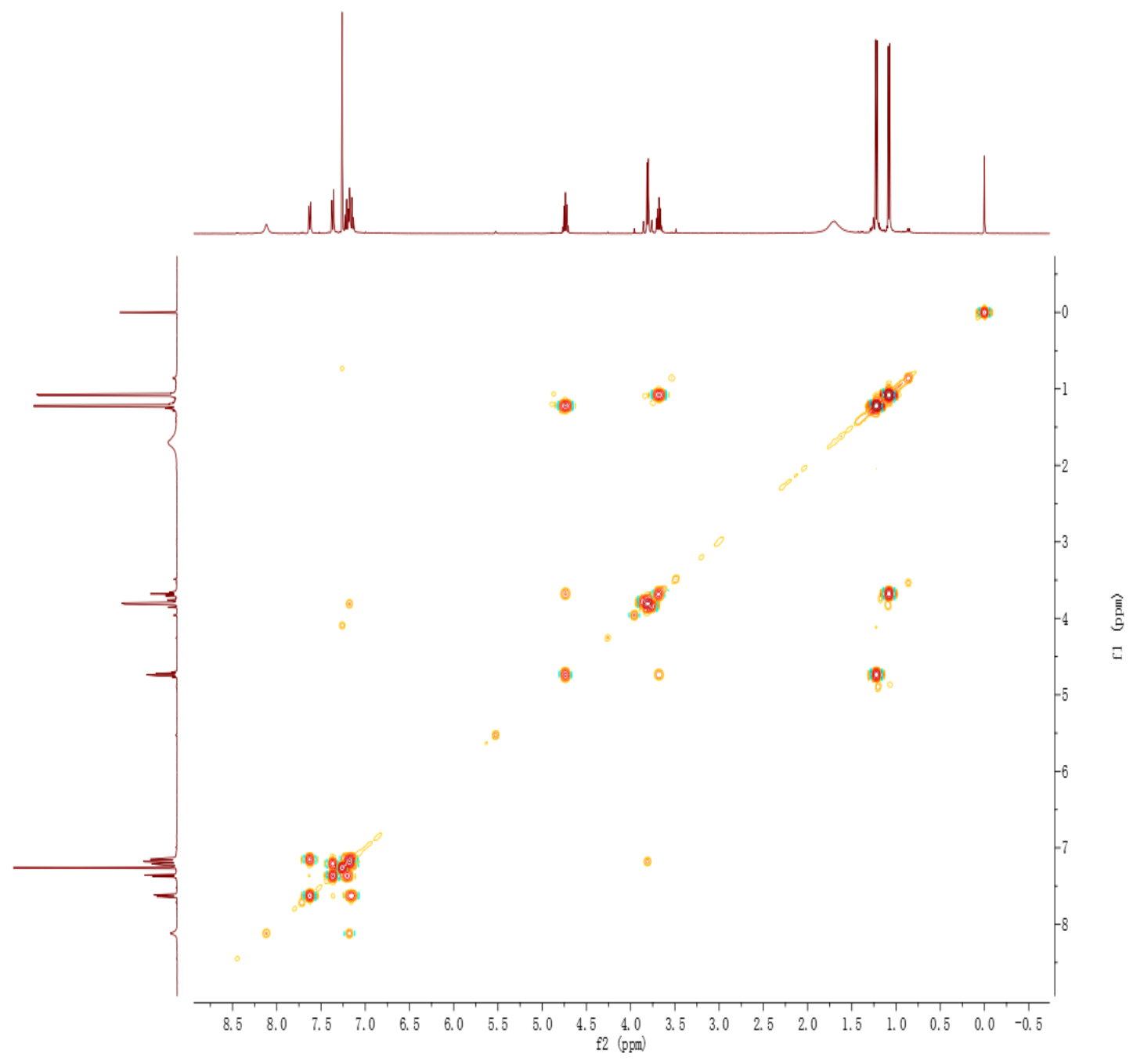

Figure S61. COSY spectrum of ( \pm -)-alternatine A (7) in $\mathrm{CDCl}_{3}$ 
<smiles>C[C@H](O)[C@H](C)OC(=O)Cc1c[nH]c2ccccc12</smiles>

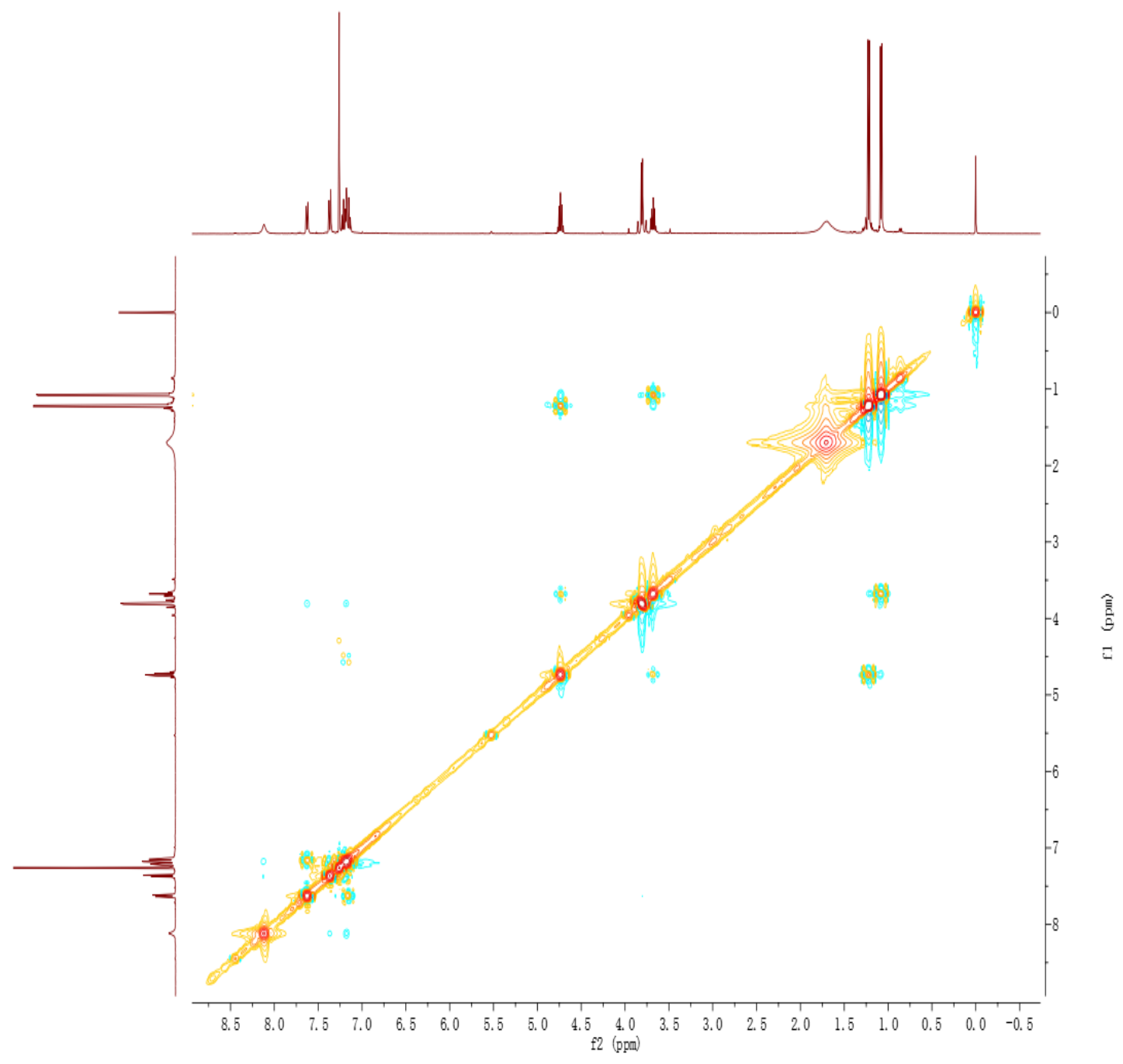

Figure S62. NOESY spectrum of ( \pm )-alternatine A (7) in $\mathrm{CDCl}_{3}$ 


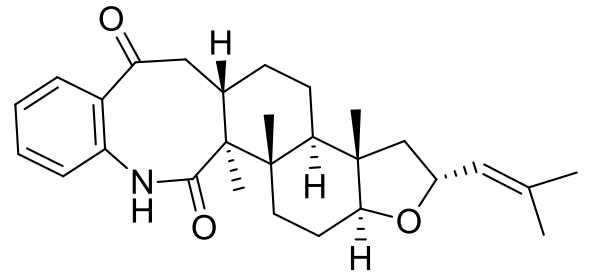

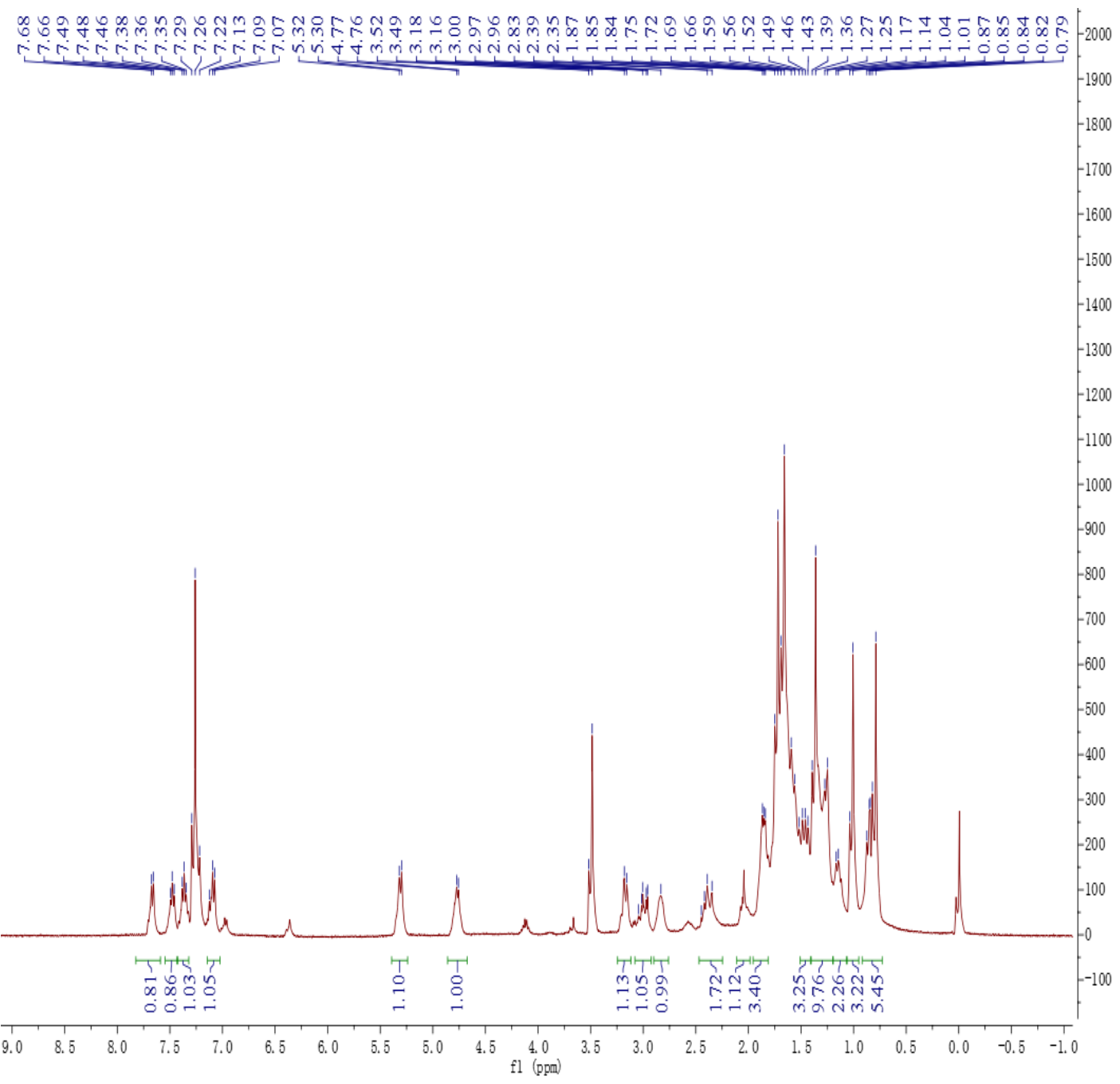

Figure $\mathrm{S} 65 .{ }^{1} \mathrm{H}$ NMR spectrum of 8 in $\mathrm{CDCl}_{3}(400 \mathrm{MHz})$ 


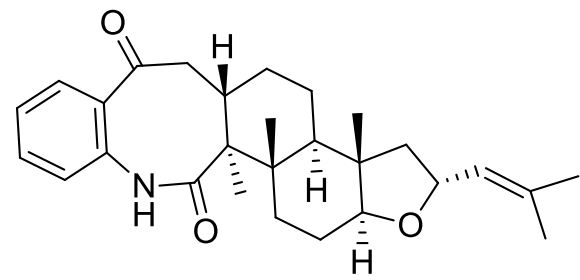

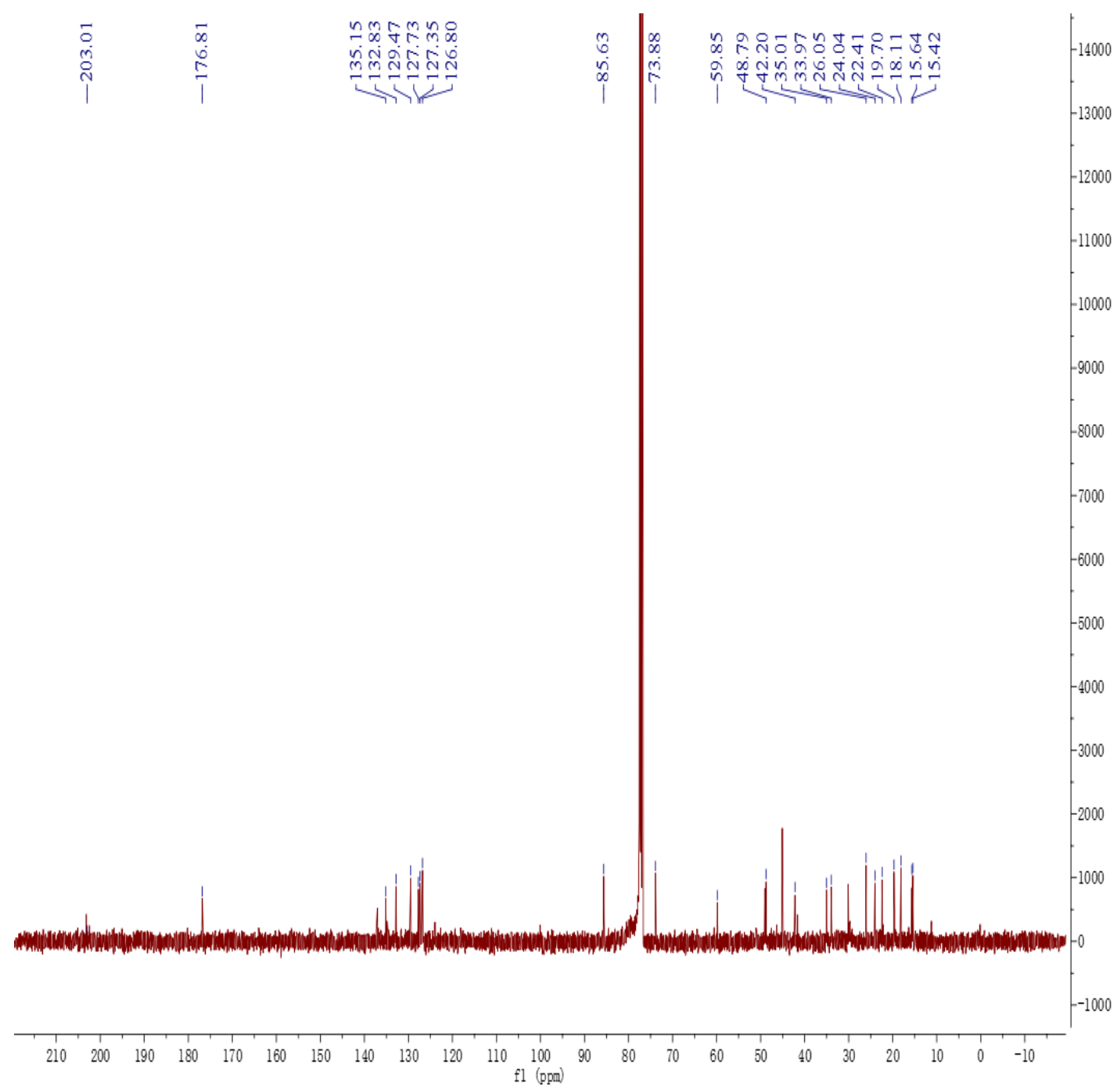

Figure S66. ${ }^{13} \mathrm{C}$ NMR spectrum of 8 in $\mathrm{CDCl}_{3}(100 \mathrm{MHz})$ 


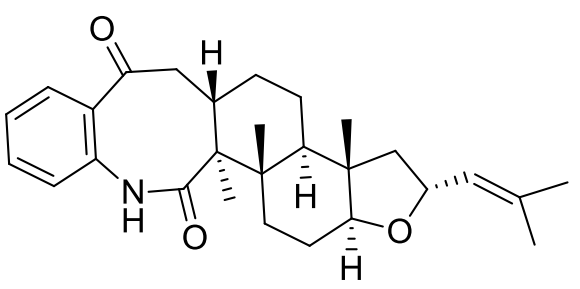

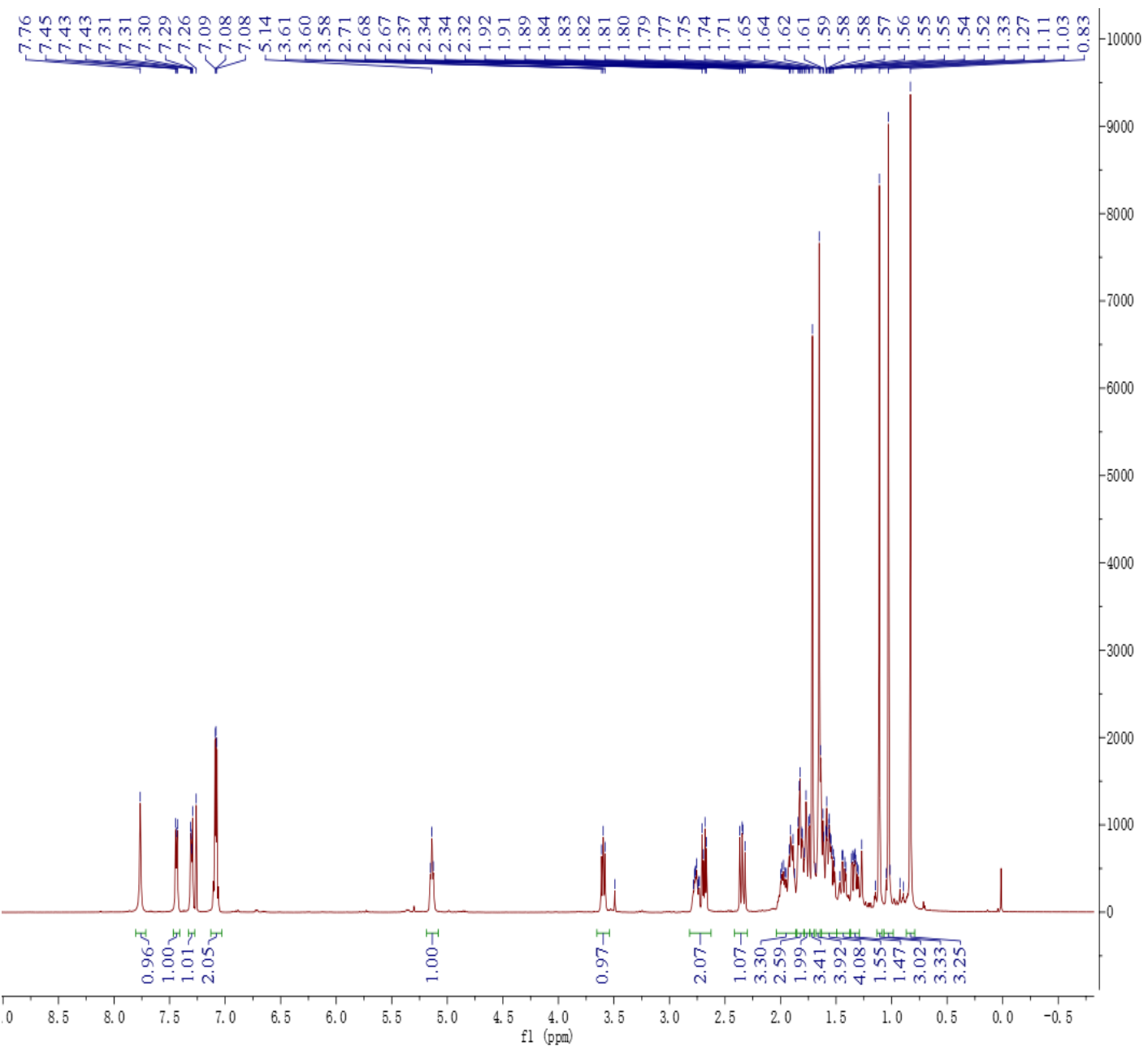

Figure S67. ${ }^{1} \mathrm{H}$ NMR spectrum of 9 in $\mathrm{CDCl}_{3}(400 \mathrm{MHz})$ 


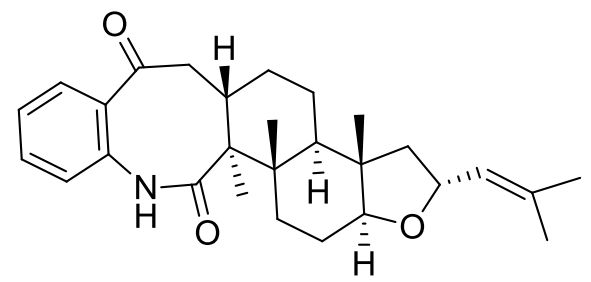

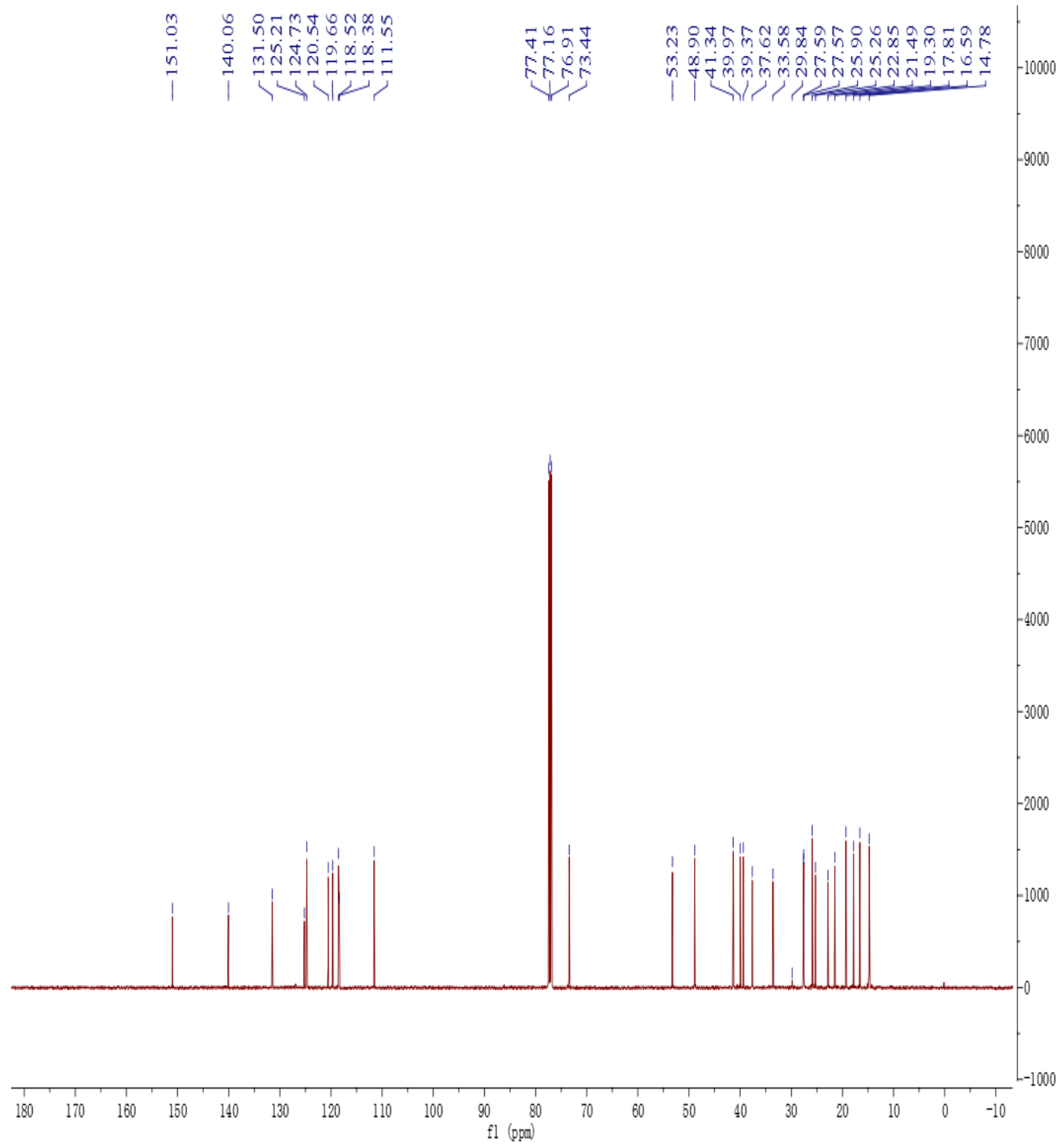

Figure $\mathrm{S} 68 .{ }^{13} \mathrm{C}$ NMR spectrum of 9 in $\mathrm{CDCl}_{3}(100 \mathrm{MHz})$ 


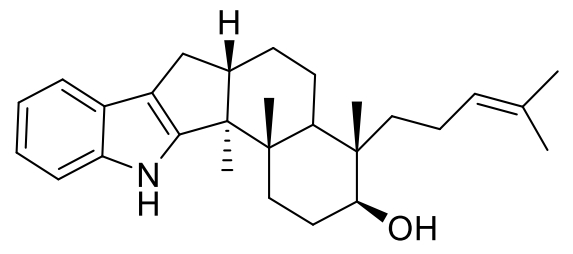

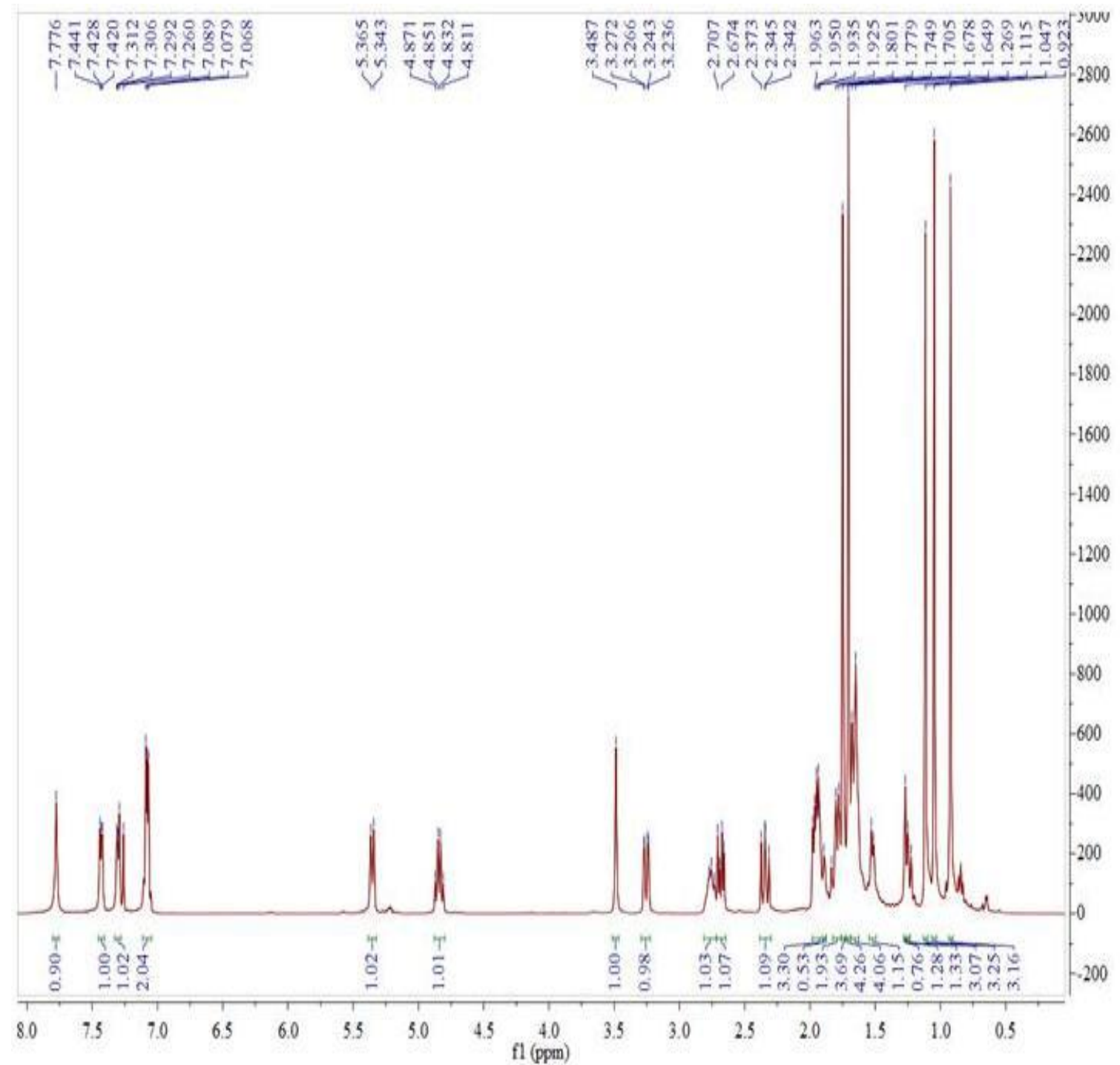

Figure S69. ${ }^{1} \mathrm{H}$ NMR spectrum of $\mathbf{1 0}$ in $\mathrm{CDCl}_{3}(400 \mathrm{MHz})$ 
<smiles>CC(C)=CCC[C@]1(C)[C@@H](O)CC[C@]2(C)c3[nH]c4ccccc4c3C[C@H]2CC[C@H]1C</smiles>

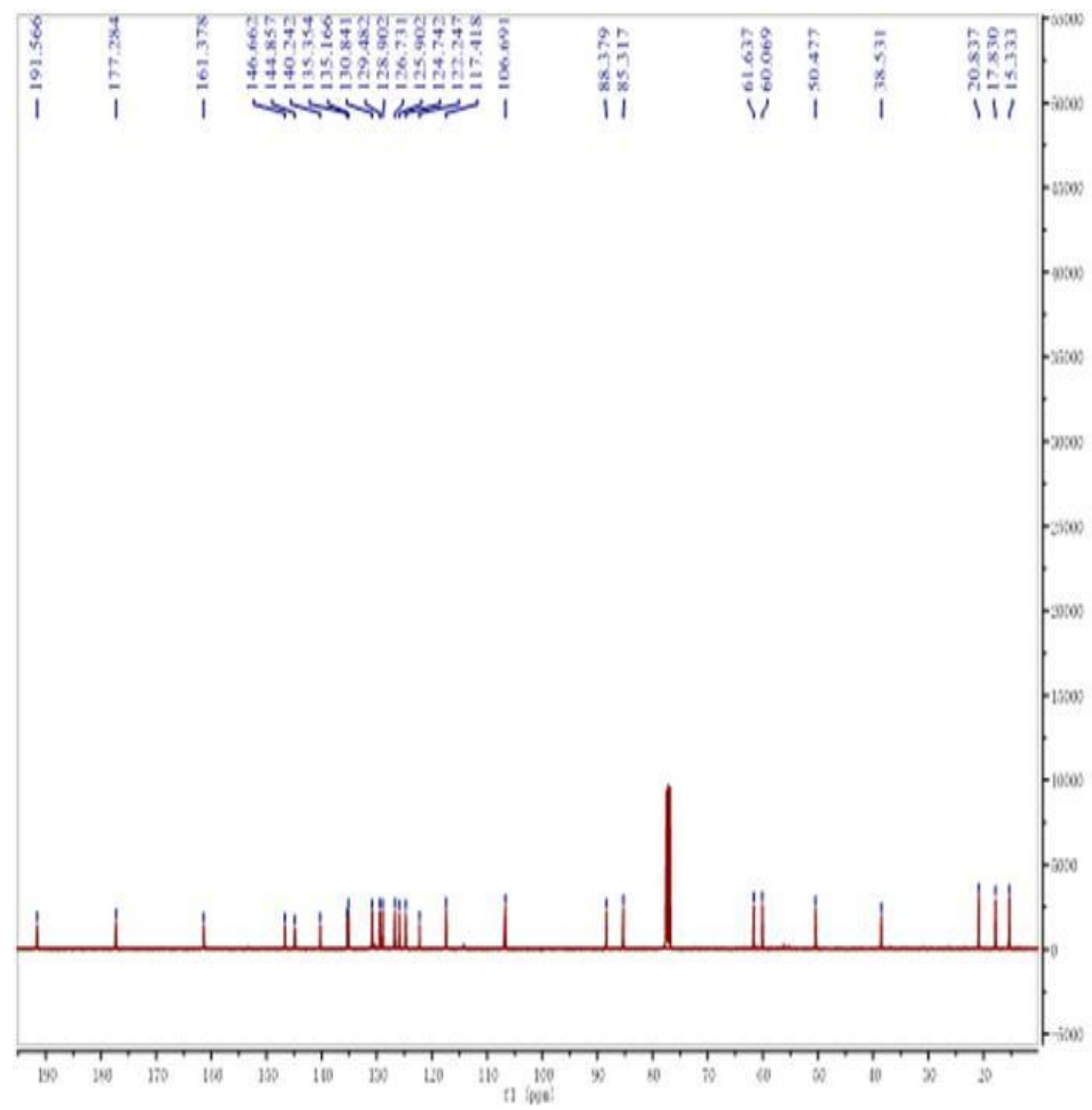

Figure S70. ${ }^{13} \mathrm{C}$ NMR spectrum of $\mathbf{1 0}$ in $\mathrm{CDCl}_{3}(100 \mathrm{MHz})$ 
<smiles>O=C1Nc2ccccc2C1(c1c[nH]c2ccccc12)c1c[nH]c2ccccc12</smiles>

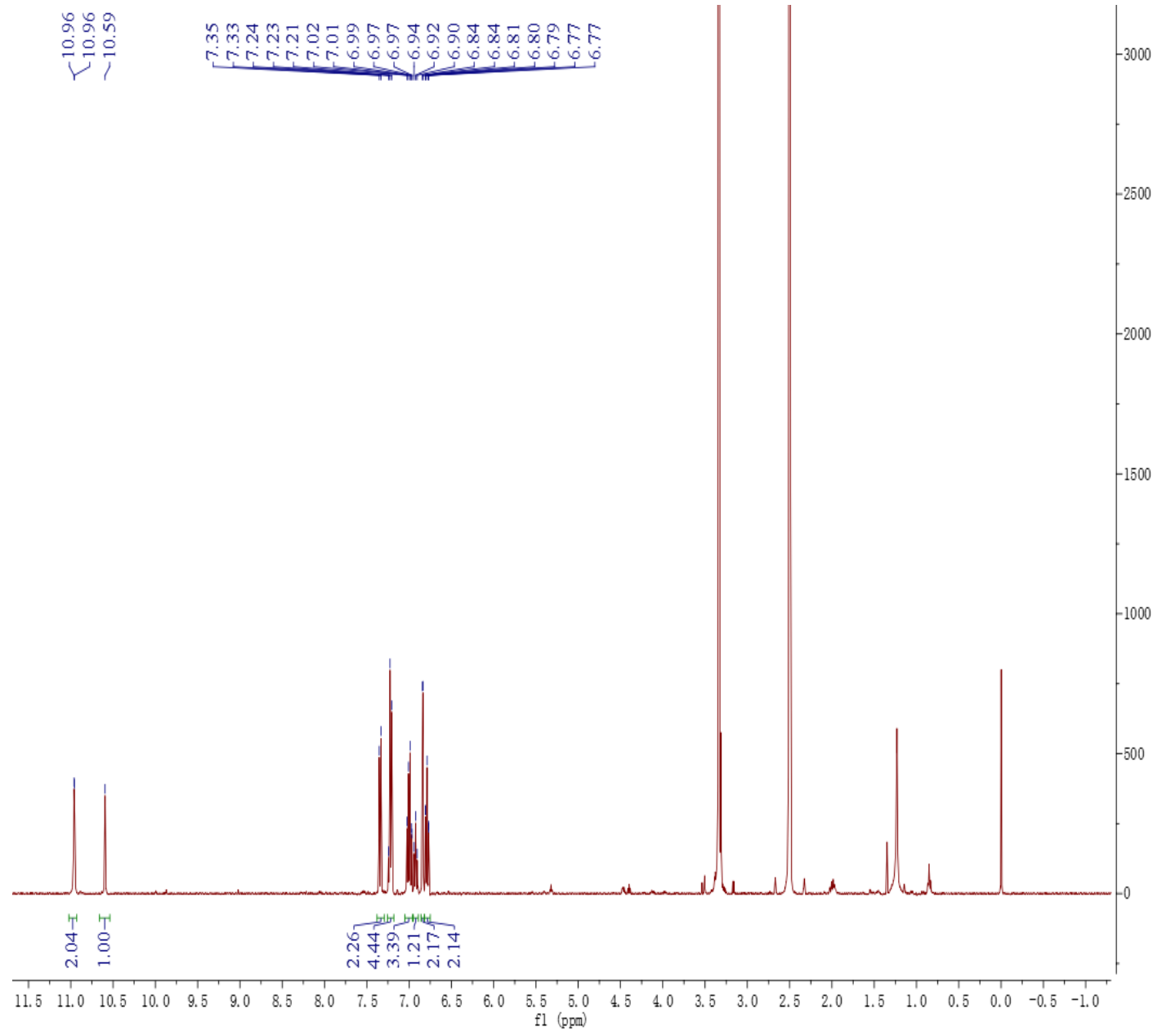

Figure S71. ${ }^{1} \mathrm{H}$ NMR spectrum of $\mathbf{1 1}$ in DMSO- $d_{6}(400 \mathrm{MHz})$ 
<smiles>O=C1Nc2ccccc2C1(c1c[nH]c2ccccc12)c1c[nH]c2ccccc12</smiles>

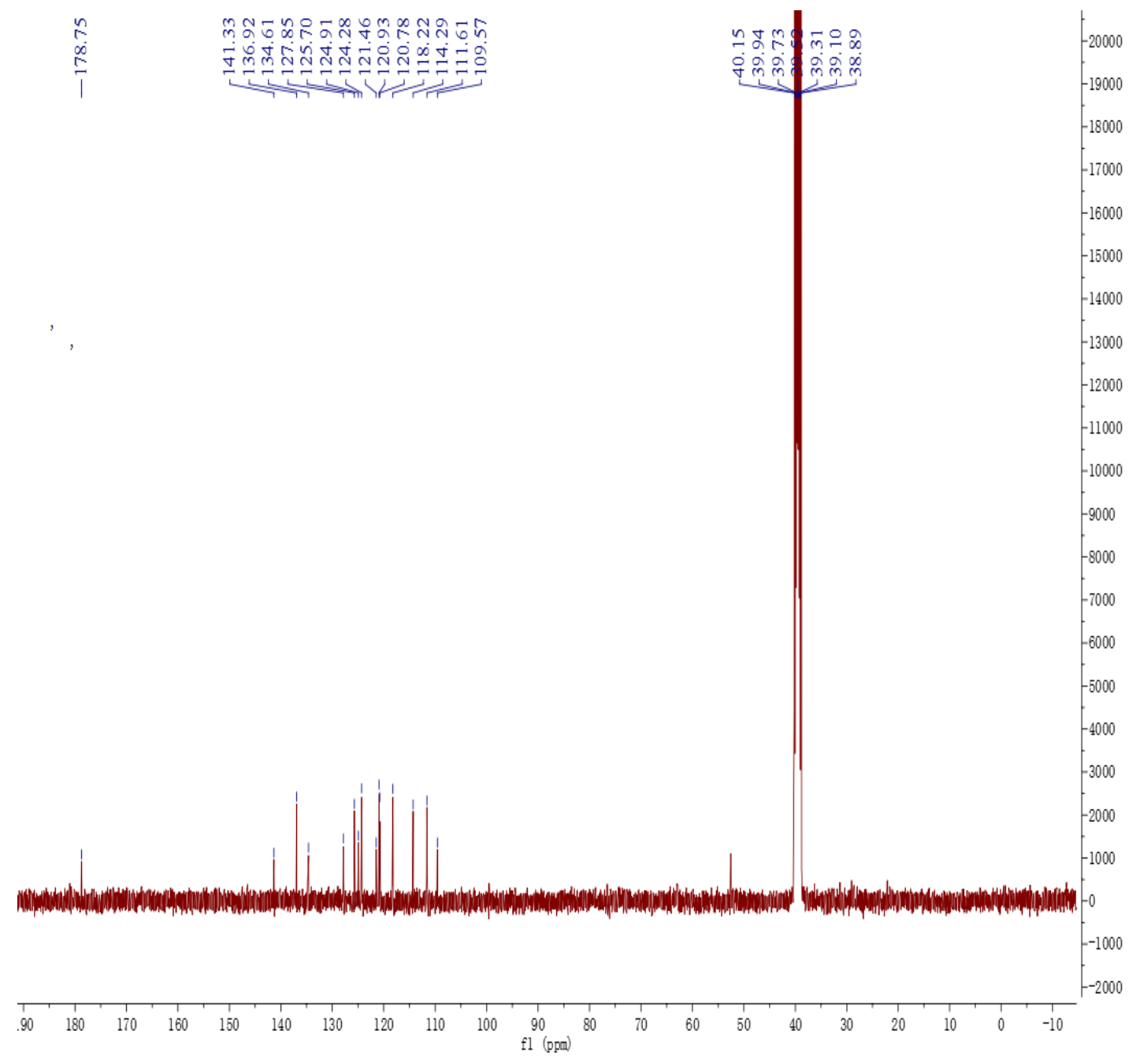

Figure S72. ${ }^{13} \mathrm{C}$ NMR spectrum of $\mathbf{1 1}$ in DMSO- $d_{6}(100 \mathrm{MHz})$ 
<smiles>CC(=O)C(C)(c1c[nH]c2ccccc12)c1c[nH]c2ccccc12</smiles>

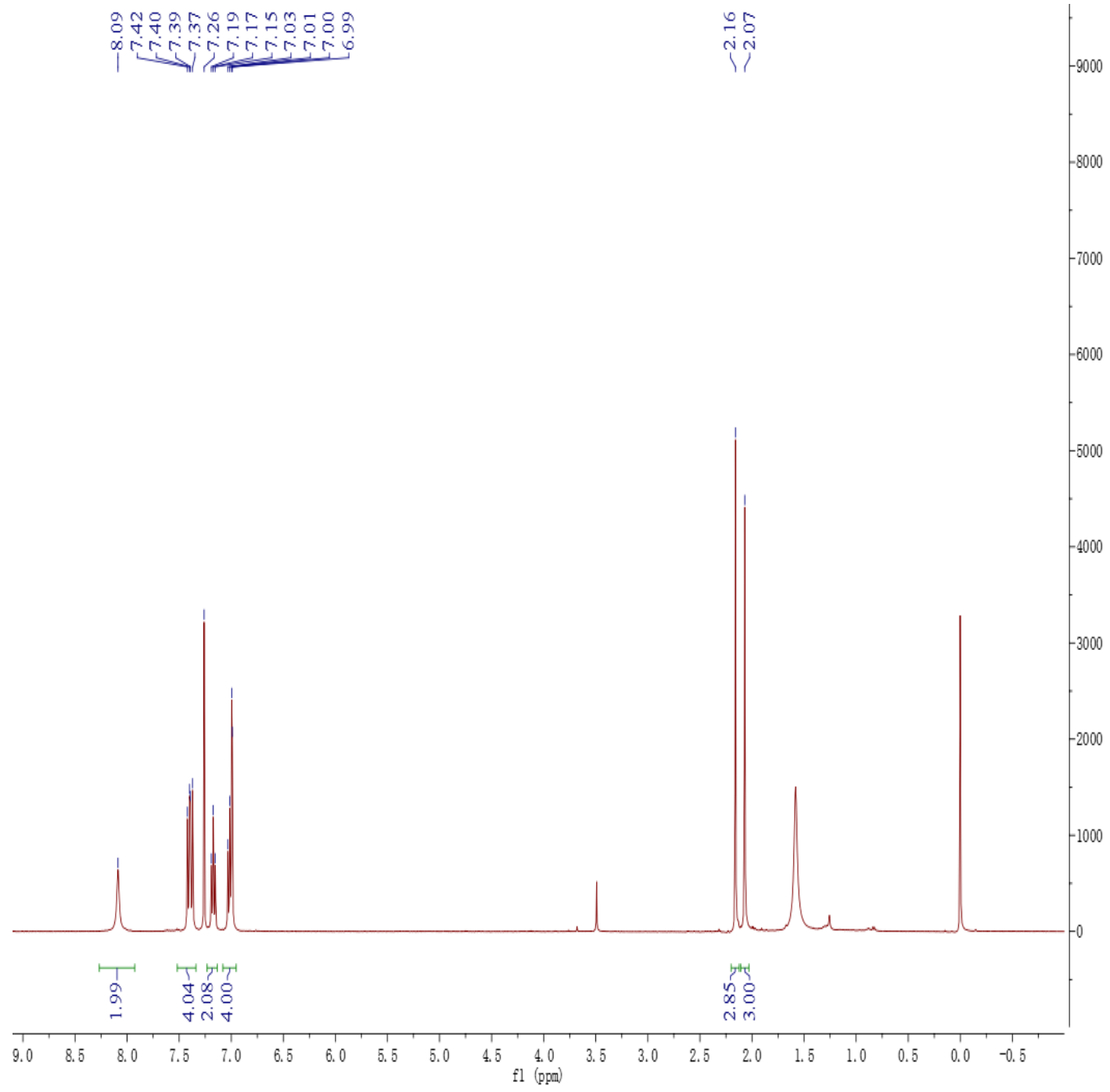

Figure S73. ${ }^{1} \mathrm{H}$ NMR spectrum of $\mathbf{1 2}$ in $\mathrm{CDCl}_{3}(400 \mathrm{MHz})$ 
<smiles>CC(=O)C(C)(c1c[nH]c2ccccc12)c1c[nH]c2ccccc12</smiles>

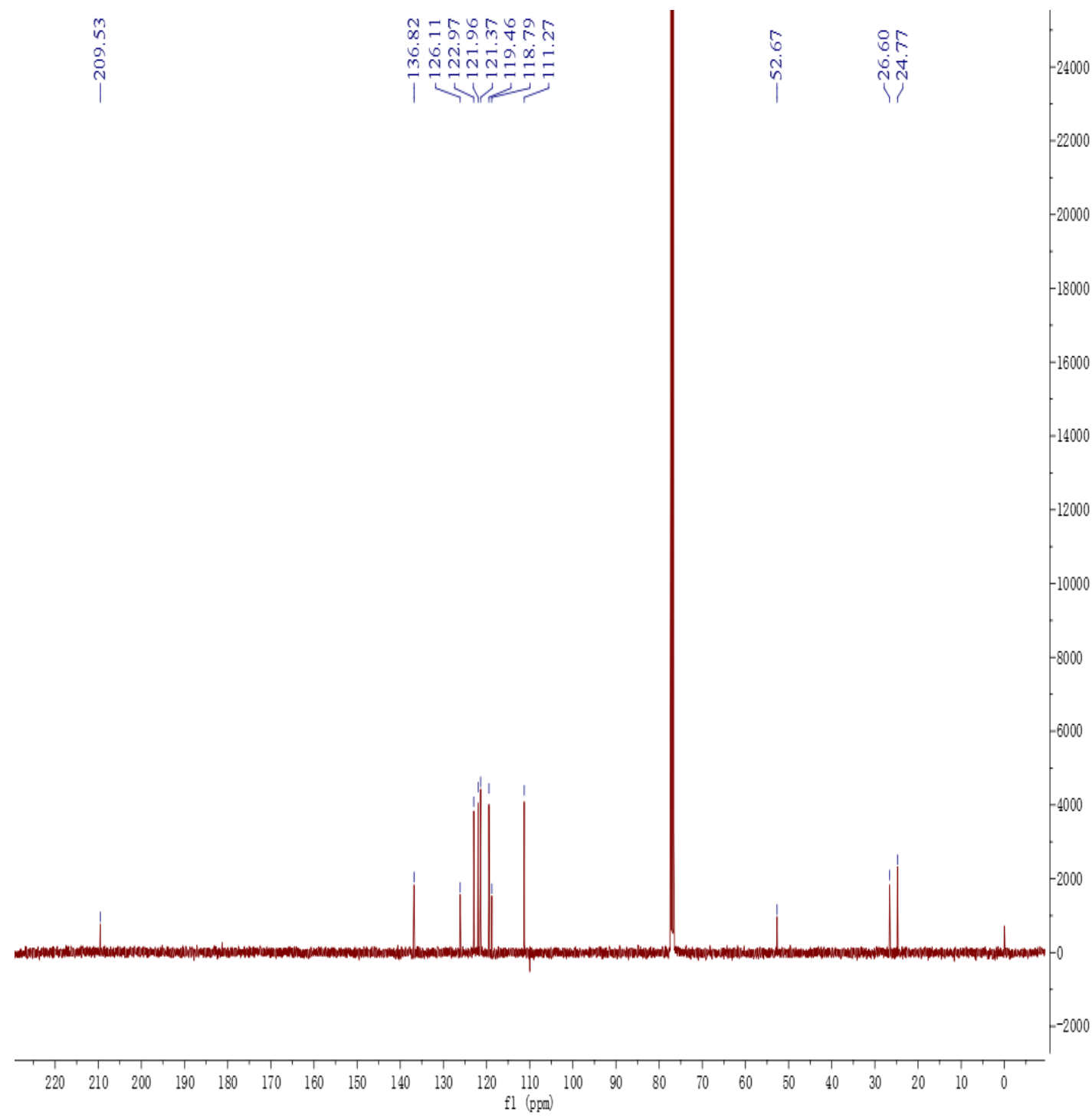

Figure $\mathrm{S} 74 .{ }^{13} \mathrm{C}$ NMR spectrum of $\mathbf{1 2}$ in $\mathrm{CDCl}_{3}(100 \mathrm{MHz})$ 
<smiles>CS(=O)CCC(c1c[nH]c2ccccc12)c1c[nH]c2ccccc12</smiles>

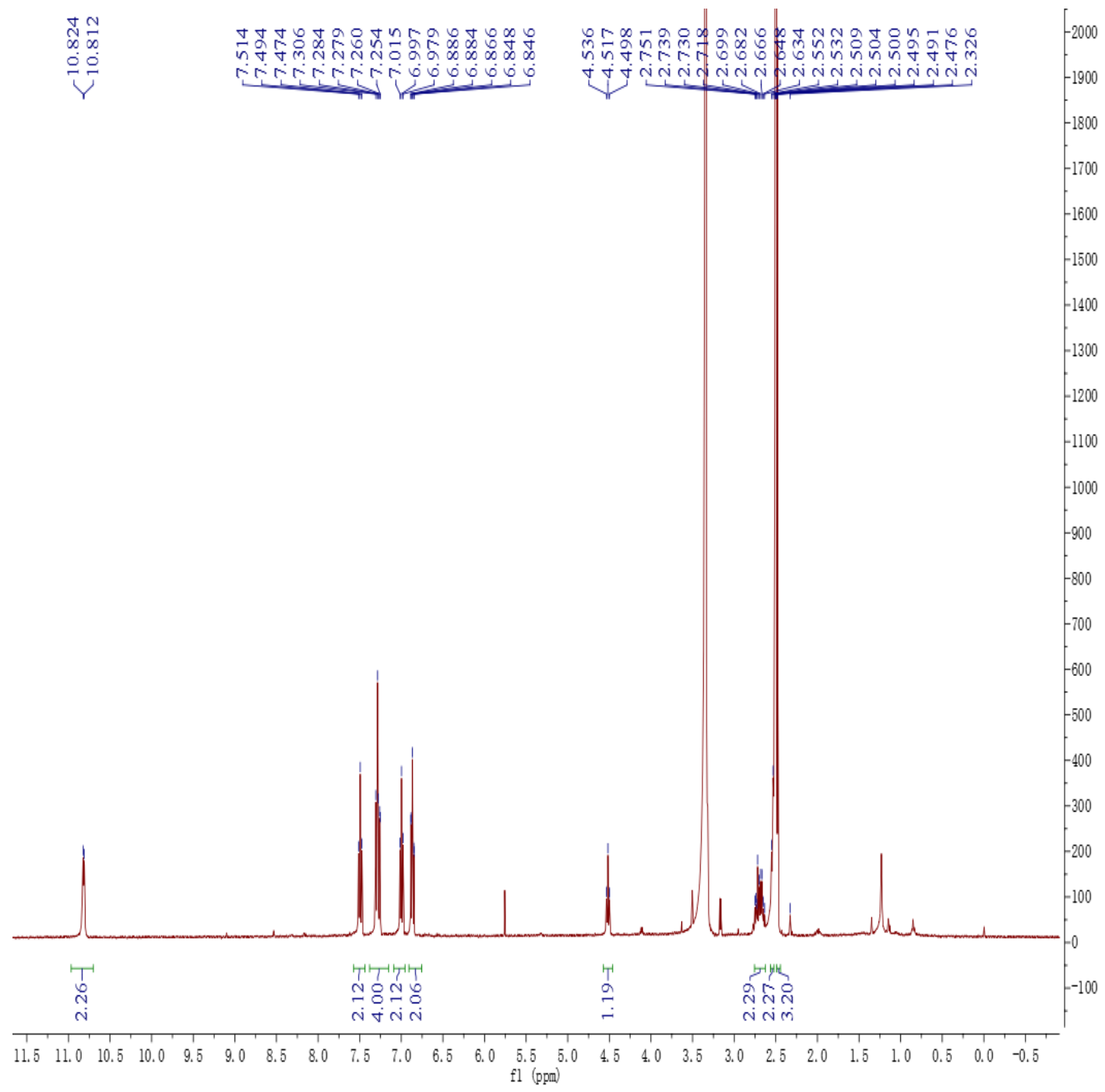

Figure S75. ${ }^{1} \mathrm{H}$ NMR spectrum of $\mathbf{1 3}$ in DMSO- $d_{6}(400 \mathrm{MHz})$ 

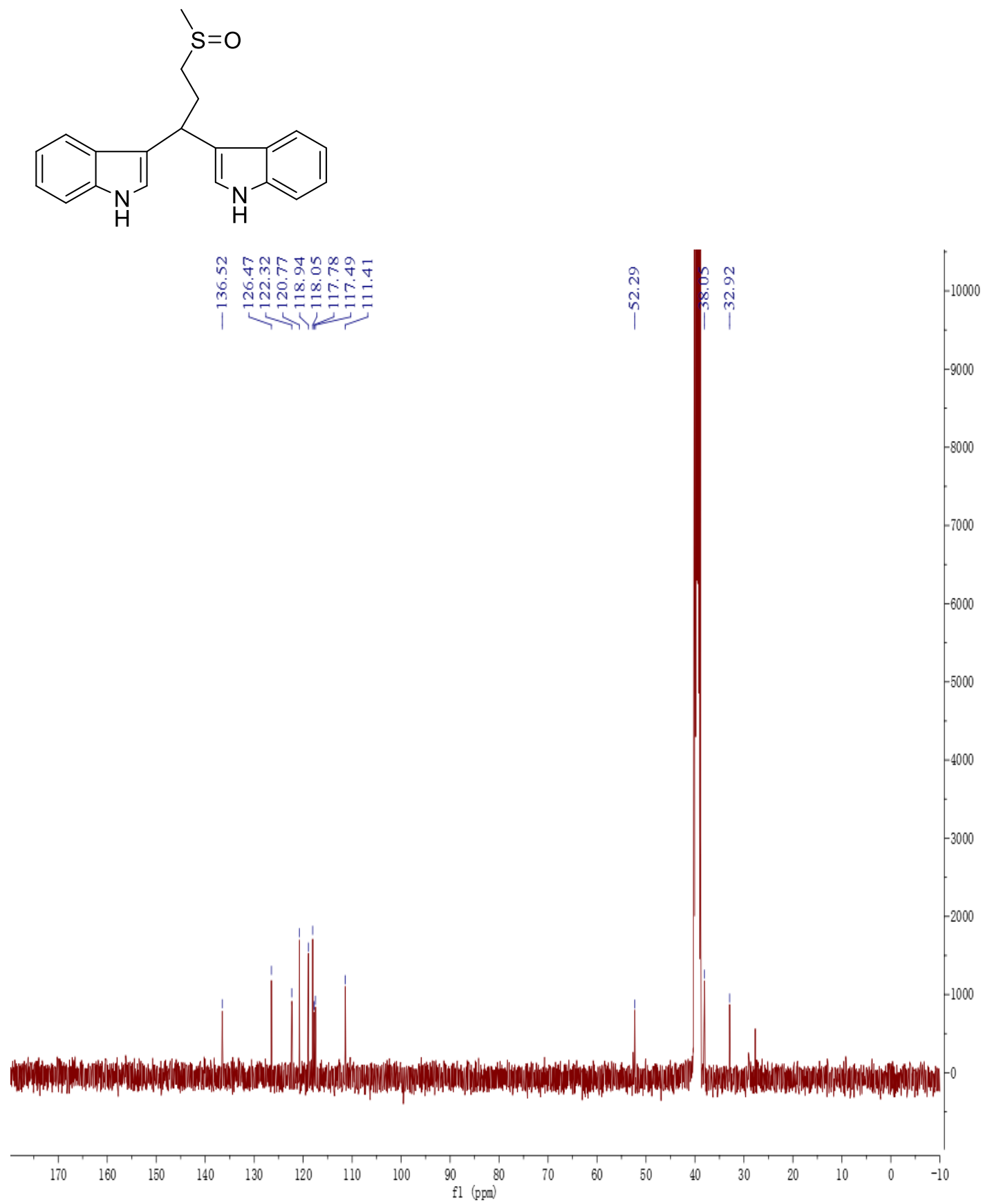

Figure S76. ${ }^{13} \mathrm{C}$ NMR spectrum of $\mathbf{1 3}$ in DMSO- $d_{6}(100 \mathrm{MHz})$ 
<smiles>Nc1ccccc1C(c1c[nH]c2ccccc12)c1c[nH]c2ccccc12</smiles>

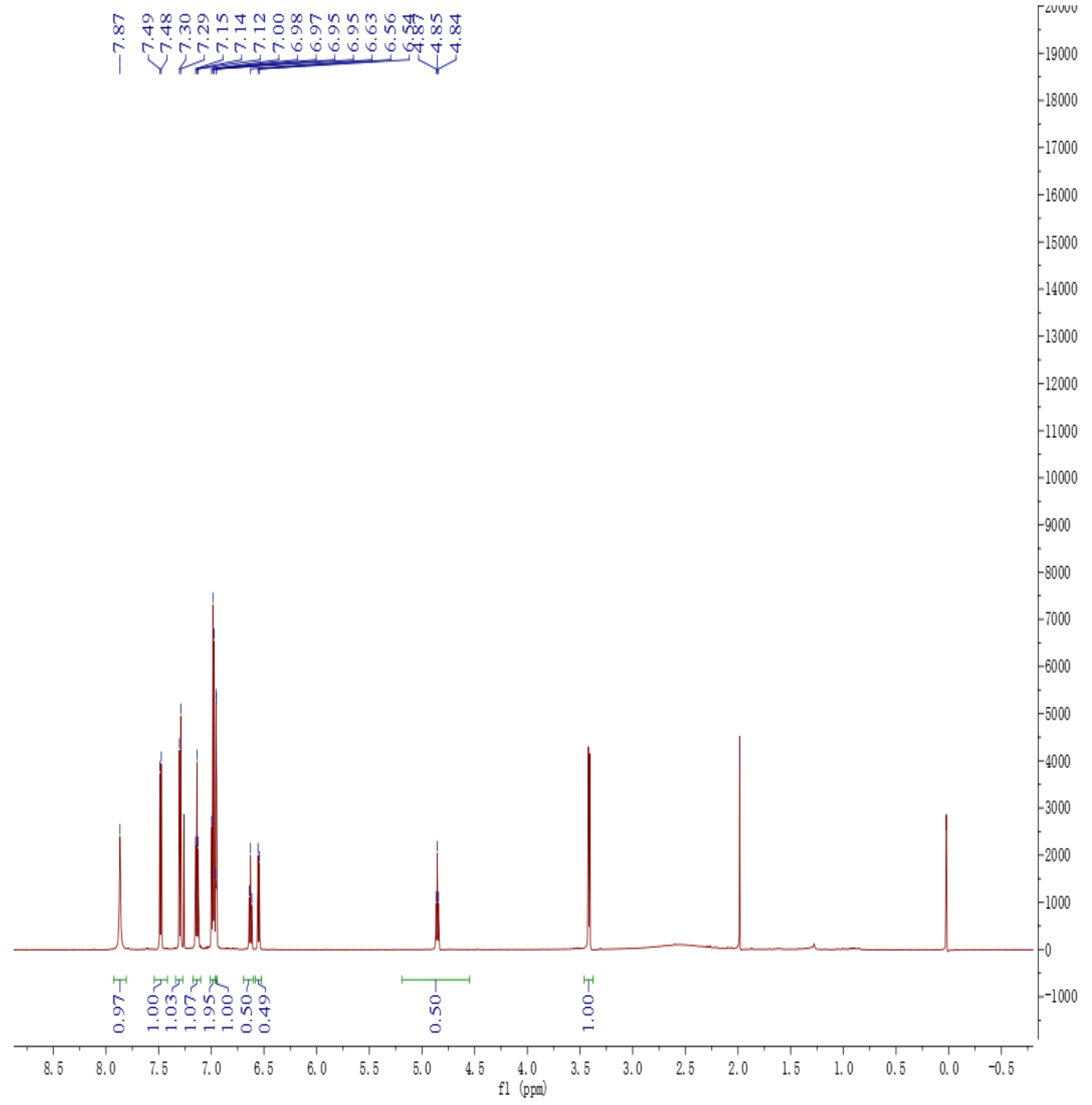

Figure S77. ${ }^{1} \mathrm{H}$ NMR spectrum of 14 in $\mathrm{CDCl}_{3}(400 \mathrm{MHz})$ 
<smiles>Nc1ccccc1C(c1c[nH]c2ccccc12)c1c[nH]c2ccccc12</smiles>

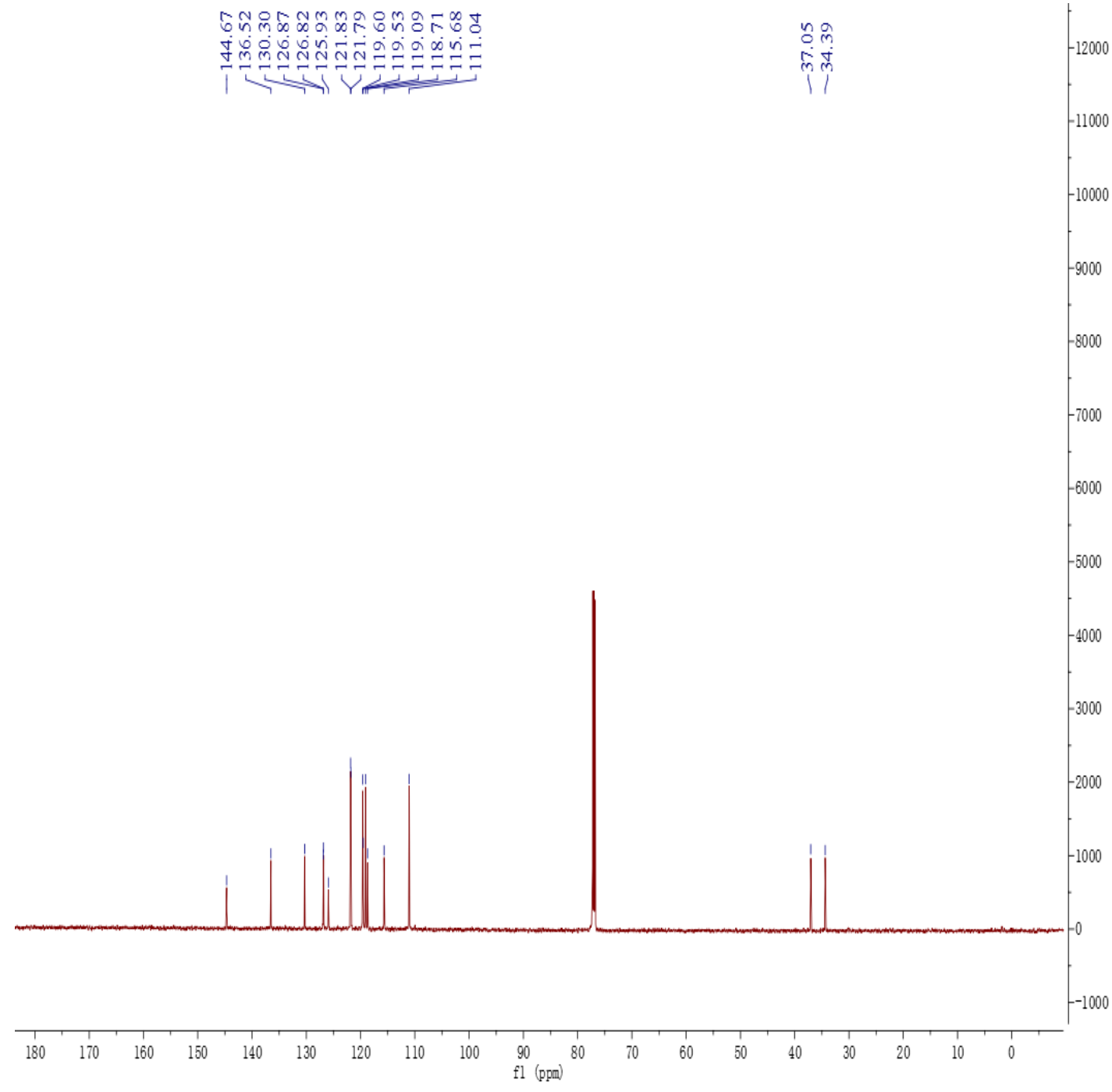

Figure S78. ${ }^{13} \mathrm{C}$ NMR spectrum of $\mathbf{1 4}$ in $\mathrm{CDCl}_{3}(100 \mathrm{MHz})$ 
<smiles>O=C(C(=O)c1c[nH]c2ccccc12)c1c[nH]c2ccccc12</smiles>

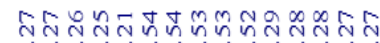

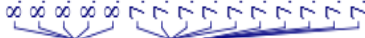

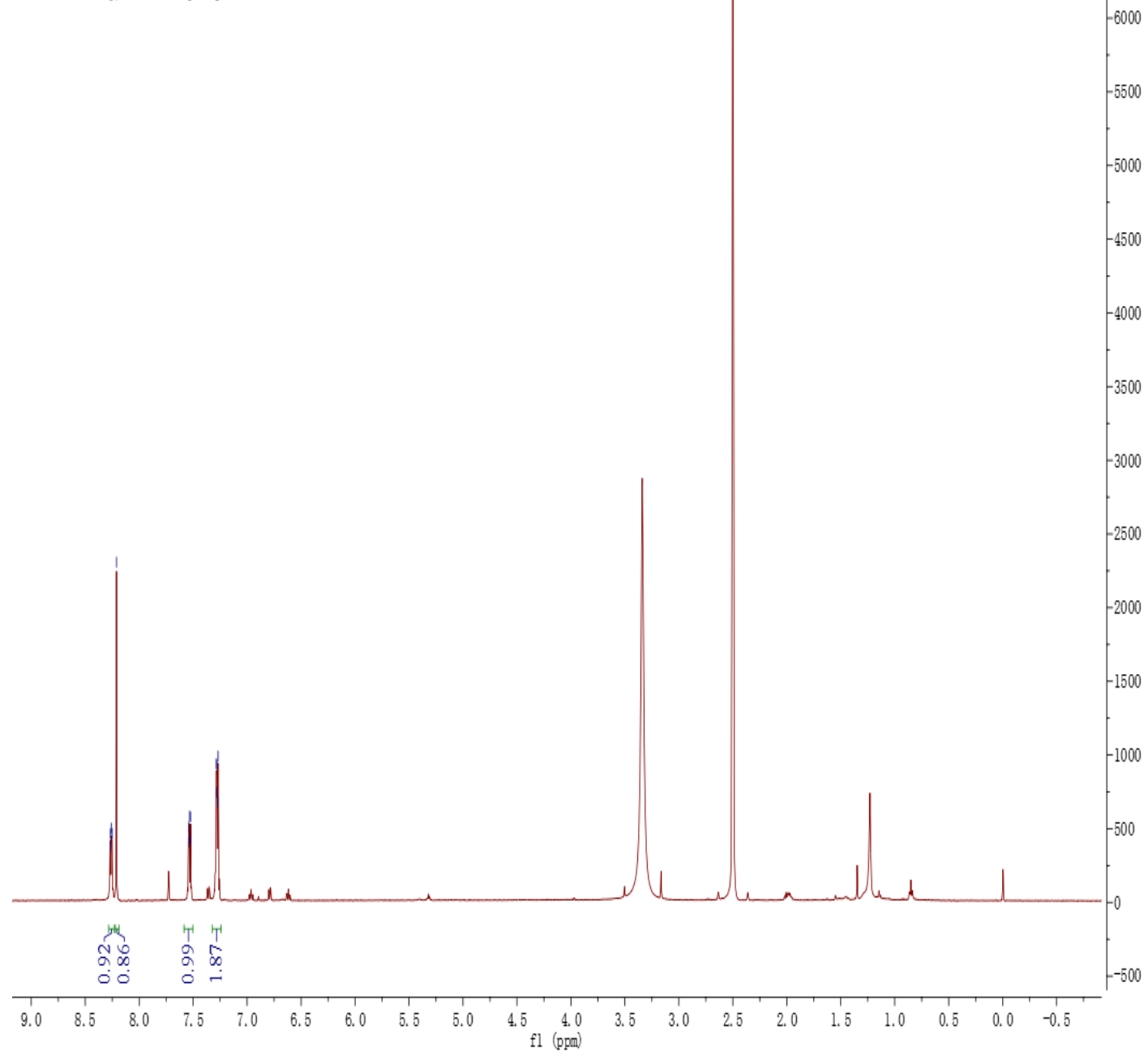

Figure S79. ${ }^{1} \mathrm{H}$ NMR spectrum of 15 in DMSO- $d_{6}(400 \mathrm{MHz})$ 
<smiles>O=C(C(=O)c1c[nH]c2ccccc12)c1c[nH]c2ccccc12</smiles>

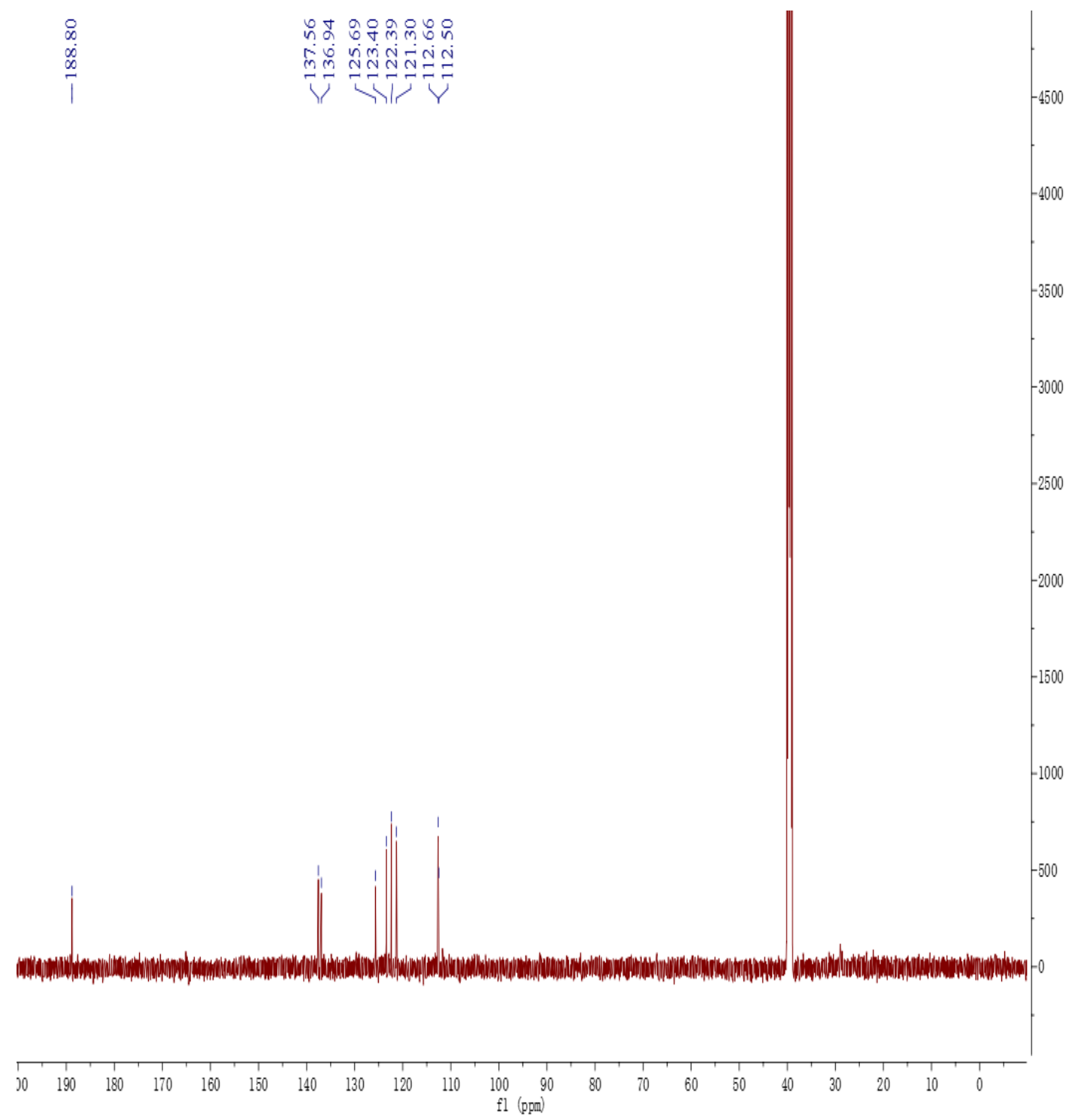

Figure S80. ${ }^{13} \mathrm{C}$ NMR spectrum of $\mathbf{1 5}$ in DMSO- $d_{6}(100 \mathrm{MHz})$ 
<smiles>O=C(c1c[nH]c2ccccc12)c1nccc2c1[nH]c1ccccc12</smiles>

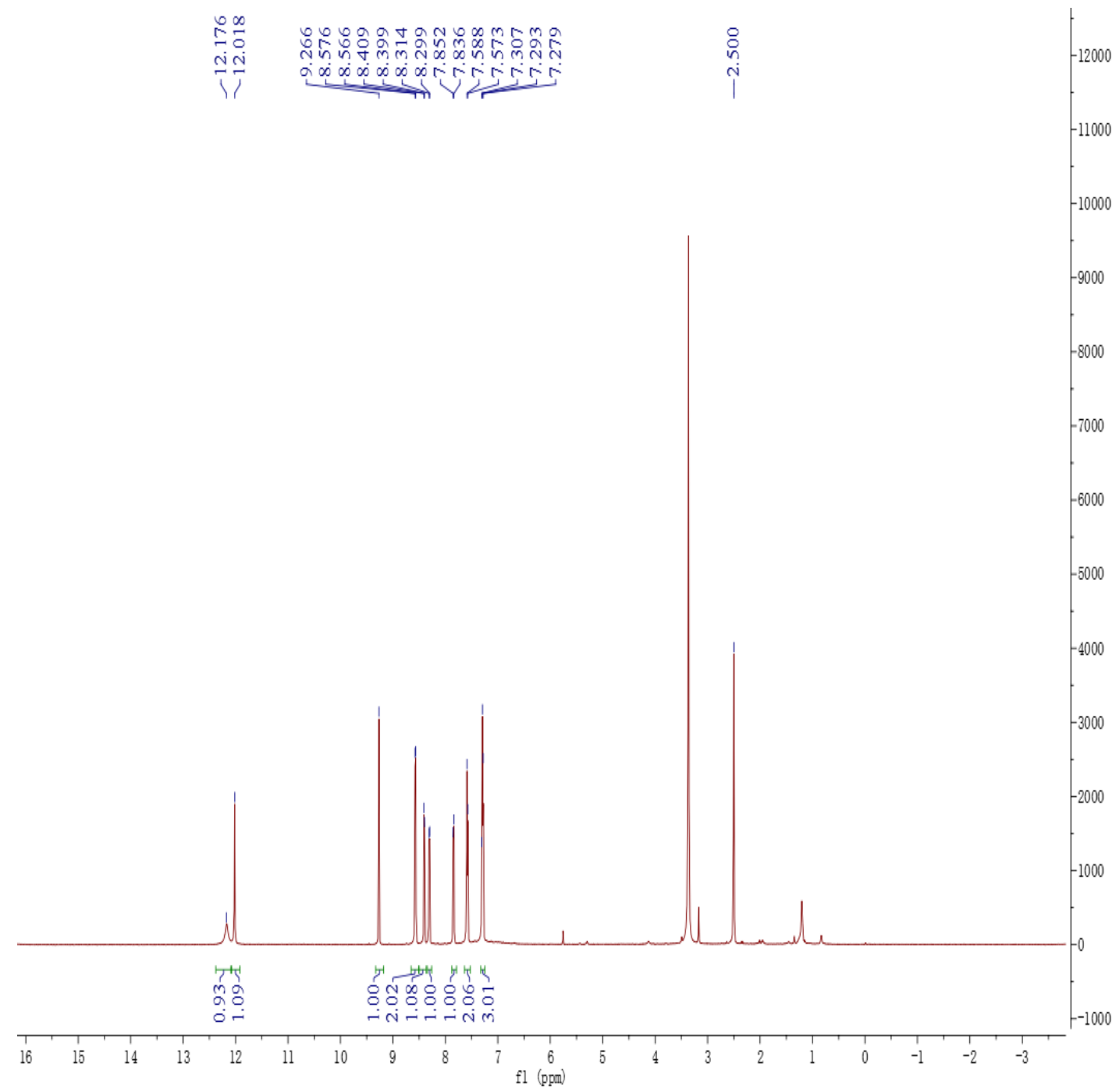

Figure S81. ${ }^{1} \mathrm{H}$ NMR spectrum of 16 in DMSO- $d_{6}(400 \mathrm{MHz})$ 
<smiles>O=C(c1c[nH]c2ccccc12)c1nccc2c1[nH]c1ccccc12</smiles>

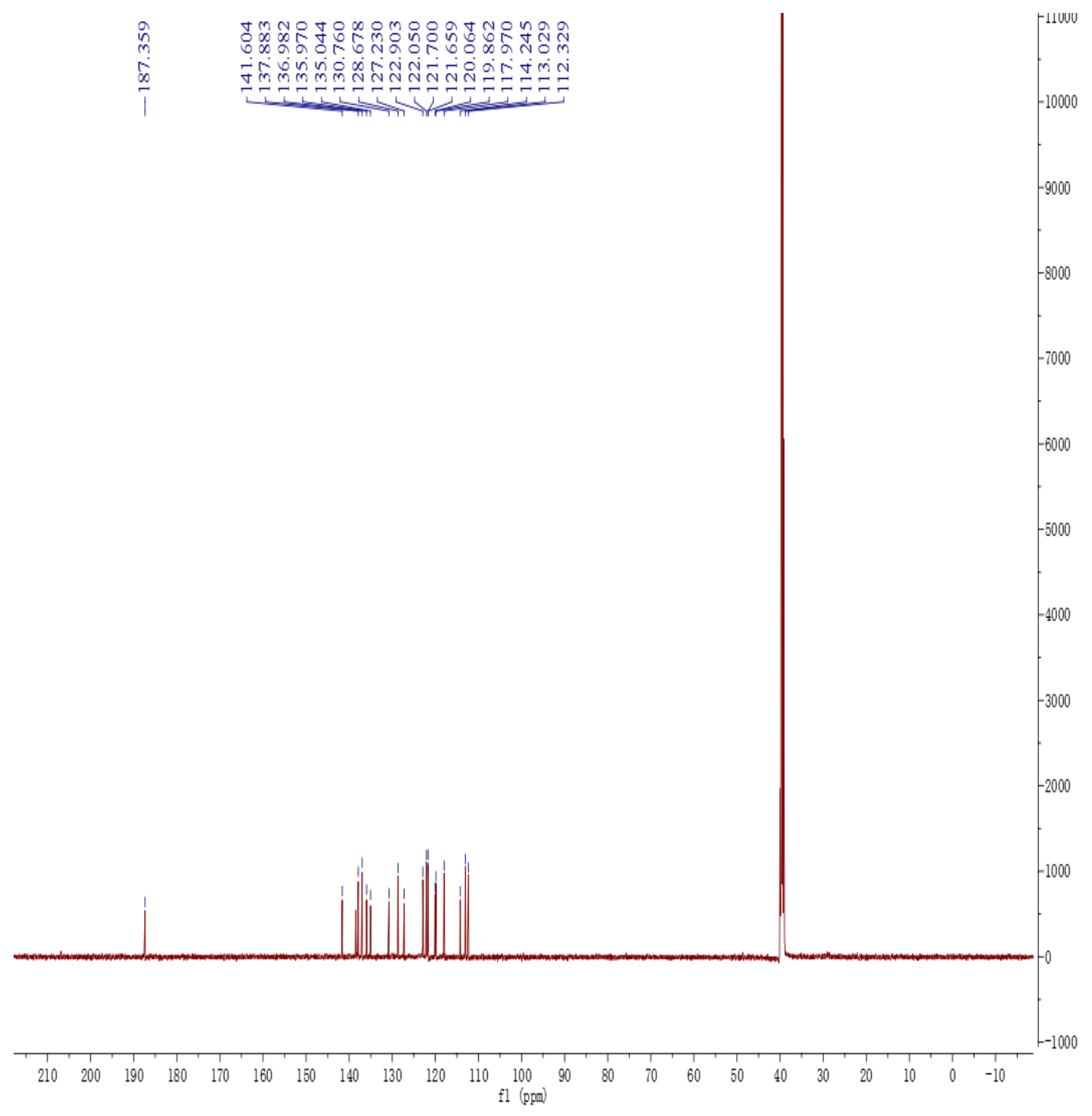

Figure S82. ${ }^{13} \mathrm{C}$ NMR spectrum of $\mathbf{1 6}$ in DMSO- $d_{6}(100 \mathrm{MHz})$ 

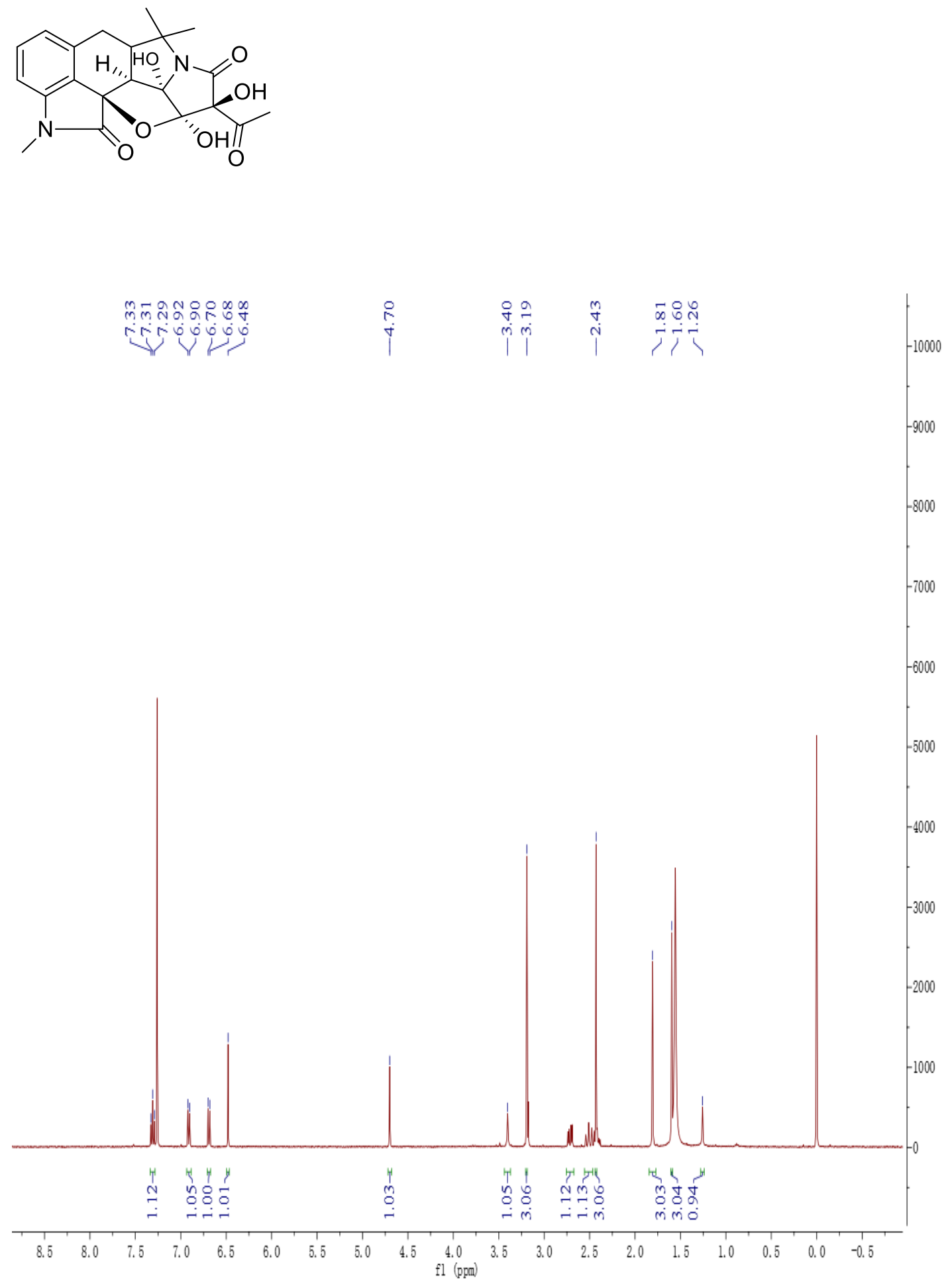

Figure S83. ${ }^{1} \mathrm{H}$ NMR spectrum of speradine $\mathrm{F}$ in $\mathrm{CDCl}_{3}(400 \mathrm{MHz})$ 


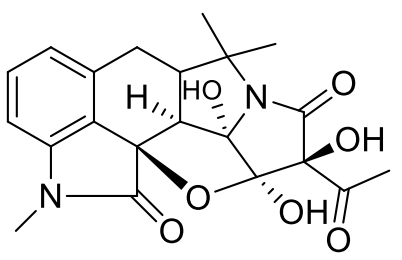

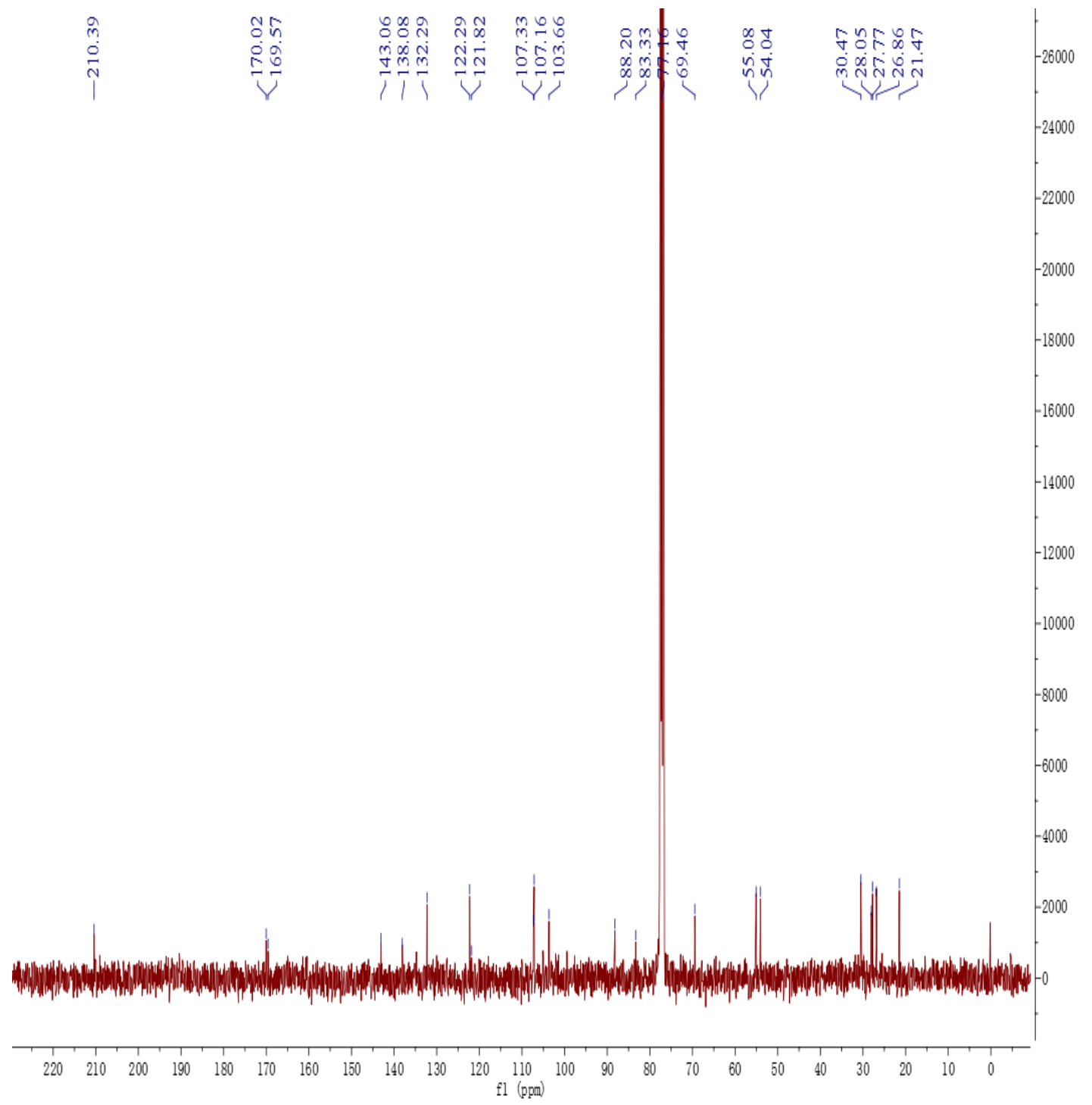

Figure S84. ${ }^{13} \mathrm{C}$ NMR spectrum of speradine $\mathrm{F}$ in $\mathrm{CDCl}_{3}(100 \mathrm{MHz})$ 
<smiles>COC(=O)Cc1c(Cc2c[nH]c3ccccc23)[nH]c2ccccc12</smiles>

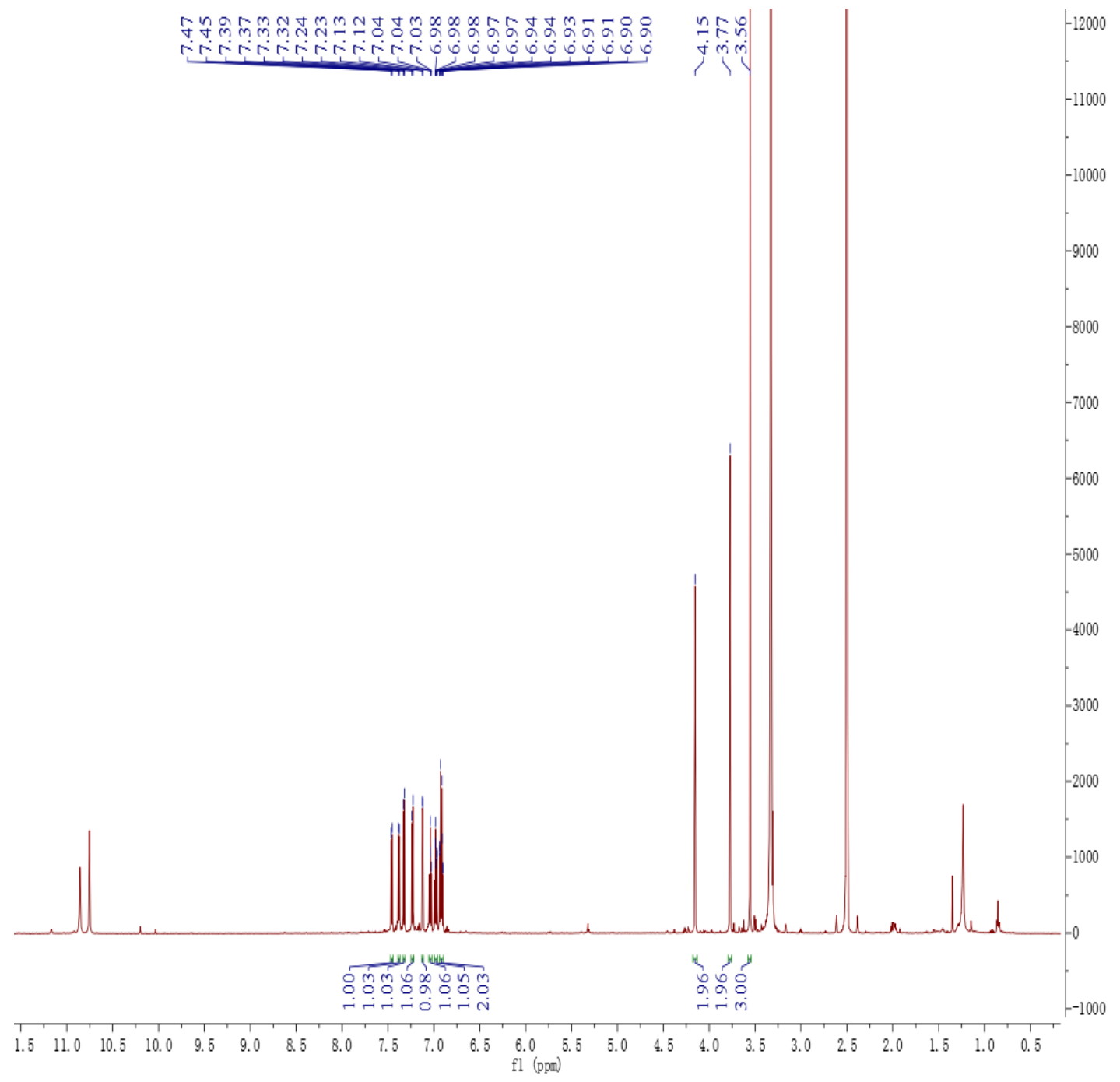

Figure S85. ${ }^{1} \mathrm{H}$ NMR spectrum of 2-(1H-indole-3-ylmethyl)-1H-3-indole-acetic acid methyl ester in DMSO- $d_{6}(400 \mathrm{MHz})$ 
<smiles>COC(=O)Cc1c(Cc2c[nH]c3ccccc23)[nH]c2ccccc12</smiles>

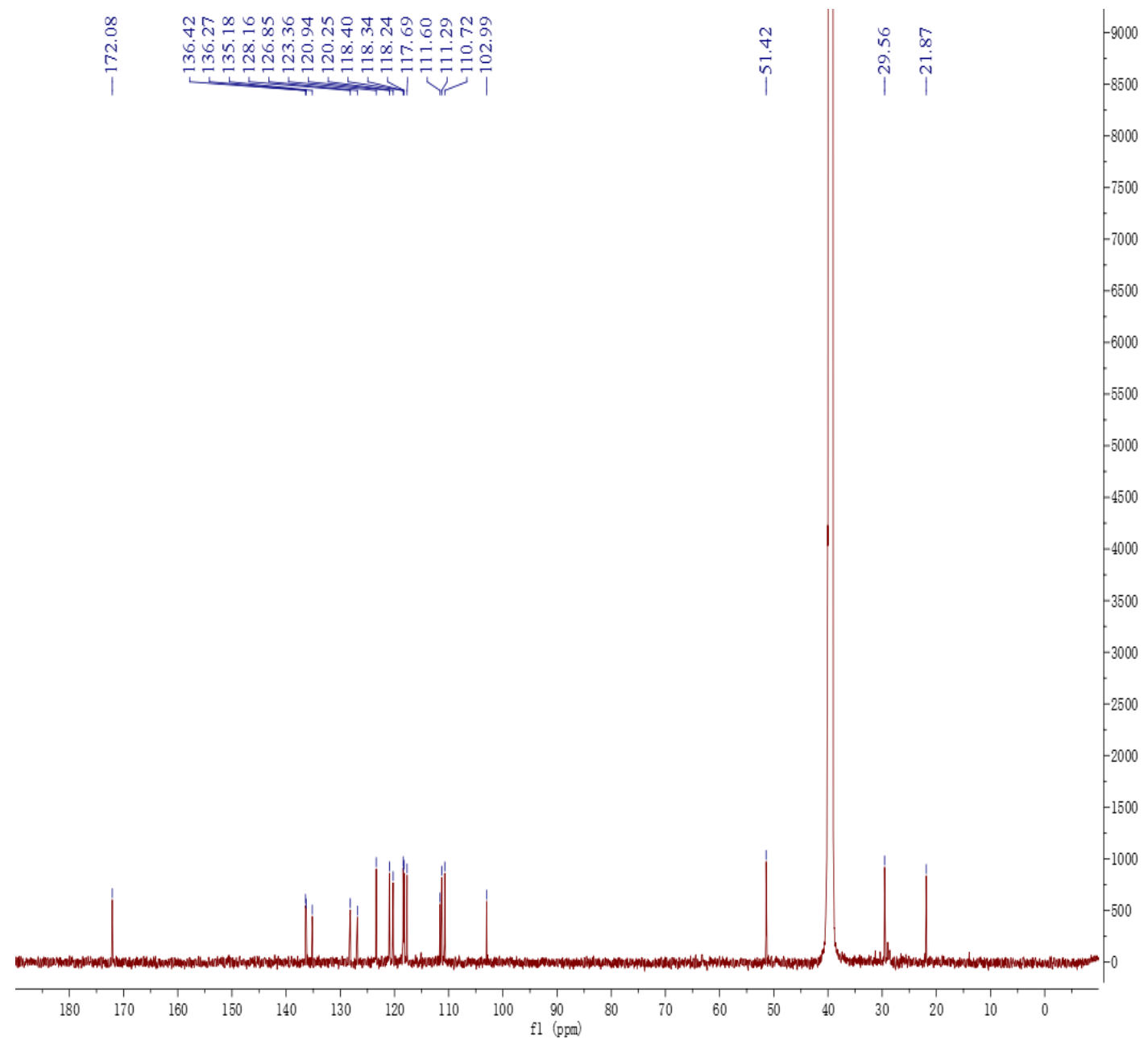

Figure S86. ${ }^{13} \mathrm{C}$ NMR spectrum of 2-(1H-indole-3-ylmethyl)-1H-3-indole-acetic acid methyl ester in DMSO- $d_{6}(100 \mathrm{MHz})$ 
<smiles>O=C1N[C@H](Cc2c[nH]c3ccccc23)C(=O)N[C@@H]1Cc1ccccc1</smiles>

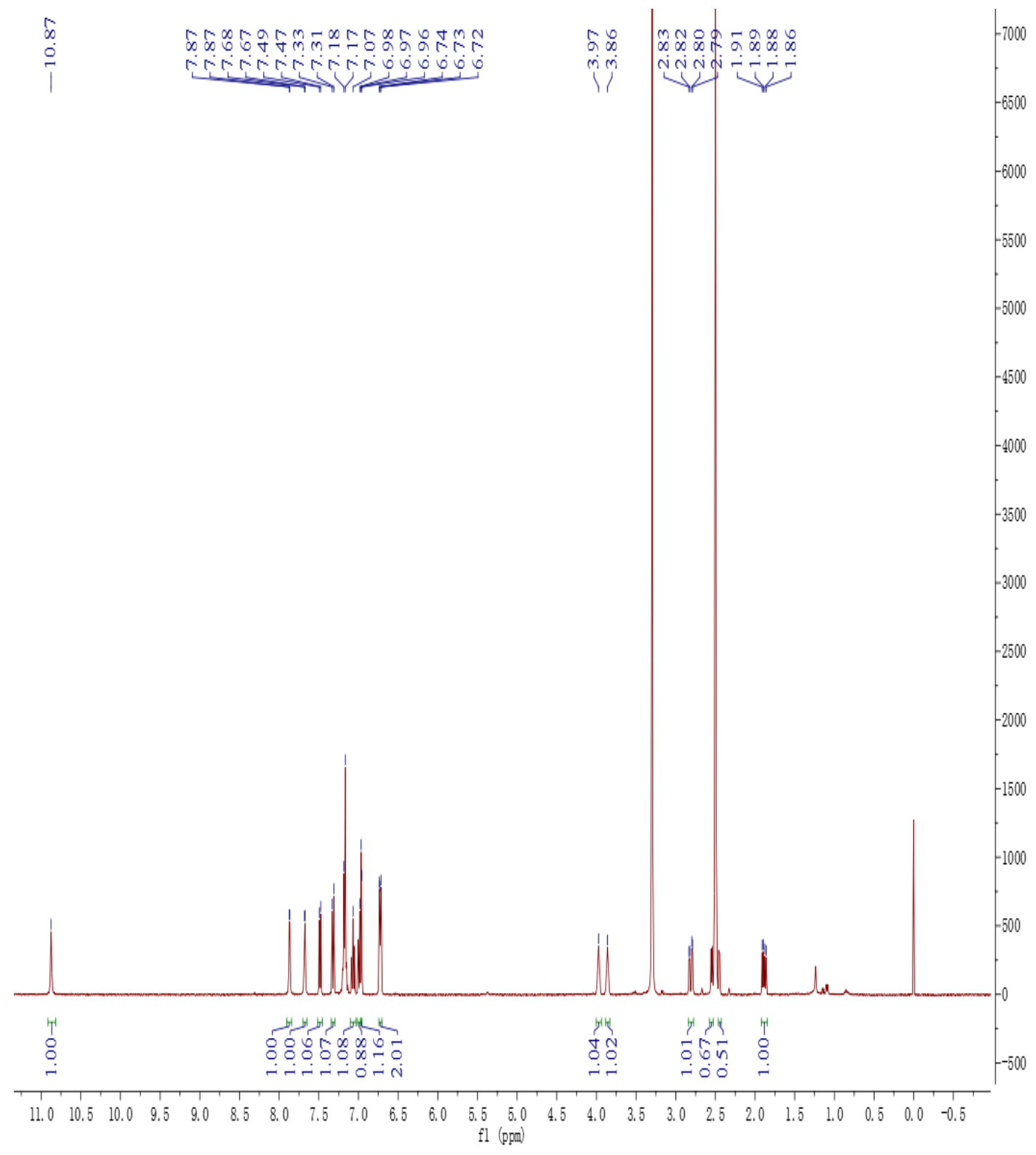

Figure S87. ${ }^{1} \mathrm{H}$ NMR spectrum of cyclo-(L-tryptophyl-L-phenylalanyl) in DMSO- $d_{6}$ (400 $\mathrm{MHz})$ 
<smiles>O=C1N[C@H](Cc2c[nH]c3ccccc23)C(=O)N[C@@H]1Cc1ccccc1</smiles>

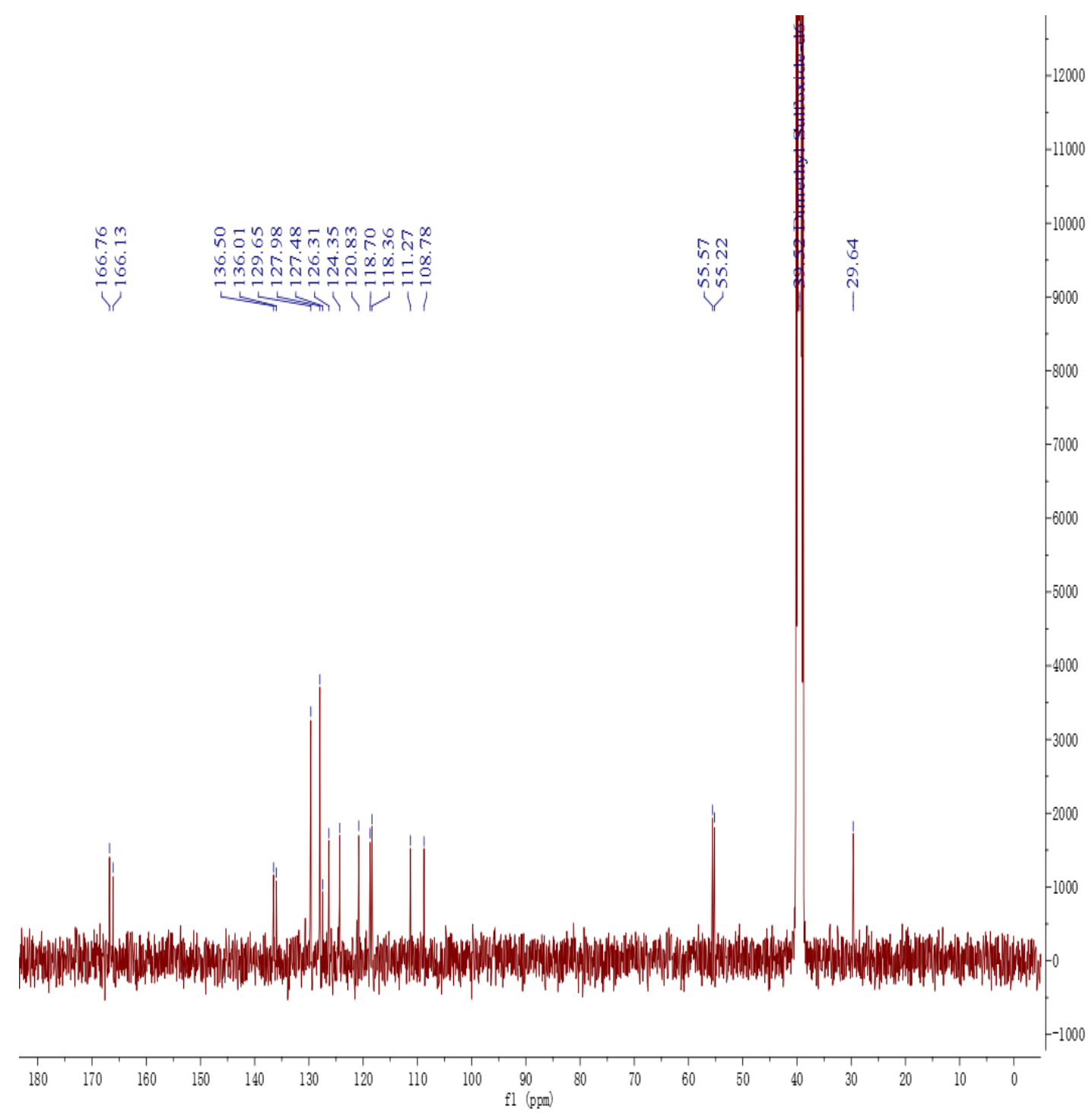

Figure S88. ${ }^{13} \mathrm{C}$ NMR spectrum of cyclo-(L-tryptophyl-L-phenylalanyl) in DMSO- $d_{6}(100$ $\mathrm{MHz}$ 
<smiles>O=C1NC(=O)[C@H](Cc2c[nH]c3ccccc23)N1</smiles>

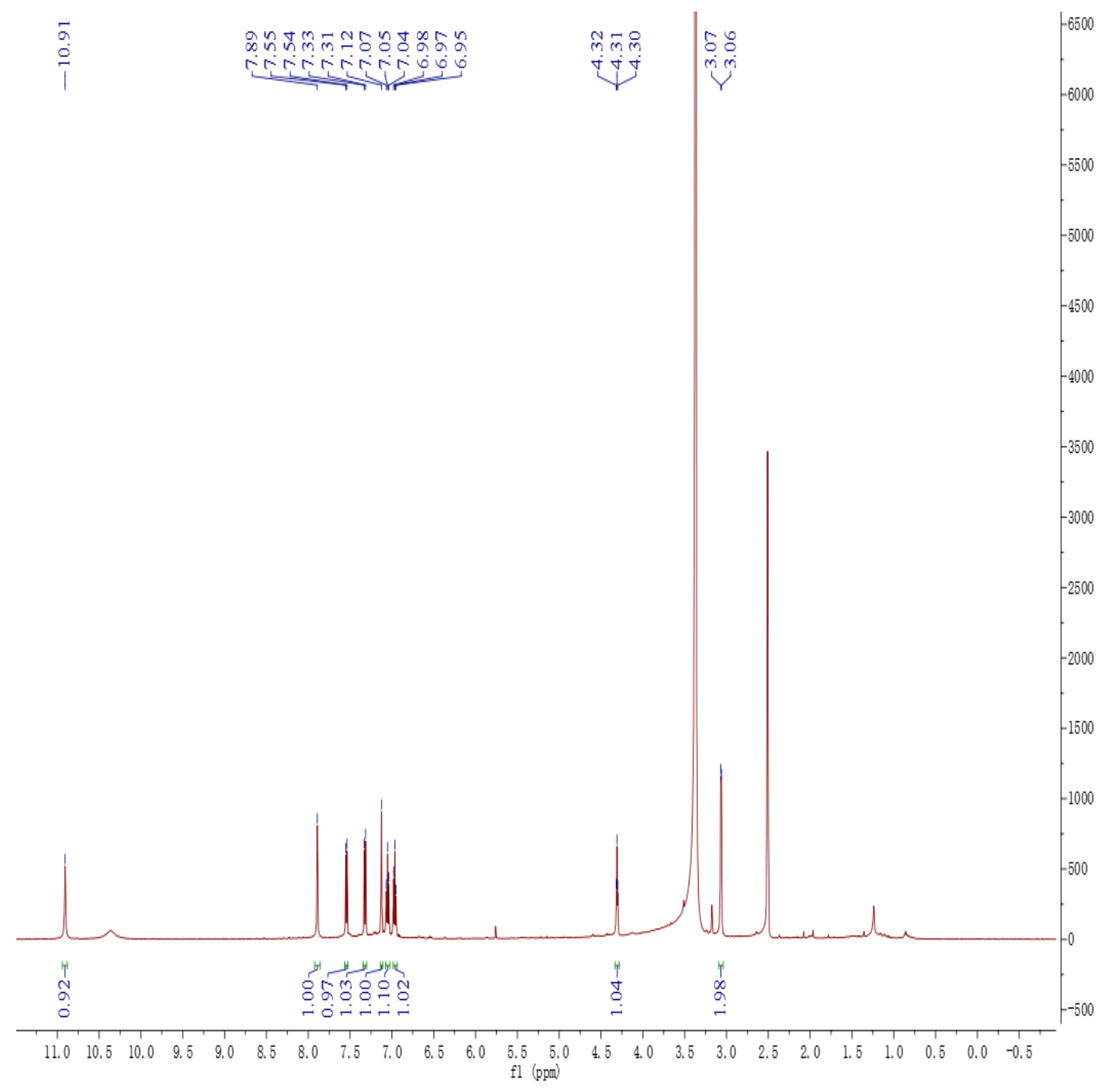

Figure S89. ${ }^{1} \mathrm{H}$ NMR spectrum of 5-(1H-indol-3-ylmethyl)imidazolidine-2,4-dione in DMSO- $d_{6}(400 \mathrm{MHz})$ 
<smiles>O=C1NC(=O)[C@H](Cc2c[nH]c3ccccc23)N1</smiles>

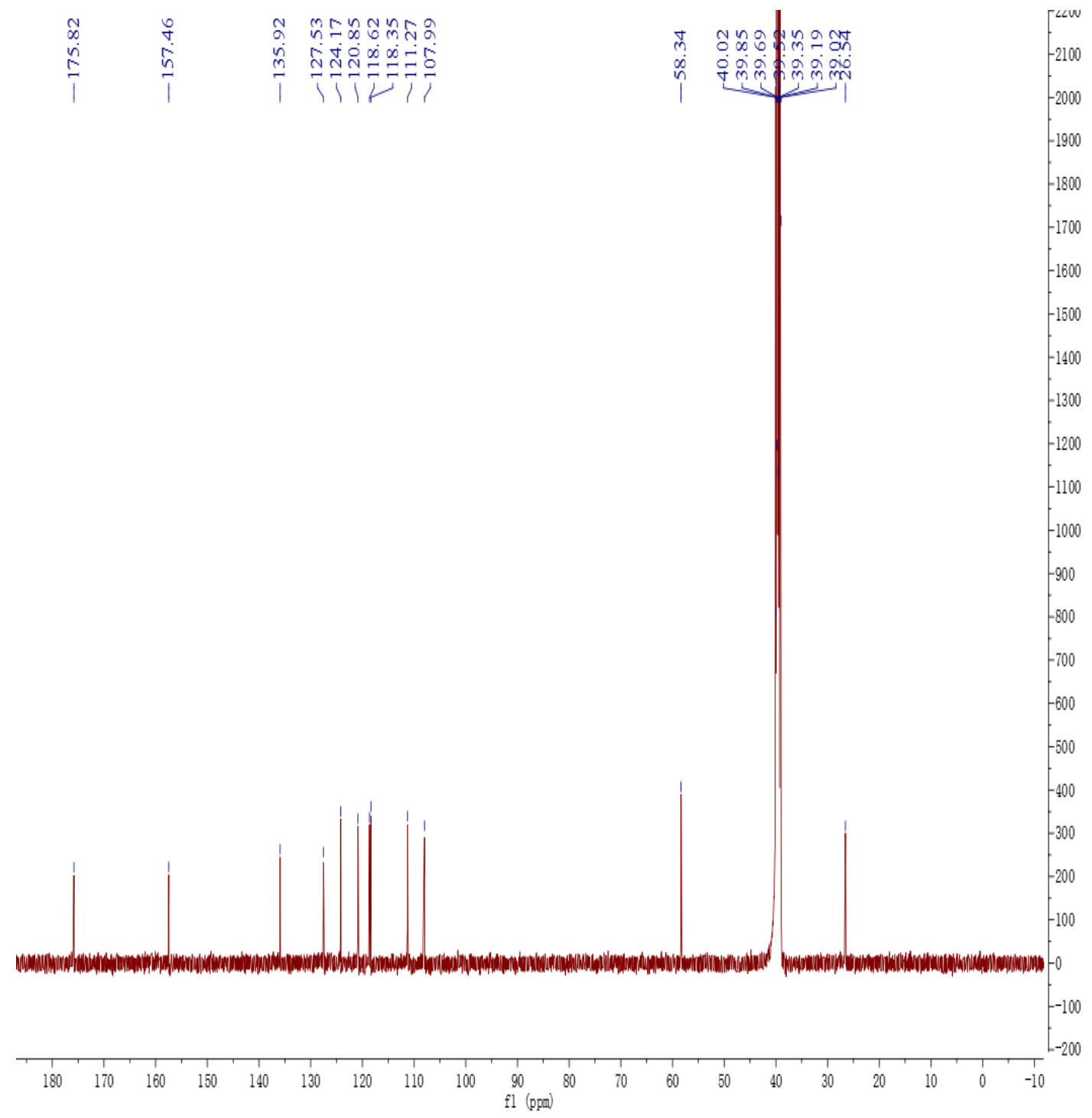

Figure S90. ${ }^{13} \mathrm{C}$ NMR spectrum of 5-(1H-indol-3-ylmethyl)imidazolidine-2,4-dione in DMSO- $d_{6}(100 \mathrm{MHz})$ 
<smiles>CC(=O)c1nccc2c1[nH]c1ccccc12</smiles>

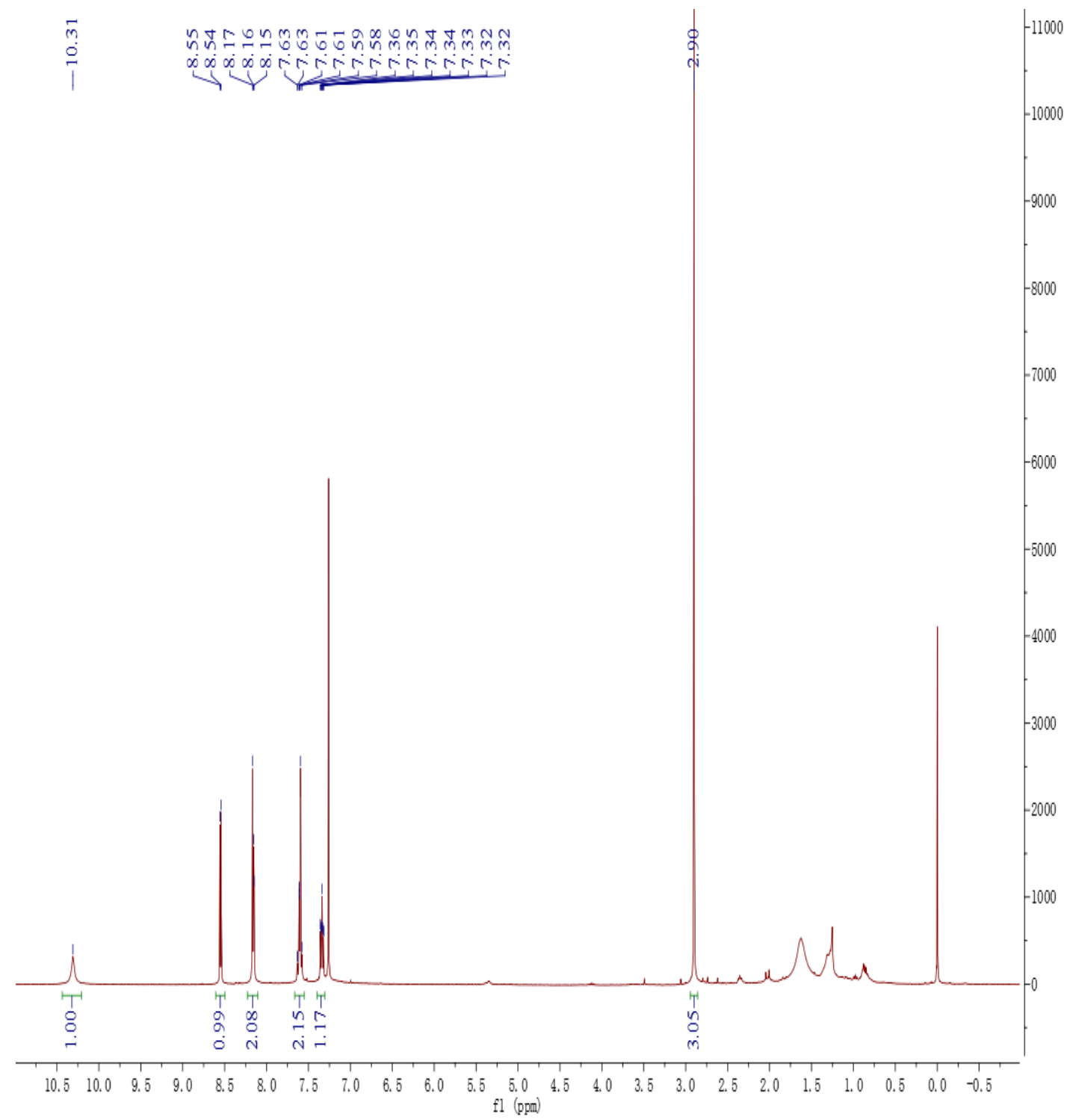

Figure S91. ${ }^{1} \mathrm{H}$ NMR spectrum of 1 -acetyl- $\beta$-carboline in $\mathrm{CDCl}_{3}(400 \mathrm{MHz})$ 
<smiles>CC(=O)c1nccc2c1[nH]c1ccccc12</smiles>

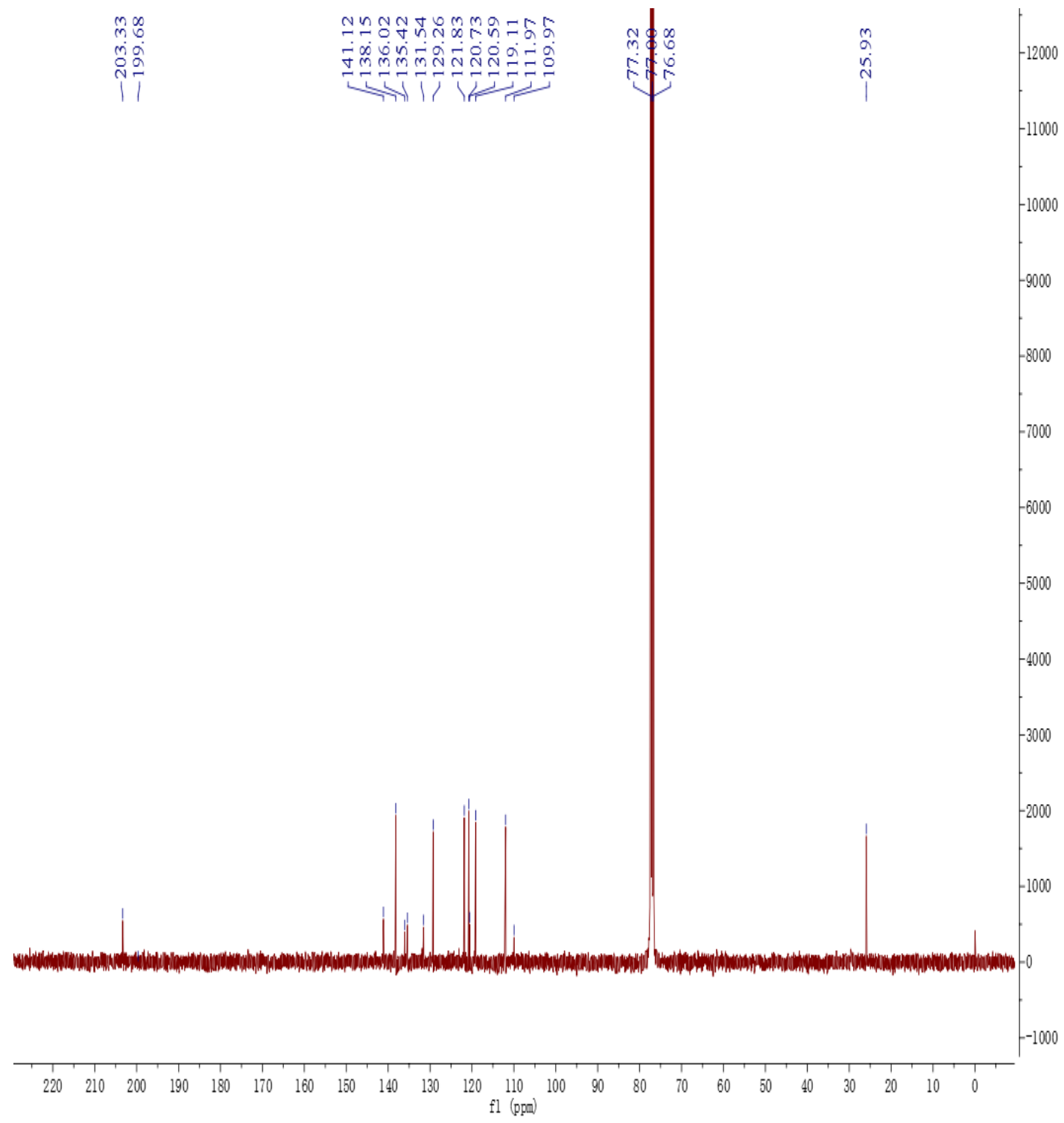

Figure $\mathrm{S} 92 .{ }^{13} \mathrm{C}$ NMR spectrum of 1 -acetyl- $\beta$-carboline in $\mathrm{CDCl}_{3}(100 \mathrm{MHz})$ 
<smiles>OCc1ccc(-c2nccc3c2[nH]c2ccccc23)o1</smiles>

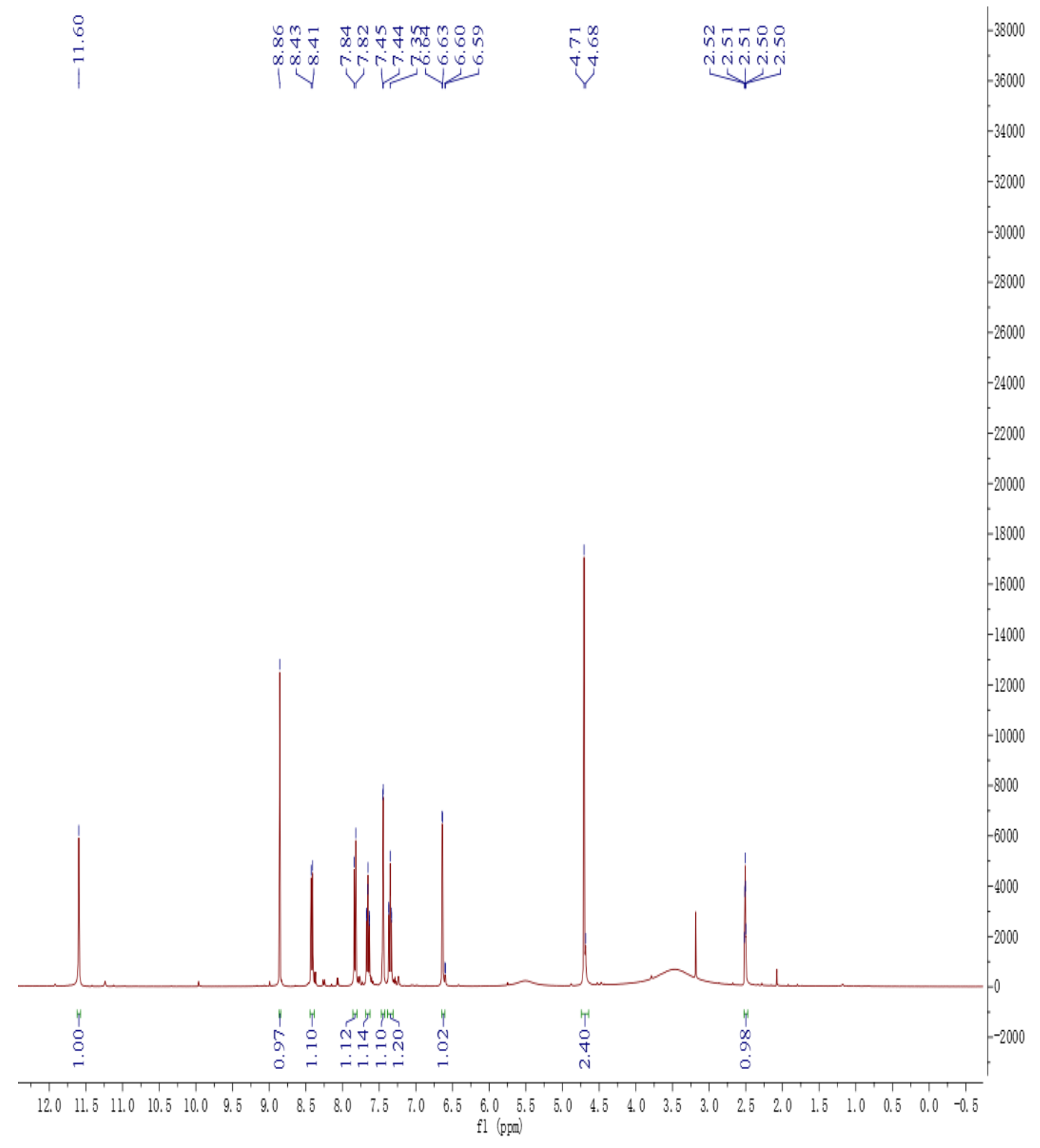

Figure S93. ${ }^{1} \mathrm{H}$ NMR spectrum of perlolyrin in DMSO- $d_{6}(400 \mathrm{MHz})$ 
<smiles>OCc1ccc(-c2nccc3c2[nH]c2ccccc23)o1</smiles>

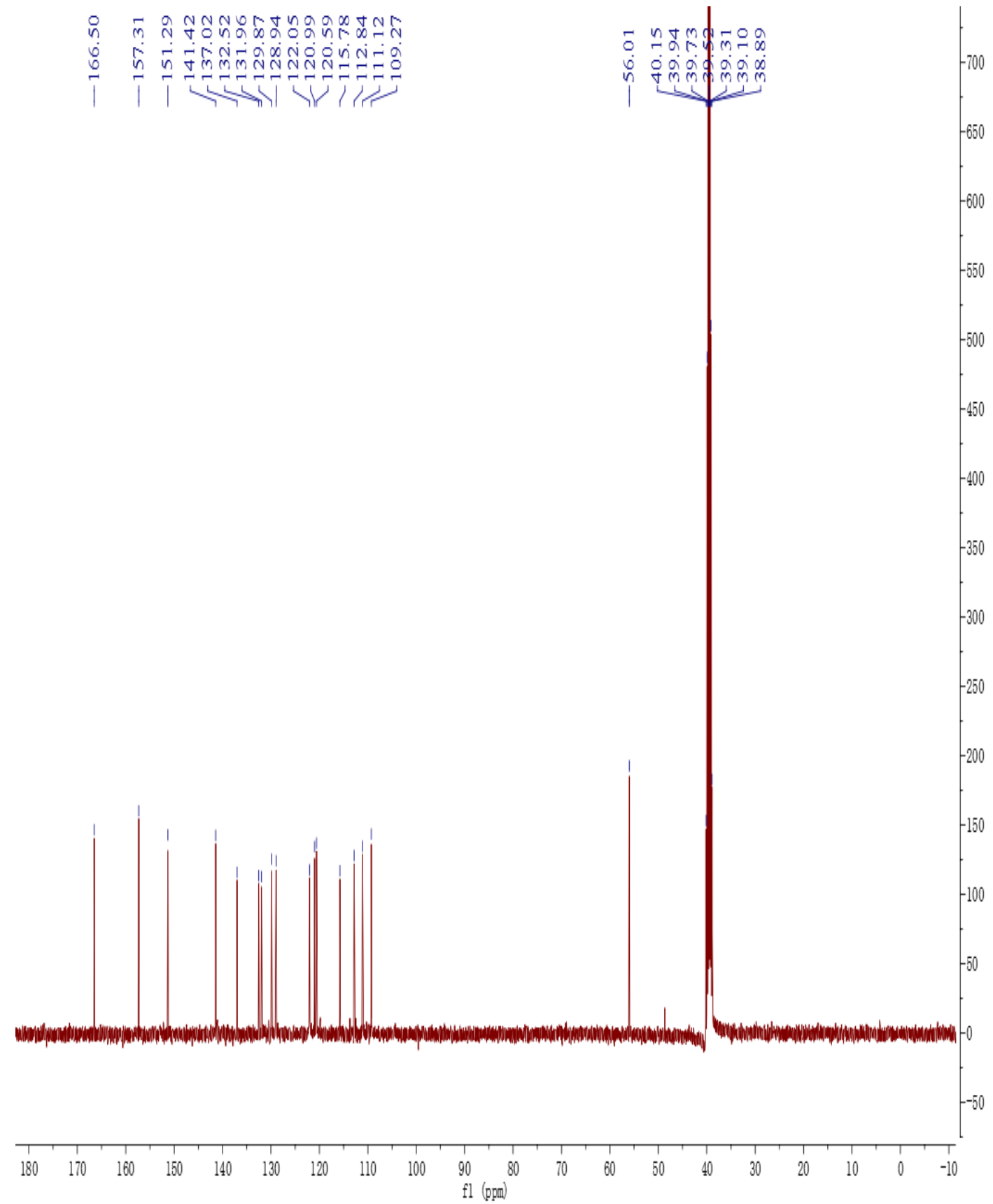

Figure S94. ${ }^{13} \mathrm{C}$ NMR spectrum of perlolyrin in DMSO- $d_{6}(100 \mathrm{MHz})$ 

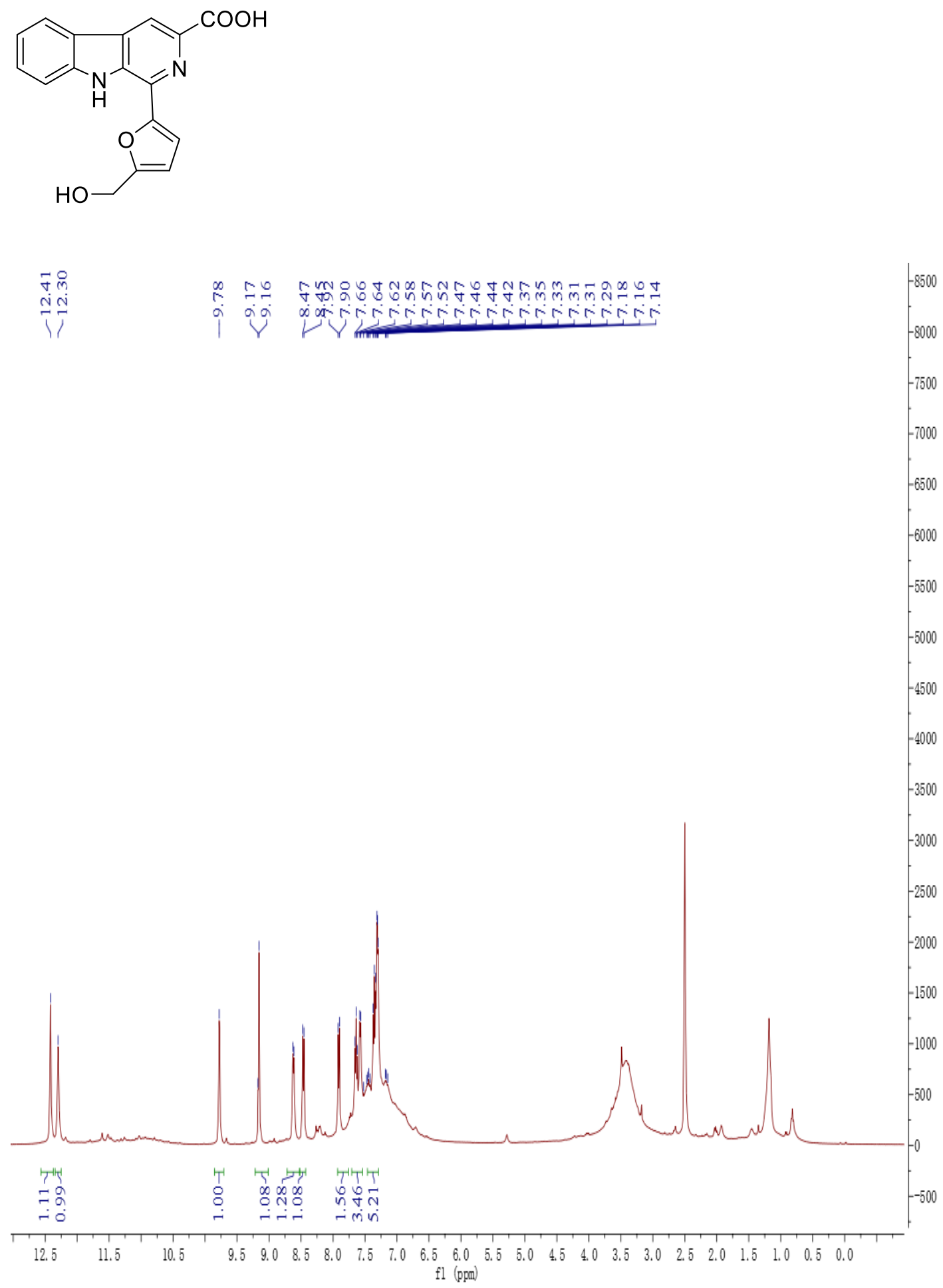

Figure S95. ${ }^{1} \mathrm{H}$ NMR spectrum of flazin in DMSO- $d_{6}(400 \mathrm{MHz})$ 
<smiles>O=C(O)c1cc2c([nH]c3ccccc32)c(-c2ccc(CO)o2)n1</smiles>

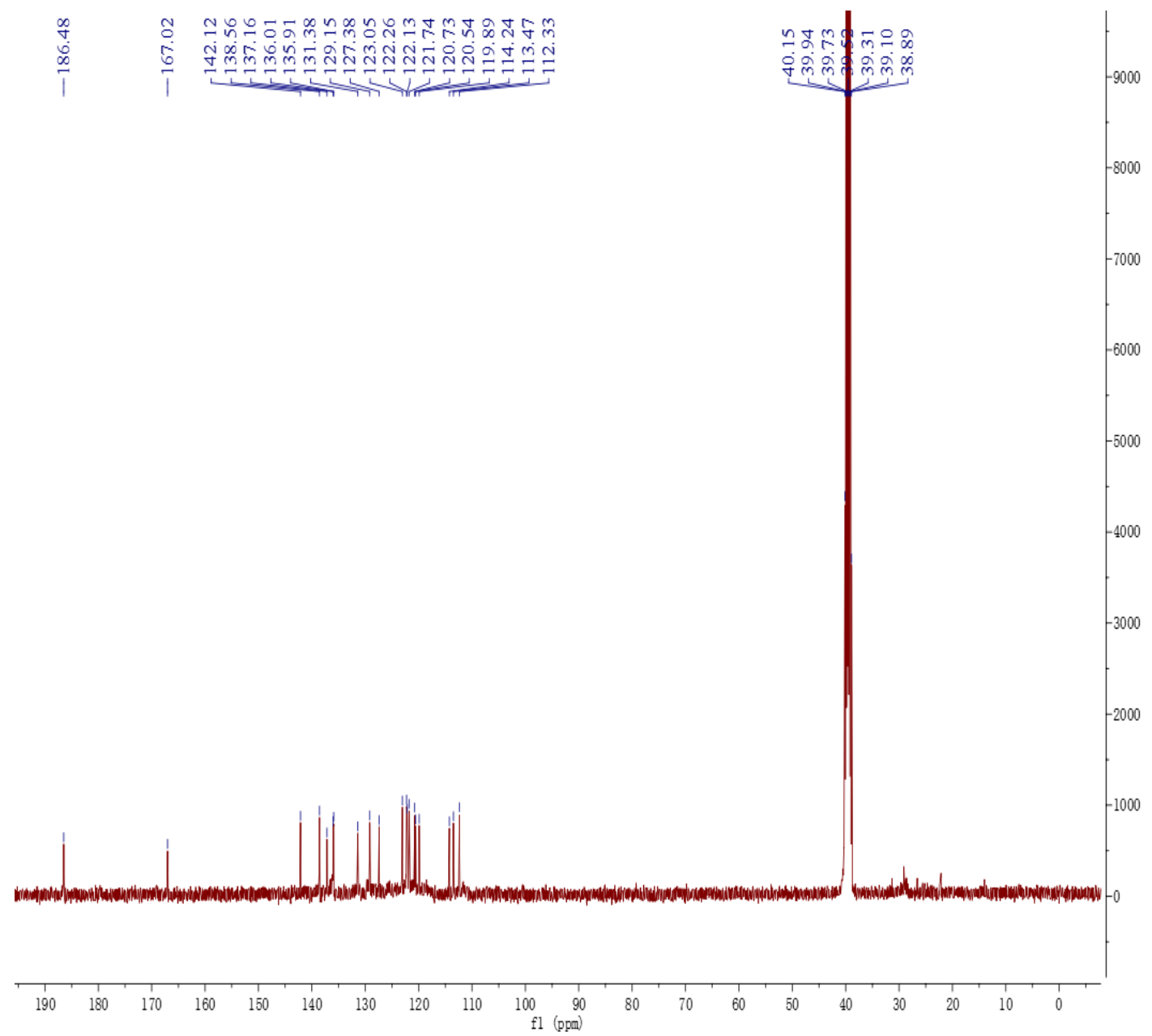

Figure S96. ${ }^{13} \mathrm{C}$ NMR spectrum of flazin in DMSO- $d_{6}(100 \mathrm{MHz})$ 


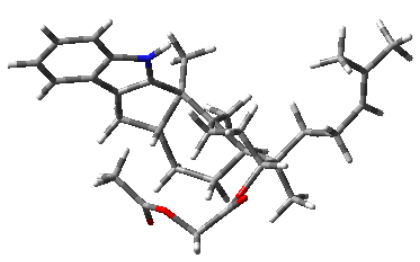

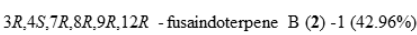

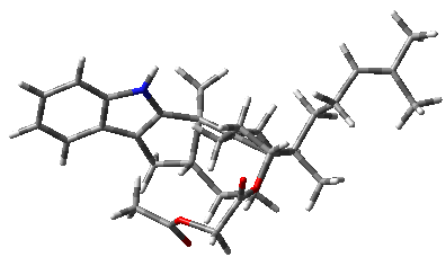

$3 R_{4} 4 S, 7 R, 8 R, 9 R, 12 R$ - fusaindoterpene $\mathrm{B}(2)-2(35.83 \%)$

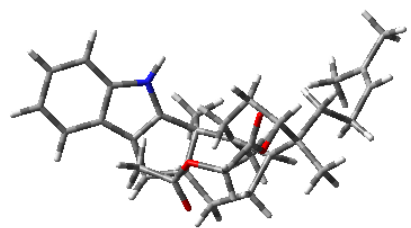

$3 R_{,} 4 S_{7}, 7,8 R_{,}, 9 R_{1} 12 R$ - fusaindoterpene $\mathrm{B}(2)-3(11.14 \%)$

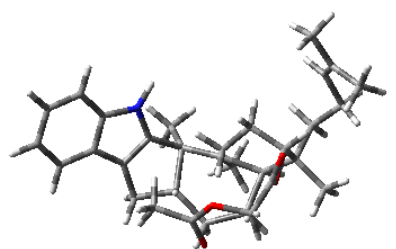

$3 R, 4 S, 7 R, 8 R, 9 R, 12 R$ - fusaindoterpene $\mathrm{B}(2)-4(5,7 \%)$

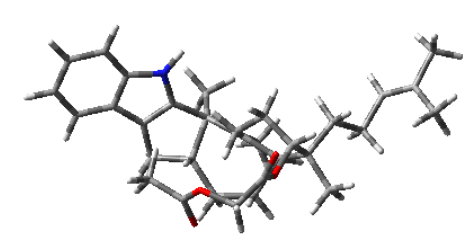

$3 R, 4 S, 7 R, 8 R, 9 R, 12 R$ - fusaindoterpene $\mathrm{B}(2)-5(2.1 \%)$

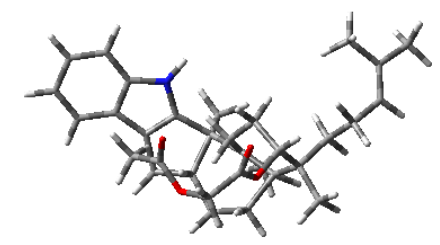

$3 R, 4 S, 7 R, 8 R, 9 R, 12 R$ - fusaindoterpene $\mathrm{B}(2)-6(2.1 \%)$

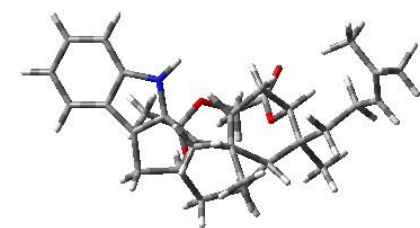

$3 S, 4 R, 7 S, 8 S, 9 S, 12 . S$ - fusaindoterpene B (2) -1 (54.57\%)

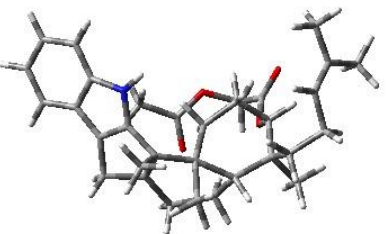

$3 S, 4 R, 7 S, 8 S, 9 S, 12 S$ - fusaindoterpene B (2) $-4(7.03 \%)$

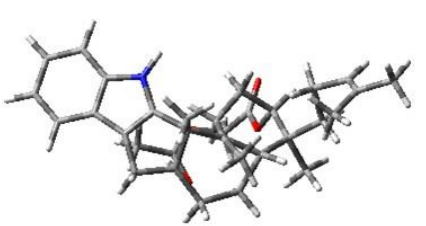

$3 S, 4 R, 7 S, 8 S, 9 S, 12 S$ - fusaindoterpene B (2) $-2(14.33 \%)$

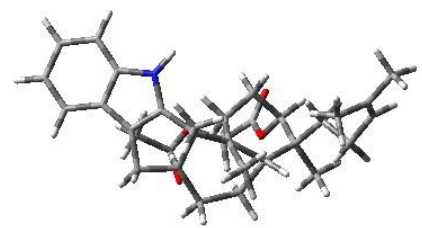

$3 S, 4 R, 7 S, 8 S, 9 S, 12 S$ - fusaindoterpene B (2) $-3(14.15 \%)$

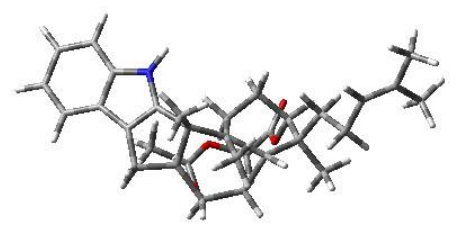

$3 S, 4 R, 7 S, 8 S, 9 S, 12 S$ - fusaindoterpene B (2) $-5(6.89 \%)$

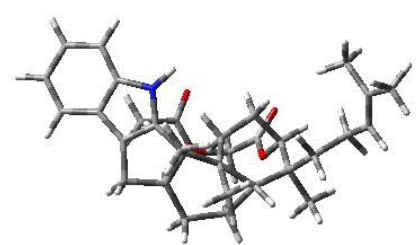

$3 S, 4 R, 7 S, 8 S, 9 S, 12 S$ - fusaindoterpene B (2) $-6(2.72 \%)$

Figure S97. The optimized conformers and equilibrium populations of $\mathbf{2}$ 

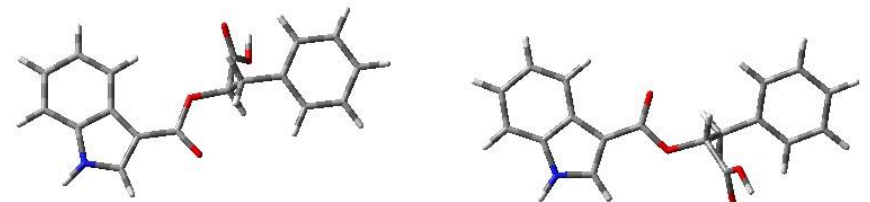

$9 R$ - fusariumindole C (5) -2 (21.75\%)

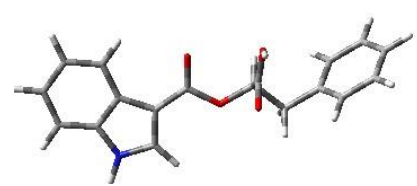

$9 R$ - fusariumindole C (5) -4 (15.78\%)

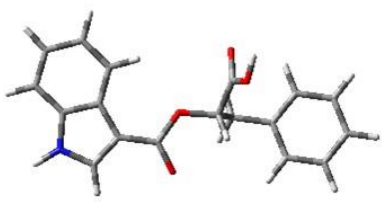

$9 S$ - fusariumindole C (5) -1 (23.23\%)

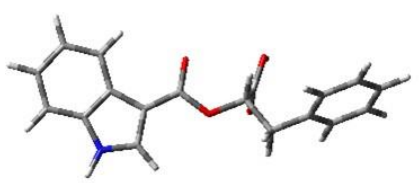

$9 S$ - fusariumindole C (5) -4 (15.93\%)

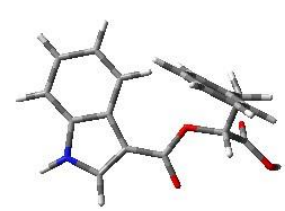

$9 R$ - fusariumindole C (5) -5 (10.89\%)

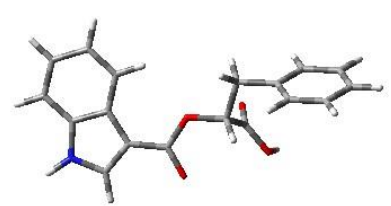

$9 R$ - fusariumindole C (5) -3 (16.92\%)

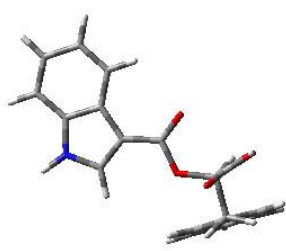

$9 R$ - fusariumindole C (5) -6(10.89\%)

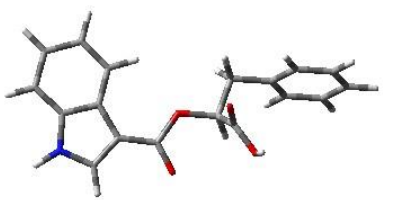

$9 S$ - fusariumindole C (5) -3 (16.23\%)

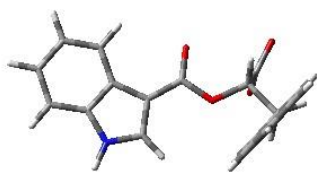

$9 S$ - fusariumindole C (5) -6 (11.53\%)

Figure S98. The optimized conformers and equilibrium populations of 5 